University of Latvia

Faculty of Business, Management and Economics

\title{
Journal of Economics and Management Research
}

Founded in 2001

as Acta Universitatis Latviensis, series

"Economics. Business Administration"

Volume 7 
Journal of Economics and Management Research, Volume 7.

Riga: University of Latvia, 2018, 114 pages.

The Journal of Economics and Management Research is an interdisciplinary scientific journal in the field of economics, business management, national economy, structural and social policies, innovation perspectives and institutional capability.

The Journal of Economics and Management Research, a Scientific Journal of the University of Latvia, is published once per year.

\section{General Editor - Prof. Dr. Viesturs Pauls Karnups}

\section{EDITORIAL BOARD}

Prof. Dr. Signe Bāliņa, University of Latvia

Prof. Dr. Jean David Avenel, Paris-Est Creteil (Val de Marne) University (France)

Assoc. Prof. Dr. Džineta Dimante, University of Latvia

Prof. Dr. Gundars Kaupins, Boise State University (USA)

Prof. Dr. Natalia Kuznetsova, St. Petersburg University (Russia)

Prof. Dr. Kristina Levišauskaitè, Vytautas Magnus University (Lithuania)

Prof. Dr. Barry Lesser, Dalhousie University (Canada)

Prof. Dr. Nikolay Nenovsky, University of Picardie Jules Verne (France)

Prof. Dr. Josef Neuert, University of Applied Sciences Kufstein (Austria)

Prof. Dr. Tiiu Paas, Tartu University (Estonia)

Prof. Dr. Gunnar Prause, TSEBA/Tallinn University of Technology (Estonia)

Prof. Dr. Arild Sæther, Agder Academy of Sciences and Letters (Norway)

Prof. Dr. Bruno Sergi, Messina University (Italy)

Prof. Dr. Biruta Sloka, University of Latvia

Prof. Dr. Baiba Šavrina, University of Latvia

Prof. Dr. Ligita Šimanskienè, Klaipeda University (Lithuania)

Prof. Dr. Ērika Šumilo, University of Latvia

Assoc. Prof. Dr. Kamil Zajackowski, University of Warsaw (Poland)

Assoc. Prof. Gundars Bērziņš, University of Latvia

Prof. Dr. Margarita Dunska, University of Latvia

Journal is available:

http://www.lu.lv/apgads/izdevumi/elektroniskie-izdevumi/

zurnali-un-periodiskie-izdevumi/journal-of-economics-and-management-research/

Layout: Andra Liepina

Cover design: Agris Dzilna

ISSN 2255-9000

(C) University of Latvia, 2018

DOI: http://doi.org/10.22364/jemr.7 


\section{TABLE OF CONTENTS}

From the Editor

Kristīna Bojāre, Kristīne Petrovska

WHY BANKS CHOOSE TO TAKE EXCESSIVE RISK

THAT LEADS TO DANGEROUS OUTCOMES?

Diāna Arāja, Jānis Priede

OPPORTUNITIES FOR ASSESSMENT OF HEALTH CARE SYSTEM'S EFFICIENCY:

THREE-LEVELS EVALUATION MODEL

Zanda Dāvida

CHARACTERISTICS OF CONSUMER PROTECTION AND

PUBLIC MANAGEMENT IN LATVIA

Laura Keršule

EMPLOYEE ENGAGEMENT ANALYSIS EVALUATION APPROACHES, RESULTS AND CHALLENGES

Laimdota Komare

DETERMINANTS OF TOTAL FACTOR PRODUCTIVITY

IN EIGHT EUROPEAN COUNTRIES

Julia Liodorova, Valeriya Fursova

FORENSIC ACCOUNTING IN THE WORLD:

PAST AND PRESENT

Ineta Lakstigala, Signe Balina

CURRENT APPROACHES TO PUBLIC ADMINISTRATION

EMPLOYEE EVALUATION 



\section{FROM THE EDITOR}

Dear Reader,

This is the issue for 2018 and we expect to be able to publish the next issue in December 2019.

Most of the authors are $\mathrm{PhD}$ students and we encourage articles from both established academics, as well as prospective academics.

For past and future authors the good news is that we have finally been added to the EBSCO database system. The journal can be found in the EBSCO Business Source Complete database. Fortunately, all past issues have also been included (i. e., 1-6).

We hope you enjoy this issue and are looking forward to the next issue.

Best wishes

\section{Viesturs Pauls Karnups}

General Editor 


\title{
WHY BANKS CHOOSE TO TAKE EXCESSIVE RISK THAT LEADS TO DANGEROUS OUTCOMES?
}

\author{
KRISTĪNA BOJĀRE \\ KRISTĪNE PETROVSKA
}

\begin{abstract}
Banks are fundamental in increasing competitiveness of small, open economies that have underdeveloped capital markets. However, when the same banks are encountered by the wrong incentives that lead to excessive risk taking the resulting outcomes are not only ruinous for their shareholders, but are also capable of disrupting the entire financial stability, even endangering regional economies. This article centres on both the institution specific internal governance related incentives for excessive risk taking and systemic incentives. In small, open economies, the most notable examples of the former category are weak internal control functions or poorly informed and insufficiently trained senior management, and inadequate compensation schemes. Systemic incentives for excessive risk taking, on the other hand, are arising from the specificities of legislative and regulatory framework and actions of external agents such as herding behaviour by peer-banks, biased bail out possibilities and regulatory arbitrage issues, high tolerance level of depositors and legislative deficiencies (limited liability of banks, tax shields for corporate debt). This article also looks at the resulting outcomes from excessive risk taking - whether the risk taking increased the shareholder value and what are the effects for the financial stability, direct and indirect costs to the taxpayers and local economy as a whole. The issues shown in this article are crucial for further development of the regulation for the banking sector, as well as for making future investment related decisions and formulation of banks' risk appetite frameworks. The analysis in the article is conducted by statistical and market analysis, literature review, document examination of prudential and supervisory regulation.
\end{abstract}

Key words: Latvia, systemic risk, bank risk incentives, economic agents, prudential regulation

JEL code: G21, G28, G41

\section{INTRODUCTION}

Banks normally act as pivotal financial intermediaries in economy. Therefore, their role should be accounted for when identifying financial soundness and stability of the country. Moreover, banks are particularly crucial in small and open economies for ensuring economic activities, financial decisions and risktaking behaviour that has much larger impact on the country's financial stability. 
Banks' activities, when driven by wrong incentives from internal factors, shareholders and other interested parties, can have an impact of larger scale, especially, when capital markets are underdeveloped, and the associated risks arise in the economy. To mitigate risks of inadequate banking behaviour that threatens financial instability it is of crucial importance to address the significance of the banking sector, analyse the incentives for excessive risk taking and evaluate the possible resulting outcomes of such decisions.

The research question of this study is whether the incentives for excessing risk taking by banks themselves are leading to higher value for shareholders and overall creating a justified and prudent systemic risk approach, given banks' own systemic importance in small, open economies with underdeveloped capital markets. The aim of this study is to identify incentives for excessive bank risk taking - both institution specific and systemic and outline the possible resulting outcomes from such decisions in the framework of small, open economy like Latvia.

\section{THE HYPOTHESIS OF THE STUDY ARE AS FOLLOWS:}

H1: The more stronger framework of corporate governance is established the more incentives of risk taking of the bank are mitigated.

H2: The inability to successfully mitigate systemic incentives for excessive risk taking in the banking sector creates vast opportunities with potentially disastrous consequences.

The methodology of the paper encompasses the content analyses of appropriate literature review, document examination of prudential and supervisory regulation, statistical and market analysis. The information sources used in the study cover inter alia journal articles, working papers, policy papers, regulator's yearly reports, financial data reports.

The novelty of this research lies in differentiating the institution specific and systemic incentives for excessive risk taking of banks in small, open economies, simultaneously assessing the resulting outcomes of such incentives. The research aims to fill the gap in the analyses of risky banking business that has disruptive outcomes given the specificities of those countries that have small and open economies with underdeveloped capital markets.

The main limitation of this research is availability of statistical data, publicly available information that allows to assess supervisors approach given bank specific riskiness in the capital market of Latvia and other factors relating to previous research in this field that stem from the differences between various economies.

The article is organised as follows - first part of the article is dealing with the importance of the banking sector in small, open economy both from the aspect of bank specific and systemic importance. Second part is devoted to the institution specific incentives while third section explores systemic incentives for excessive 
risk taking. Section four analyses resulting outcomes for excessive bank risk taking. Discussion, conclusions and proposals of the paper are addressed in the last paragraph.

\section{RESEARCH RESULTS AND DISCUSSION}

\section{IMPORTANCE OF THE BANKING SECTOR}

The very basic function of the bank is to ensure financial and risk intermediation. That also includes considering concentration aspect as banks take upon short-term liabilities, bundle them and later redistribute through lending and other financial products. However, as seen from the previous experience with the last global financial crisis, the golden rule of balance sheet is not always considered.

In small, open economies, where capital markets are often underdeveloped, one of the option for growth of the enterprises and other entities is credit financing from banks. Therefore, it is crucial for banks to lend while maintaining to be sound and stable and not to delve into excessive risk taking by wrong incentives. When banks increase their systemic importance and initiate into taking more power in the economy they can start to implement strategies to maximize their profits at the expense of the others more rapidly than they would in regular banking activities. This pattern of behaviour often occurs without any systemic background, as banks are still regular businesses that are aimed to increase shareholder wealth through many corporate governance related aspects, including risk management (Biondi and Graeff, 2017). It is in the nature of the banking business that bankers will always try to maximise their wealth at the expense of excessive risk taking (Fabricion and Brada, et al., 2012). Such behavioural pattern can be seen not only at the micro, but also at the macro level (Contributions of each institutional sector to macroeconomic developments, Eurostat).

A stable and foreseeable banking system is a foundation stone for every country, but especially for countries that have small and open economies due to previously mentioned considerations. Some of the parameters of openness that also influence the stability of the banking sector are the trade imbalances, de iure and de facto barriers to moving funds between countries. All these are closely linked with international agreements and other aspects that stem from subjection to external legislation like World Trade Organization, European Union and Euro Area. Banks are mediators towards maintaining the overall balance while being the first ones to be flushed over during capital runs.

Nowadays banks can also serve not only as financial intermediaries, but also as creators of national wealth - through supply of specialised financial services, and joint ventures with technological enterprises. These "sudden" behavioural changes are mostly seen in small, open economies with highly developed technological background like Baltics (BNN, 2016), Nordic region and Hungary (KPMG, 2017). 
As explored below on a case study of Latvia it is seen that the banking sector creates a significant part of Latvia's gross national income while employing comparatively less people in this sector - concluding that financial services sector is more productive than other sectors. As seen in figure 1 this sector in Latvia is becoming even more and more productive as the value produced increases while the share of labour force decreases.

Figure 2 shows that non-financial corporations are taking traditional debt from credit institutions (banks in the case of Latvia) to finance their needs of expansion and no other, more advanced credit sources like issued debt obligations, corporate bonds or preferred stocks.

It is worth noting that Figure 3 displays the banking sector's importance from the market specific perspective when considering individual banks. Even when the number of banks in Latvia has varied over the years, the banking market structure of individual banks is still present in the means of competitiveness.

The authors measured the banking market density by the HerfindahlHirschman Index (HHI) and concluded that Latvia's banking market can be described as lightly to moderately concentrated (Figure 3). As proposed by the methodology of United States Department of Justice (2015) the HHI between 1500 and 2500 can characterise the market as moderately concentrated, but markets with $\mathrm{HHI}$ under 1500 can be defined as lightly concentrated. This allows one to conclude that Latvian banking market is dense, and the institution specific business decisions should have an impact not only on shareholders' wealth, but also on the perspective of systemic importance as denser banking market is bound to sustain systemically important institutions.

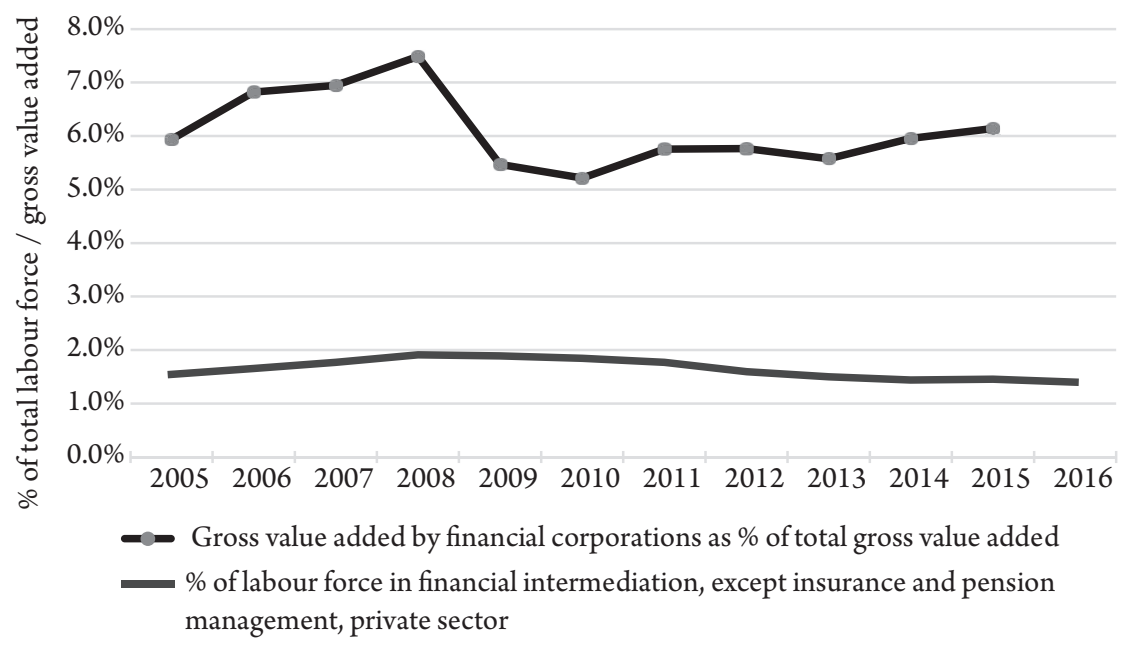

Source: Authors calculations based on data from Eurostat and Central Statistical Bureau of Latvia

Fig. 1. Productivity in the financial sector in Latvia, years 2005-2016 


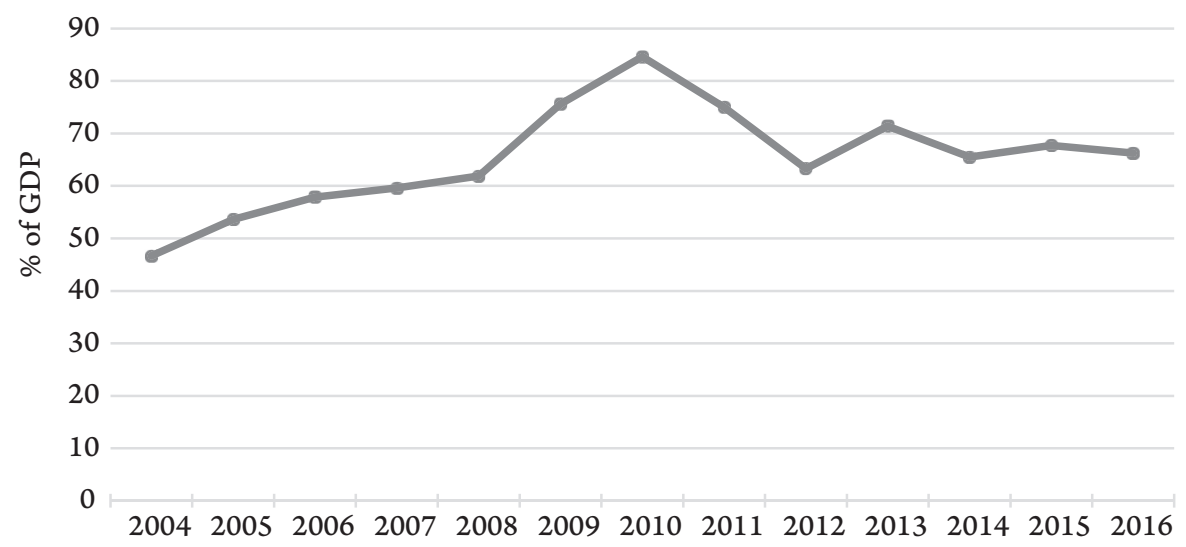

Source: European Central bank database

Fig. 2. Debt excluding trade credit of non-financial corporations as a ratio of GDP in Latvia, years 2004-2016

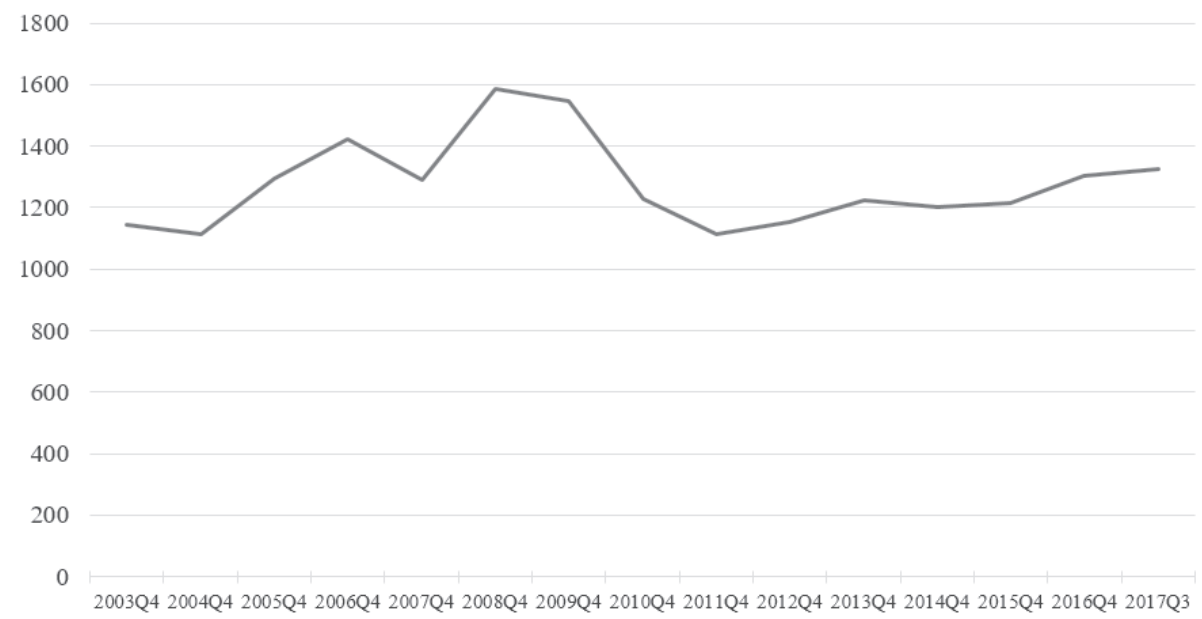

Source: Authors own calculations, the FCMC

Fig. 3. Market concentration index (HHI) by bank asset size in Latvia, years 2003Q4-2017Q3

All these figures also demonstrate the importance of banking sector in small, open economy like Latvia. Therefore, it is only reasonable to determine what are the driving factors for banks to take upon excessive risks that might not only lead to a single fall, but could steer into system wide shocks that spread through all economy not only nationally but regionally. 


\section{INSTITUTION SPECIFIC INCENTIVES}

When assessing risks, the bank specific view should be analysed from micro level. There are various factors that drive banks to acquire more risk as business evolves. These factors are similar to traditional business incentives as banks in general are still businesses that drive to foster shareholders wealth through many corporate governance related aspects such as profit, business growth and wages (Biondi and Graeff, 2017).

However, often money (or wealth) can lead to wrong incentives that may cause the shareholders to obtain false decisions that foster only business thinking which is not in the best interests of bank investors - depositors, who are mostly not with proper knowledge of financial economics. The agency theory enlightens this problem even more as the members of the management body - the main administrative and business steering body - often does not act with duty of loyalty than they should be acting according to international corporate governance principles (BCBS guidelines on the corporate governance principles for banks, 2015). This aspect also highlights the problems related to investor protection.

Because for the most riskiest aspects of the banking business there is a regulatory framework that mitigates the risks that may arise from those aspects given the task of the Regulator to maintain balanced systemic risks to protect not only the investors of the banks, but also to foster protection of minority shareholders which often balances out significant decisions of majority shareholders.

The most important regulatory framework for the banks in Europe, including Latvia, is the Capital Requirements Directive (CRD IV) (Directive 2013/36/ EU, 2013) and Regulation (CRR) (Regulation (EU) No 575/2013, 2013). Other regulatory frameworks are binding as well, but CRD IV/CRR framework should be considered as the basic framework. The authors analysed that the regulatory framework, which is applicable to banks in Europe consists of major blocks that explains the focus of supervisory expectations. For example, Supervisory Review and Evaluation Process (SREP) constitutes of four elements - business model, governance and risk, capital and liquidity aspects - all that are accounted for prudent management of the banking businesses (ECB, 2016).

Regulatory aspects previously mentioned allow the authors to conclude, firstly, that mostly the decisions of majority shareholders are those that matter the most in every bank decisions (Chen and Lin, 2015; Luo and Li, et al., 2015). Bankers will always try to maximize their wealth at the expense of excessive risk whether in risky assets that generally guarantees higher returns in short time period or in other profit generating aspects that are considered appropriate by the bankers themselves (Fabricio and Brada, et al., 2012). These decisions stem from the business model choices and closely correlate with internal aspects operating strategy, risk strategy, compliance with regulatory aspects and the level of doing so whether applying the bare accepted minimum or by stipulating the best practices that usually go beyond basic regulatory requirements (Barth and Caprio, et al., 2002). 
To outline the principles of banking management and thus risk taking that should be taken into account by the shareholders and the Regulator, the national legislation (mostly the Law on Commerce or similar legislation in other countries) are relevant as it differentiates between Two-Tier or One-Tier or other governance structures (liabilities, constraints of specific members of the management body, including structure) (The Law on Commerce, various Articles).

In Latvia, there is a Two-Tier structure, which means that management body is divided into two separate functions - supervisory function and management function (The Regulation on the Establishment of the Internal Control Framework, 2012). The supervisory board represents the shareholders' interests, supervises the management board and does not undertake the executive functions (the Law on Commerce Article 293).

There are clear rules that separate these two boards as it is internationally accepted standards that the same people should not engage into business decisions and at the same time supervise these decisions (European Banking Authority (EBA) guidelines on corporate governance, 2017). Nevertheless, this may occur in certain cases as small, open economies with certain national economic values hold banks that demonstrate power concentration with certain people that are promoted in significant directorships and decision-making process is mostly too concentrated to often be objective (The FCMC, 2017; Information about shareholders and members of the management body from Latvian commercial banks). The business decisions therefore might not fully be aligned with minority shareholders, and maybe are not in the best interests of investors and account for high-risk business. On the contrary, power concentration more effectively rules out agency problems that stem from members of the management body, which is also ruinous because materialistic incentives from members of the management body result in higher risks and ineffective risk management function in banks (Bushman and Davidson, et al., 2018).

With underrepresented minority shareholders that would have any rights at the important decisions and insufficient corporate governance standards the information flows that would enhance prudent management of the bank are therefore non-existent. If the bank has the necessary policies and procedures that are required by the Regulation of the Establishment of Internal Control Framework (2012) then for the Regulator to check actual efficiency of these requirements is difficult or even impossible. If the senior management and the members of the management body do not act independently (they are unfit and improper for the directorship in practice) as they are supposed to be, and with no viable options to report non-compliance (reporting lines, whistle blowing) at the highest level of management - would relate to major issues with unsuitable staff that works only at the interests of majority shareholders.

It is notable that the banks of Lat via, whether they are Joint Stock Corporations (JSC), are not listed stock corporations and the liability of those banks are strictly limited to the regulation and criminal penalties that also foster irresponsible 
decisions of the shareholders. The stocks are owned by a small number of people that directs all the business by themselves, which carries numerous amounts of risk (majority shareholder problem discussed previously). It may be historical specificity that has kept these JSC unlisted and strictly owned by certain people.

Staff suitability is also the issue in the case if the only shareholder (or majority shareholder as well) is a parent institution - factor may drive subsidiary to rely too much on parent institutions' group wide decisions and that is against the prudent management of the institution as a separate entity (EBA guidelines on corporate governance, 2017).

Excessive reliance on the parent institution has other downsides, for example, the risk that the bank will form a "shell bank" that is particularly gaining extra attention regarding Brexit plans and ECB response to strengthen Euro Area by stepping up with zero tolerance towards "shell bank" entities that do not have sufficient internal governance at the individual level (ECB, 2017). Stepping up to parent institution decisions that may not always be in the best interest of the subsidiary, is one of the most challenging risk-taking initiative of subsidiaries' staff that can lead to detrimental effects on the stability of subsidiary itself. Therefore, it is expected that group impact is very significant in every business decision.

A bank is deemed to undertake risks even with regulations present. It is expensive for the bank to establish adequate internal control system within its functions - risk management, compliance and audit functions, therefore the bank 'de facto' will always try to reduce these compliance related costs (Noonan, 2015) that reduce the profit.

In addition, one of the largest risk-taking incentives for adding shareholders value is the dividend pay-out policy that always is the decisive driver for not using profit as capital strengthening tool, but as faster option to obtain dividends. These incentives also apply to the members of the management body and certain staff of senior managers that are classified as risk takers for the purposes of remuneration policy and pay-out rules (Regulation (EU) No 604/2014, 2014). This risk-taking incentive regarding remuneration is stronger in banks with the problem of power concentration of significant directorships as the management body and shareholders have too close personal incentives to approve inadequate compensation schemes and additional variable remuneration (bonus cap).

This allows one to conclude that the hypothesis that the stronger framework of corporate governance is established the more incentives of risk taking of the bank are mitigated. The authors assessed publicly available information from the FCMC on the amount of penalties that banks acquired given their faults on the internal control systems and the amount of fine that had to be paid and other agreements that had to be undertaken (see Annex 1, Table 1). Therefore, it is possible to confirm that the non-resident servicing banks that are generally more profitable are lacking the most requirements of the internal control system (Bojāre and Romānova, 2017). 


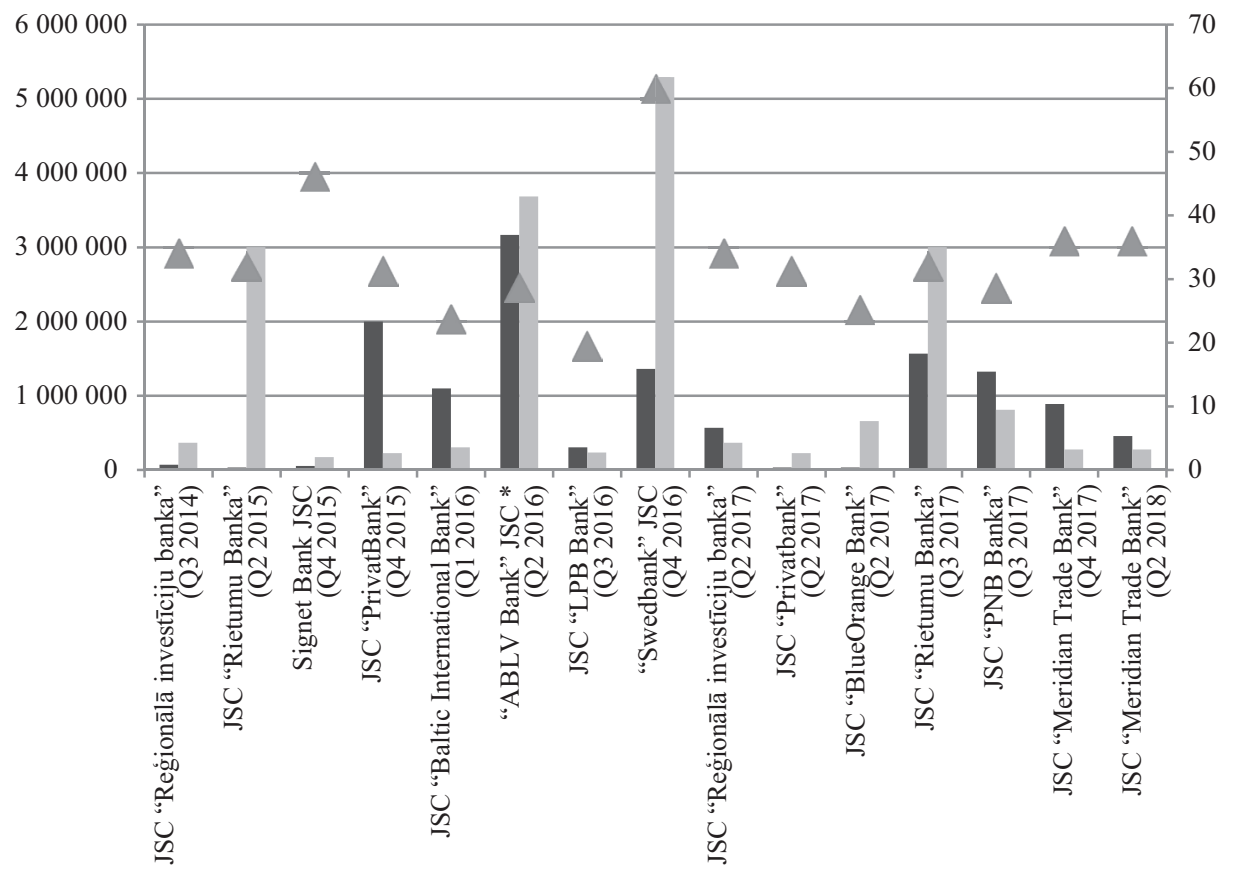

- Penalty amount, euro $\quad \square$ Total assets as of $2017 \mathrm{Q} 4,1 * 10^{\wedge} 3$ euro $\quad \Delta$ Loan to assets ratio, $\%$

Source: the FCMC

Fig. 4. Monetary penalty statistics of Latvian banks by punishment date, total assets and loan to assets ratio

As an example, the regulatory aspect just recently increased for Latvian banks as the Chairman of the FCMC declared (LETA, 2018) that non-resident servicing business is not an option for Latvian banking market anymore and should be winded down significantly. The extensive penalties (Annex 1, Table 1) confirms this fact. As Figure 4 shows, all banks that have received penalties regarding insufficient internal control systems and excessive risk taking are all oriented to non-residential clients (except one case of "Swedbank" JSC). By using the non-residential business type identification approach - the loan to asset ratio the authors conclude that the correlation between receiving penalty and risky business model is evident. Similar approach was used by Jakobsons and Schaub (2014) in the means of identification of business models who divided Latvian' banking sector with the indicator loans to deposit ratio. As this indicator has the same correlation and trend as loan to assets ratio, overall it can be assumed as valuable business model identifier for research purposes.

Given recent scandals with banking business model choices that are unsustainable, the aspect of competitiveness in Latvia grows larger as banks with non-resident servicing business models struggle to find new market options, 
new business ways and new approaches in relatively small banking market (The Economist, 2018). This at the same time may lead to a new wave of excessive risk taking for some of those banks that fight for survival given recent regulatory activities. These decisions, however, will damage the shareholders' value and may threaten the investors and thus require additional supervisory approaches given historic cases.

\section{SySTEMIC INCENTIVES}

While the previous section of the article described the institution specific incentives for excessive bank risk taking this section focuses on systemic incentives.

Analysing systemic incentives is a complex task due to existing linkages between actors and the prevalent market rules. As mentioned in the first section one of the main drivers for excessive bank risk taking are incomplete markets and contracts (Allen and Gale, 2006) that lead to banks using legislative loopholes.

An incentive that is important in the economy that is not only open and small, but also has relatively no power to set exchange rate, is appreciation of real effective exchange rate that leads to deteriorating trade competitiveness. This factor worsens the ability of enterprises to repay loans and other liabilities to banks and as a result bank asset value drops and possible liquidity and soundness risk arises. Therefore, banks are interested in maintaining a stable real effective exchange rate or limit their exposure towards enterprises in a particular market.

A market-defined incentive for banks to take excessive risk is the limited size of a market banks work in. The banking system in such particular small market is highly competitive (Beck, De Jonghe and Schepens, 2013) and to have high enough yields banks are encouraged to take upon excessive risks (Petrovska, 2017). In addition, the Regulator might push for increased capital buffers. For instance, if the Regulator sets a level of mandatory capital buffers too high (Allen and Gale, 2006) - banks are forced to increase the profitability of other assets that are not frozen - therefore increase their riskiness in the process.

A major drawback towards independence in the supervision of the banks is the aspect of the Regulator to act in line with the maximization of society's utility aspect over the competition with other regional Regulators that might arise given every country's individual interests. A Regulator in a small, open economy cannot create regulation in isolation from the rest of the region or even whole world because if rules are too strict the investors will choose to settle elsewhere. If the local Regulator is dependent on rules set by higher authority in a region (like Euro Area with European Central Bank foreseeing the whole region) the needs of the local Regulator can be diminished towards the needs for regulation of the largest member states.

The next systemic incentive for excessive risk taking by banks is the Regulator's preference for exact asset types like AAA bonds (Black et al., 2016) 
that lead to scarceness of the exact asset types and increased demand for these assets that further lead to increased price. Besides not only Regulator's preference, but also peer bank preference for exact asset types from the same regions lead to correlated assets and excessive risk taking. This is especially pivotal in small, open economies with preferences relating to regional specificities. For instance, banks in Latvia prefer bonds issued by governments in Euro Area, US and Commonwealth of Independent States (CIS) (FCMC, 2018).

A recently observed phenomenon is banks engaging in financial innovation and close cooperation with FinTech and other technology enterprises. Moreover, while these innovations are not adequately regulated (Guerra et al., 2013) a potential for excessive risk taking emerges as shareholder appetite for profits rises.

Another systemic incentive for excessive risk taking is the perception by banks that the Regulator will favour domestic or systemically important institutions (Garratt, Webber and Willison, 2012; Espinosa-Vega et al., 2011) over other type of banks and therefore biased bailouts would occur. This leads to changes in behaviour to increase the bank's importance within the economy.

Due to tax shields, enterprises have a preference towards choosing corporate debt rather than equity when investing (de Mooij and Hebous, 2017). This leads to favouritism towards banks and in turn, banks choose to lend to enterprises in form of loans rather than option for other types of financial instruments to hold as their assets. Within the limited size of the domestic market, more risky loans are issued than in a market where banks are able to easily decline holding risky credit.

Excessive risk undertaking is further stimulated by behaviour of depositors. For instance, depositors in general are more lenient towards choosing banks to deposit funds if deposit insurance is in force (Laeven, Ratnovski and Tong, 2016). In addition, depositors are more careless for bank behaviour and their risk appetite when their domestic country is wealthy - high GDP per capita (Laeven, Ratnovski and Tong, 2016). When depositors do not sufficiently supervise banks with their deposits and withdrawals, banks tend to be more careless towards depositors and undertake riskier assets.

Another pressure for banks to take excessive risks is the prevalence of fixed rate deposits (Allen and Gale, 2006). That means that banks are forced to invest in projects that yield at least the rate promised for the deposits. However, the return of any investment project is not certain therefore banks have to take riskier projects to offset potential losses and repay depositors.

The herding behaviour by banks (Acharya and Yorulmazer, 2003) also promotes excessive risk taking especially when operating within a limited market. This behaviour leads to higher profits during the boom of the economy, but also shared higher losses during the bust. The limited size of market also plays a role as banks have to compete for the most profitable investment opportunities, sometimes at the expense of their soundness. 
The final systemic incentive for excessive risk taking by banks is the prevalence of syndicated loans in the economy (Allen, Babus and Carletti, 2010). Syndicated loans tend to increase the overlap of the investment portfolios. Besides in a small economy usually few large enterprises are present therefore, banks compete with each other to finance these large enterprises and this increased competitiveness could lead to risks not evaluated.

\section{Resulting OUTCOMES}

After the previous two sections with the exploration of the incentives for excessive risk taking by banks, this section conceptualizes the theoretical and empirical resulting outcomes of such behaviour.

The summarisation of bank specific aspects that are key risk-taking factors would be the cost reduction at the expense of compliance (Noonan, 2015). It can be assumed that banks engage in risky businesses to obtain more profit. In the case of small and open economy such as Latvia, the banks that focus on non-residential clients are those that are more profitable (Bojāre and Romānova, 2017). Moreover, the Regulator approaches these banks with higher regulatory requirements mostly in the area of capital buffers, liquidity and internal governance, but more notably in the field of anti-money laundering and terrorism financing risk management (the FCMC, 2017). Large monetary and other types of penalties prove that risky banking business models are ruinous for the economy, investors and other stakeholders and interested parties.

In the case of a level playing field with these banks - the same regulatory framework both for banks that service mostly residential clients and banks that serve mostly non-residential clients - the one and only resulting outcome for an individual bank would be its solvency issues as it would eventually engage in too risky business decisions and suffered ineffective risk management for the bank to maintain sound capital and liquidity levels (Hugonnier and Morellec, 2017). This will eventually damage the shareholders wealth. There would not be any backstop for minority shareholders as those would not be in the shareholder structure in the case of non-existent or weak minority shareholder protection. The dominance of majority shareholders would cast out groupthink and effective promotion of members of the management body would also be non-existent. The same problems apply with parent institution excessive dominance.

As for other outcomes that may result from excessive risk taking - financial difficulties such as the inability to repay deposits and other claims might arise, but in this case, the insolvency aspect will play its role. Every negative outcome and/ or situation that relates to bankers' decisions sheds a dark light upon reputation and trust that is vital in banking business. The business has to be restructured or closed down if the risks are too large to manage and the Regulator would choose not intervene. 
Any negative resulting outcome of the excessive bank risk taking will lead to losses of the investors and other interested parties not only in micro level, but will also have an impact in the macro level.

During times of turmoil, panic and runs on banking system occur even in the absence of direct linkage between bank in distress and other peers (Lau, 2011). Besides, in a small, open economy runs happen not only by individuals residing in the country, but also from global investors and these runs are more abrupt than would be in large economy. Inability to correctly evaluate assets leads to depressed asset value and possible bank insolvency (Diamond and Rajan, 2011).

A country's ability to fulfil obligations also play a role in triggering the bank runs especially when small, open economies have lower resistance towards mitigating shocks.

Excessive risk taking force banks to get creative in maintaining their profitability. Recent studies show that not only depositors, but also banks themselves try to expand in the usually non-regulated shadow banking business (Financial Stability Board, 2015) for maintaining their comparative advantage.

Due to the interconnectedness of a small, open economy, distress in one country easily spreads to the whole region. The consequences of excessive risk taking in a single market leads to the disruption of market functioning and distress in the whole region (Huang, Zhou and Zhu, 2012). Once the shock event emerges the freeze of credit sales starts. In addition, liquidity shortages and interbank linkages get broken (Laeven, Ratnovski and Tong, 2016).

Another outcome is the occurrence of the inefficient government bailouts when banks are in distress (Laeven, Ratnovski and Tong, 2016) from previous incorrectly evaluated risk. These funds usually come from taxpayer money that cannot be further invested in improving health, education, transportation or other needs of the society.

When the banking sector loses the confidence of investors due to previous excessive risk-taking defaults, fire sales and counterparty fear emerges (Garratt, Mahadeva and Svirydzenka, 2011). This leads to consolidation of the banking sector as only the strongest are able to raise funds and confidence.

Another outcome of excessive risk taking is a decrease in rating (Sy, 2009) for not only the bank in question, but also for all banks operating in the same market. The decrease in rating leads to an increase of the cost of borrowing.

The overall cost of borrowing increases (Acharya and Yorulmazer, 2003) as lenders are more suspicious towards the whole sector even if excessive risk taking was evident only in few banks.

Overall, it can be concluded that there are various negative outcomes from excessive risk-taking incentives. 


\section{Discussion OF RESULTS}

As it is seen from the previous sections, the banking sector as a whole plays an important role in not only providing funds for development of the economy, but also collects and distributes various risks. Besides, nowadays banks also take part in creation of a nation's wealth and invests in innovative economy by joint ventures with technological enterprises.

Another point worth discussing is that recently bank specific incentives to take upon activities with questionable reputation by having improper antimoney-laundering standards have been penalised by Regulator, at least in Latvia (Annex 1, Table 1). These incentives are often difficult to manage as they result from bank specificities regarding ownership status, structure and overall attitude towards business decisions.

The systemic incentives are seen to be arisen from an incomplete and small market itself. Therefore, the role of a fair Regulator and a legislative framework is crucial both from micro and macro level perspective.

Some incentives have more ruinous consequences than others. The results of this study show that mostly all incentives have progressed over time. That leads to the thought that also the Regulator has to adapt faster towards mitigating and controlling the incentives. The authors have also found that the factor of a small, open economy plays a determinative role in monitoring incentives. Not only banks have to implement strategies based on regional market specificities, but also the Regulator has to adapt as well. A single Regulator cannot set stricter rules than the neighbouring countries' Regulators for their particular markets as then, due to the free movement of capital (or at least easily), the banks will choose to re-settle over in neighbouring markets since the regulatory level playing field cannot be met in practice. The regional competitiveness over funds, clients and even amiability of the Regulator have started to play a definite role. This all leads to the limited Regulator's power to act independently and in a timely manner.

\section{CONCLUSIONS}

1. To steer bankers from pure profit making to prudent business management the corporate governance framework has to be strengthened by various factors in which, among others, sound risk culture and effective internal control system that facilitates long-term interests of investors plays an important role. There are various requirements that have to be met for a bank given its nature and importance in any economy. Especially in a small, open economy like Latvia.

2. In small, open economies with certain national and cultural aspects, there are problems with correct shareholder representation through management body members. The dominance of majority shareholders is present. This enables problems regarding the prudent decisions on behalf of the bank and abstraction from own personal business decisions more effectively. 
3. Not mitigating incentives (bank specific or systemic) will lead to systemic events with catastrophic effects. However, if these incentives will not be controlled (and worst - penalised) by an outside party (be it the Regulator, global market participants or even depositors) the probability of risk realisation increases.

4. Some of the incentives have more ruinous consequences than others do. Therefore, the mitigation process should be firstly directed towards those with most disastrous consequences.

5. Due to regional competitiveness in mitigation (or leniency towards mitigation) of incentives takes place constantly, the implementation of Regulatory strategy has to be independently evaluated and fairly adjusted over time.

6. Incentives have progressed over time and are business cycle and regulatory framework dependant.

7. Overall, the hypotheses set out in this study were confirmed. Particularly that strong internal governance framework enables more prudent and sound risktaking behaviour in a bank, that leads toward minimising negative resulting outcomes. Systemic incentives are more difficult to minimise as they arise from various agents and market structure as such, but have a potential of disrupting the entire banking system.

\section{PROPOSALS \& RECOMMENDATIONS}

1. To the Regulator - stricter oversight of financial innovations and shadow banking sector. Simultaneously evaluate the necessary intervention. In addition, to have strict supervisory approach regarding bank specific risk taking that is often a starting point for every ruinous decision and outcome. Carry out supervisory review and evaluation process for every bank regardless of its size and systemic importance;

2. To fiscal and monetary policy makers to introduce a financial transaction tax for transactions that promote systemic risk in order to create "systemic event" fund;

3. Banks must look for opportunities to diversify their investment portfolios (both in terms of sector of national economy and in terms of services provided) in order to avoid excessive asset correlation and dependency between assets of mutual investment portfolios;

4. Banks must introduce in practise the best practices in their institution regarding internal governance related aspects, prudent capital and liquidity management, careful consideration of business model and its decisions. The shareholder structure should always be considered as groupthink phenomenon should not be dominant; 
5. To the Regulator and banking system agents - implementation of continuous monitoring of current and newly developing incentives;

6. To other researchers - the institution specific view in bank related research should be analysed closely with systemic perspective view (micro and macro levels).

\section{REFERENCES}

Acharya, V. V. and Yorulmazer, T. (2003), Information Contagion and Inter-Bank Correlation in a Theory of Systemic Risk. SSRN Electronic Journal, 44(0). doi: $10.2139 /$ ssrn.365940.

Allen, F., Babus, A. and Carletti, E. (2010), Financial connections and systemic risk. European University Institute Working papers, (ECO 2010/26), p. 37. doi: ISSN 1725-6704.

Allen, F. and Gale, D. (2006), Systemic Risk and Regulation. Wharton Financial Institutions Center Working Paper, pp. 1-35. Available at: http://fic.wharton.upenn. edu/fic/papers/05/0524.pdf\%5Cnpapers2://publication/uuid/CB51372C1C43-4DE8-98BD-2272041B43FA.

Bank for International Settlements, 2015. Basel Committee on Banking Supervision, Guidelines on Corporate governance principles for banks. Basel: Bank for International Settlements.

Barth, R. J., Caprio, Jr. G., Levine, R., 2002. Bank Regulation and Supervision: What Works Best? - Workshop "Basel II - An Economic Assessment". Available at: https:// www.bis.org/bcbs/events/b2ealev.pdf

Beck, T., De Jonghe, O. and Schepens, G. (2013), Bank competition and stability: Crosscountry heterogeneity. Journal of Financial Intermediation, 22(2), pp. 218-244. doi: 10.1016/j.jfi.2012.07.001.

Black, L. et al. (2016), The systemic risk of European banks during the financial and sovereign debt crises. Journal of Banking and Finance, 63, pp. 107-125. doi: 10.1016/j.jbankfin.2015.09.007.

Bloomberg. ECB Blasts Banks for 'Empty Shell' Brexit Plans, Risk Transfers. Retrieved from: https://www.bloomberg.com/news/articles/2017-11-15/ecb-blastsbanks-for-empty-shell-brexit-plans-risk-transfers

BNN 2016. KPMG: Baltics become more active in FinTech sector. [Online]. Available at: http://bnn-news.com/kpmg-baltics-become-more-active-in-fintech-sector155195

Bojāre, K., Romānova, I., 2017., The Factors Affecting the Profitability of Banks: The Case of Latvia. European Research Studies Journal, Volume XX, Issue 3A, pp. 905-919.

Bushman, M. R., Davidson, H. R., Dey, A., Smith, A., 2018. Bank CEO materialism: Risk controls, culture and tail risk. Journal of Accounting and Economics 65, pp. 191-220. doi: 10.1016/j.jacceco.2017.11.014

Central Statistical Bureau of Latvia. JVSG01: Occupied posts by kind of economic activity on average per year. [Online]. Available at: http://data.csb.gov.lv/pxweb/en/ Sociala/Sociala_ikgad_aiznemtdv/jvs0010g.px/?rxid=cd

Commission Delegated Regulation (EU) No 604/2014 supplementing Directive 2013/36/EU of the European Parliament and of the Council with regard to 
regulatory technical standards with respect to qualitative and appropriate quantitative criteria to identify categories of staff whose professional activities have a material impact on an institution's risk profile, 2014. Official Journal of the European Union. Brussels: European Parliament and the Council.

Diamond, D. W. and Rajan, R. G. (2011), Fear of fire sales, illiquidity seeking, and credit freezes. Quarterly Journal of Economics, 126(2), pp. 557-591. doi: 10.1093/ qje/qjr012.

Directive 2013/36/EU of the European Parliament and of the Council of 26 June 2013 on access to the activity of credit institutions and the prudential supervision of credit institutions and investment firms, amending Directive 2002/87/EC and repealing Directives 2006/48/EC and 2006/49/EC, 2013. Official Journal of the European Union. Brussels: European Parliament and the Council.

ECB. Various sources. [Online]. Available at: https://www.bankingsupervision.europa. $\mathrm{eu} / \mathrm{home} / \mathrm{html} /$ index.en.html

Espinosa-Vega, M. et al. (2011), Systemic Risk and Optimal Regulatory Architecture. International Monetary Fund-Working Paper, (11/193).

European Banking Authority, 2017. Guidelines on internal governance (EBA/ GL/2017/11). London: European Banking Authority.

European Central Bank, 2017. What is SREP. Available at: https://www.bankingsupervision.europa.eu/about/ssmexplained/html/srep.en.html

Eurostat. Annual Accounts by Institutional Sector. [Online]. Available at: http:// ec.europa.eu/eurostat/documents/499359/6277543/LV_BLUE_NAC_WEB. xlsx

Eurostat. Contributions of each institutional sector to macroeconomic developments. [Online]. Available at: http://ec.europa.eu/eurostat/web/sector-accounts/ detailed-charts/contributions-sectors

European Central Bank. Debt excluding trade credit of Non financial corporations as a ratio of GDP. [Online]. Available at: http://sdw.ecb.europa.eu/quickview.do;jsessionid $=285217284$ E609BE8BBD2FEAAC6282065 ?SERIES_KEY=332.QSA.Q.N.LV. W0.S11.S1.P.L.LE.FP.T._Z.XDC_R_B1GQ_CY._T.S.V.N._T

Financial Stability Board (2015), Transforming Shadow Banking into Resilient Marketbased Financing. (November), pp. 1-14. Available at: http://www.fsb.org/wpcontent/uploads/shadow_banking_overview_of_progress_2015.pdf.

Garratt, R. J., Mahadeva, L. and Svirydzenka, K. (2011), Mapping systemic risk in the international banking network banking network. Bank of England Working Paper, (No. 413), pp. 1-41. doi: 10.2139/ssrn.1786571.

Garratt, R. J., Webber, L. and Willison, M. (2012), Using Shapley's asymmetric power index to measure banks' contributions to systemic risk. Bank of England Working Paper No. 468, pp. 1-22. Available at: https://papers.ssrn.com/sol3/papers. cfm?abstract id $=2167335$

Guerra, S. M. et al. (2013), Systemic Risk Measures. Working Paper Series. Banco Central do Brasil, (321), pp. 1-20.

Huang, X., Zhou, H. and Zhu, H. (2012), Assessing the systemic risk of a heterogeneous portfolio of banks during the recent financial crisis. Journal of Financial Stability, 8(3), pp. 193-205. doi: 10.1016/j.jfs.2011.10.004.

Hugonnier, J., Morellec, E., 2017, Bank capital, liquid reserves, and insolvency risk. Journal of FinancialEconomics 125, pp. 266-285. doi: 10.1016/j.jineco.2017.05.006

Information about shareholders and members of the management body from Latvian commercial banks. 
Jakobsons, A., Schaub, W. C., 2014. Study on the Present Competitive Performance and Future Prospects of the Banking Industry in Latvia. Riga: Riga Business School (Riga Technical University).

KPMG 2017. FinTech 100. Leading Global FinTech Innovators. [Online]. Available at: https://s3-ap-southeast-2.amazonaws.com/h2vc/static/reports/innovators/ 2017/H2-Fintech-Innovators-2017.pdf

Laeven, L., Ratnovski, L. and Tong, H. (2016), Bank size, capital, and systemic risk: Some international evidence. Journal of Banking and Finance. Elsevier B. V., 69, pp. S25-S34. doi: 10.1016/j.jbankfin.2015.06.022.

Lau, J. (2011), Fat Tails and Their (Un) happy Endings: Correlation Bias and Its Implications for Systemic Risk and Prudential Regulation (EPub). IMF Working Paper, 11(WP/11/82), pp. 1-22.

LETA, 2018. FKTK vadītājs: Latvijas bankās pieḷujamais ārvalstu klientu biznesa apmèrs ir ap 5\% (ENG: Chairman of the FCMC: tolerated level of non-residential clients in Latvian banks is around 5\%). [Online]. Available at: https://www.lsm.lv/raksts/ zinas/ekonomika/fktk-vaditajs-latvijas-bankas-pielaujamais-arvalstu-klientubiznesa-apmers-ir-ap-5.a271529/

Mooij, R. A. de and Hebous, S. (2017), Curbing Corporate Debt Bias: Do Limitations to Interest Deductibility Work? IMF Working Paper Fiscal Affairs Department, (WP/17/22), pp. 1-20.

Petrovska, K. (2017), Causes and Consequences of Systemic Risk in Relation to Latvia. in New Challenges of Economic and Business Development - 2017: Digital Economy. Riga: University of Latvia, pp. 387-396. Available at: https://www.bvef.lu.lv/ fileadmin/user_upload/lu_portal/projekti/evf_conf2017/Proceedings_of_ Reports.pdf.

Regulation (EU) No 575/2013 of the European Parliament and of the Council of 26 June 2013 on prudential requirements for credit institutions and investment firms and amending Regulation (EU) No 648/2012, 2013. Official Journal of the European Union. Brussels: European Parliament and the Council.

Sy, A. N. R. (2009), The systemic regulation of credit rating agencies and rated markets. IMF Working Paper, (WP/09/129), pp. 1-37. doi: 10.2139/ssrn.1422699.

The Economist, 2018. Latvia's top banking official is accused of demanding bribes. [Online]. Available at: https://www.economist.com/news/business-and-finance/ 21737224-claims-moneylaundering-and-corruption-stain-latvias-bankingsystem-latvias-top

The FCMC. Various sources. [Online]. Available at: http://www.fktk.lv/en/

The Financial and Capital Markets Commission Regulation No 233, Regulation on Establishment on internal control system Framework, 2012. [Online]. Available at: https://likumi.lv/doc.php?id=252578

The Saeima of Latvian Republic. The Law on Commerce, 2002. [Online]. Available at: https://likumi.lv/doc.php?id=5490

United States Department of Justice, 2015. Herfindahl-Hirschman Index. [Online]. Available at: https://www.justice.gov/atr/herfindahl-hirschman-index 


\section{AnNex I}

Table 1. Monetary and other penalties of Latvian banks since 2014

\begin{tabular}{|c|c|c|c|}
\hline BANK & $\begin{array}{c}\text { DATE OF } \\
\text { PUNISHMENT }\end{array}$ & $\begin{array}{l}\text { PENALTY } \\
\text { (EUR) }\end{array}$ & REASONING \\
\hline $\begin{array}{l}\text { JSC "Meridian Trade } \\
\text { Bank" }\end{array}$ & 25.05.2018. & 455822 & $\begin{array}{l}\text { Overall insufficient internal control system. Mostly in } \\
\text { the AML risk management area }\end{array}$ \\
\hline $\begin{array}{l}\text { JSC "Meridian Trade } \\
\text { Bank" }\end{array}$ & 14.11 .2017$. & 889651 & $\begin{array}{l}\text { Insufficient internal control system in the credit risk } \\
\text { area }\end{array}$ \\
\hline $\begin{array}{l}\text { JSC "NORVIK } \\
\text { BANKA"(currently } \\
\text { JSC "PNB Banka") } \\
\text { JSC "Rietumu Banka” }\end{array}$ & 21.07.2017. & 1566604 & $\begin{array}{l}\text { The FCMC in cooperation with USA FBI investigated } \\
\text { that both banks have not complied with regulation } \\
\text { in the field of AML and internal control systems. } \\
\text { Investigation concluded that the internal control } \\
\text { system was not efficient given banks' business model. }\end{array}$ \\
\hline $\begin{array}{l}\text { JSC "Baltikums Bank" } \\
\text { JSC "Privatbank" } \\
\text { JSC "Reǵionālā } \\
\text { investīciju banka" }\end{array}$ & 27.06.2017. & $\begin{array}{r}35575 \\
35575 \\
570364\end{array}$ & $\begin{array}{l}\text { JSC "Baltikums Bank" and JSC "Privatbank" lacked } \\
\text { certain provisions in the field of AML that was } \\
\text { discovered as part of international investigation. JSC } \\
\text { "Regionālā investiciju banka" lacked compliance } \\
\text { with crucial internal governance aspects additional } \\
\text { to provisions in the field of AML therefore the } \\
\text { penalty additional to monetary fine consisted } \\
\text { with requirement to invest } 2.8 \text { million euro in } \\
\text { strengthening internal control system framework in } \\
\text { fore coming year. }\end{array}$ \\
\hline JSC "Swedbank" & 23.11.2016. & 1361954 & $\begin{array}{l}\text { Bank settled an agreement for monetary fine and } \\
\text { additional activities to strengthen the internal control } \\
\text { framework that had some major issues regarding AML } \\
\text { and other aspects (know your client). }\end{array}$ \\
\hline $\begin{array}{l}\text { JSC “Latvijas pasta } \\
\text { banka” }\end{array}$ & 25.07 .2016 & 305000 & $\begin{array}{l}\text { The investigation regarding the publicly available } \\
\text { research of National Bank of Moldova (Kroll report) } \\
\text { about activities in the banks of Moldova in } 2012 \\
\text { and } 2013 \text { that concluded into penalty for the Bank } \\
\text { regarding aspects in the field of AML and inefficient } \\
\text { internal control framework. }\end{array}$ \\
\hline JSC "ABLV Bank"1 & 26.05.2016. & 3166682 & $\begin{array}{l}\text { The FCMC settled an agreement with the Bank } \\
\text { and Head of AML Officer (Aleksandrs Pàže) for a } \\
\text { monetary fine additional to further enhancement } \\
\text { of internal control system that had serious errors } \\
\text { regarding aspects of AML. This settlement requested } \\
\text { the Bank to invest additional } 6.5 \text { million euro to } \\
\text { strengthen its internal control system. }\end{array}$ \\
\hline $\begin{array}{l}\text { JSC "Baltic } \\
\text { International Bank" }\end{array}$ & 09.03.2016. & $\begin{array}{c}1100000 \\
\text { (The bank), } \\
25000 \text { (CEO) }\end{array}$ & $\begin{array}{l}\text { The bank lacked crucial details regarding the AML risk } \\
\text { management and endangered the bank to excessive } \\
\text { risks. The bank agreed to strengthen its internal } \\
\text { control system in the field of AML risk management. }\end{array}$ \\
\hline $\begin{array}{l}\text { JSC “TRASTA } \\
\text { KOMERCBANKA" }\end{array}$ & 03.03.2016. & $\begin{array}{c}\text { License } \\
\text { suspended }\end{array}$ & $\begin{array}{l}\text { The bank was previously fined regarding similar } \\
\text { problems therefore the license suspension that was } \\
\text { made by the FCMC and ECB was an outcome. Banks' } \\
\text { shareholders were not able to raise capital and comply } \\
\text { with regulatory requirements for some time. The bank } \\
\text { was already working with significant losses and the } \\
\text { chosen business model was not sustainable. }\end{array}$ \\
\hline
\end{tabular}

1 12.06.2018. The FCMC permits JSC "ABLV Bank" to implement voluntary liquidation due to unrepairable fallout of negative reputation risk after public suspicions' of faults in the AML area. 


\begin{tabular}{|c|c|c|c|}
\hline BANK & $\begin{array}{c}\text { DATE OF } \\
\text { PUNISHMENT }\end{array}$ & $\begin{array}{l}\text { PENALTY } \\
\text { (EUR) }\end{array}$ & REASONING \\
\hline JSC "PrivatBank" & $\begin{array}{l}11.12 .2015 / \\
14.12 .2015 .\end{array}$ & $\begin{array}{c}2000000 \\
\text { (Bank), } \\
\text { individual } \\
\text { penalties for } \\
\text { management } \\
\text { board } \\
\text { members - } \\
96449 \text { (CEO); } \\
\text { others - } \\
25869,15411 \\
\text { and } 7607 \\
\end{array}$ & $\begin{array}{l}\text { Critical faults in the field of AML risk management led } \\
\text { to the suspension of the management board additional } \\
\text { to monetary fine for each of them and the bank itself. } \\
\text { The investigation regarding the publicly available } \\
\text { research of National Bank of Moldova (Kroll report) } \\
\text { about activities in the banks of Moldova in 2012-2014 } \\
\text { was also taken into account. Further work regarding } \\
\text { the enhancement of the internal control system and } \\
\text { also the management of AML risks are taking place. }\end{array}$ \\
\hline $\begin{array}{l}\text { JSC "Bank M2M } \\
\text { Europe” (currently } \\
\text { JSC “Signet Bank") }\end{array}$ & 27.11 .2015 . & 55000 & $\begin{array}{l}\text { Faults in the management of AML risks and } \\
\text { shortcomings in the internal control system led to } \\
\text { penalty. }\end{array}$ \\
\hline JSC "Rietumu Banka” & 15.05 .2015 & 35000 & $\begin{array}{l}\text { Shortcoming in the field of AML risk management } \\
\text { (know your client) and insufficient internal control } \\
\text { system led to penalty. }\end{array}$ \\
\hline $\begin{array}{l}\text { JSC "Regionālā } \\
\text { investīciju banka" }\end{array}$ & 04.07.2014. & 70000 & $\begin{array}{l}\text { Insufficient non-residential client investigation but } \\
\text { the bank led to serious faults that were crucial for the } \\
\text { penalty. The requirement to strengthen the internal } \\
\text { control system was made for the bank in upcoming } \\
\text { years. }\end{array}$ \\
\hline
\end{tabular}

Source: the FCMC 


\title{
OPPORTUNITIES FOR ASSESSMENT OF HEALTH CARE SYSTEM'S EFFICIENCY: THREE-LEVELS EVALUATION MODEL
}

\author{
DIĀNA ARĀJA \\ JĀNIS PRIEDE
}

\begin{abstract}
The efficiency of health care systems becomes crucial in circumstances of the rising costs of health technologies and strictly limited resources allocated from the public budget. Within the framework of this research, the authors evaluate the opportunities to assess the efficiency of health care systems. To achieve the goal of the research, the methods of the theoretical research (literature analysis, content analysis, and electronic resources analysis) are used alongside the methods of the empirical research (data collection methods: document analysis and database statistical analysis). For data processing and analysis, methods of economic analysis and statistical analysis are used. To perform this research the authors have created a three-level performance evaluation model based on macro-level evaluation (policy impact assessment), meso-level evaluation (system analysis, functional and economic efficiency measuring) and micro-level evaluation (production function, allocative and technical efficiency measures, market analysis). The measures of the macro impact results, policy outcomes and performance outputs are tested to evaluate the efficiency of health care system. The ex-post pilot-evaluation of the Latvian health care reform leads to conclusion of its temperate low functional effectiveness, but substantial productive efficiency in scores of the reorganisation of institutional framework. The general conclusion concerning to the health care services and reimbursement system of medicines and medical devices shows the tendency to move towards technical efficiency, rather than total economic efficiency (technical and allocative efficiency), as the treatment alternatives (nutrition programs, physician's time by consultation, complementary therapy etc.) are not sufficiently taken into account. The suggested methodology for efficiency assessment of health care system has substantial theoretical and practical implication for decision-making process on health care organisation and financing.
\end{abstract}

Key words: Latvia, health care system, organisational theories, risk management, efficiency, assessment

JEL code: H51, I11, I18

\section{INTRODUCTION}

Promoting good health is an integral part of Europe 2020, the European Union's 10-year economic-growth strategy (European Commission, 2010). The 
Declaration on the Intended Activities of the Cabinet of Ministers of Latvia has defined that the health care system in Latvia receives significantly less funding from the state budget than those of other European Union countries. Therefore, the proportion of patient co-payments for health care services is one of the highest in Europe. This has a substantial negative impact on access to health care and is a factor contributing to inequalities in health. The health care financing system needs to be reformed in order to preserve and improve people's health, which is the basis for long and productive working lives, as well as to increase the birth rate and promote employment in the country, thus ensuring sustainable economic development. Development of a sustainable health care funding system to improve access to services at all levels of health care has been defined as a one of the priorities of the Government of Latvia (Cabinet of Ministers, 2016).

In spite of the government-defined priorities, the European Commission, at Country Report Latvia 2018, has identified the challenged tendencies. According to the above-mentioned report, Latvia has implemented a major tax reform and is pursuing reforms in other key areas like healthcare, education and public administration, but their effectiveness varies, particularly (European Commission, 2018):

- public administration reforms have advanced little over the previous years, with several proposals presented, but few adopted. Ideas for increasing efficiency of public administration were tabled in 2016 and the Government in 2017 adopted the revised proposal. The reform hinges on high-level targets for reducing staff numbers in central government allowing for wage increases.

- the poor health outcomes are linked to the low public expenditure, while other European Union (EU) countries with similarly modest spending per capita have better results. This underlines the need to both expand public health services and increase their efficiency.

To perform the structural reforms, Latvia receives significant EU investments. Latvia has requested technical support from the Structural Reform Support Service (SRSS) to help implement reforms in various areas such as public administration, growth and business environment, public financial management, health and the financial sector. In particular, the SRSS provides support for improving tax administration, increasing the cost-effectiveness and access to healthcare, developing Latvian capital markets, and providing antimoney laundering training. At the same time, Latvia is a beneficiary of significant European Structural and Investment Funds (ESI Funds) support and can receive up to EUR 5.6 billion until 2020. Latvia has also received support from the Youth Employment Initiative to combat youth unemployment. Latvia is advancing the take up of the European Fund for Strategic Investments (EFSI). More specifically, 6 projects involving Latvia have been approved so far under the Infrastructure and Innovation Window (including 3 multi-country projects), amounting to 
EUR 164 million in European Investment Bank (EIB) financing under the EFSI. In addition, funding under Horizon 2020, the Connecting Europe Facility and other directly managed EU funds is additional to the ESI Funds, for instance, by the end of 2017, Latvia has signed agreements for EUR 267 million for projects under the Connecting Europe Facility (European Commission, 2018).

The efficiency of investments becomes topical in circumstances of available investments and low performance effectiveness, particularly in field of health care. Latvia's health care system is under a process of unceasing reforms since 1990s, but planned outcomes are only reached partly. At the same time, comprehensible and transparent measures of efficiency of performed activities are not available. Taking into account the actuality of structural reforms in health care of Latvia and strictly limited recourses allocated from the public budget, the authors define the aim of this research as evaluation of opportunities to provide a model for assessment of efficiency of health care system in the context of performed reforms.

For more detail investigation of theoretical background and practical applicability, the tasks of this research are defined as follows:

1) identify the most suitable elements of management theories applicable to the health care organisation;

2) examine health care management as an executive part of public administration;

3) evaluate the cohesiveness of health care management with risk management approach;

4) create the levels-based model for evaluation of efficiency of health care organisation; and

5) test the created model on measuring efficiency of health care in Latvia.

To achieve the aim of the research, the methods of theoretical research (literature analysis, content analysis, and electronic resources analysis) are used alongside the methods of empirical research (data collection methods: document analysis and database statistical analysis). For data processing and analysis, the statistical analysis methods (comparison, grouping, calculation of average quantities) and methods of forecasting are used. The theme of this research touches upon a sphere, which has not been sufficiently investigated in Latvia yet and presents a pilot-evaluation of the health care reform and its efficiency measuring.

The authors assume health care management as a part of public administration, taking into account that the public expenditures for health care compose more than $11 \%$ of the general government budget expenditures (Ministry of Finance, 2018). Population health represents one of the factors influencing the development of all branches of economy to support work efficiency. In this research, particular attention is paid to the period from 1990s up to now considering that in this period the reform of the health care system was assumed which is still continuing. 


\title{
RESEARCH RESULTS AND DISCUSSION
}

\author{
Theoretical BACKgROUND
}

\section{Overview of management theories applicable to the health care organisation}

In this research, the authors look at four major approaches to management theory: classical, quantitative, behavioural, and contemporary (Figure 1).

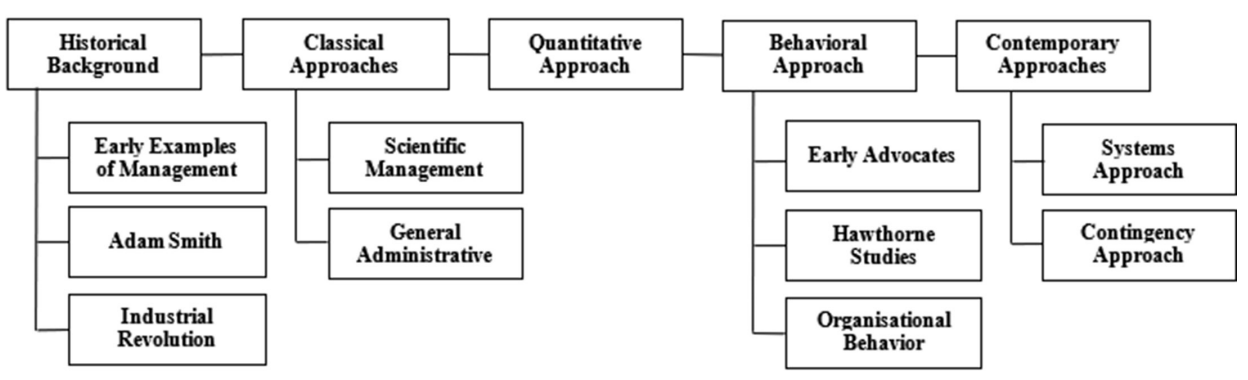

Source: Robbins S. P. and Coulter M., 2016

Fig. 1. Major Approaches to Management

The greatest contributions to organisational theory have been collected with the focus on task performance and structure. In the following, four different theoretical contributions, which are central to the understanding of organisations that focus on task performance and structure, are reviewed with theoretical schools:

- Taylor - Scientific Management

- Fayol-Administrative Theory

- Weber - Bureaucracy and Organisational Structure

- Simon-Administrative Behaviour

The first formal studies of management, often called the classical approach, emphasised rationality and making organisations and workers as efficient as possible. Two major theories comprise the classical approach: Scientific Management and Administrative Theory. Scientific Management originated in the beginning of the $20^{\text {th }}$ century, and Frederick Winslow Taylor was the primary contributor. Scientific Management was based on an idea of systematisation where attempts were made to enhance the efficiency of procedure to best effect via scientific analyses and experiments. Taylor believed that it was possible to prescribe the processes that resulted in maximum output with a minimum input of energy and resources (Lægaard and Bindslev, 2006). Frederick W. Taylor became the 'father' of Scientific Management, studied manual work using scientific principles - that is, guidelines for improving production efficiency - to find the one best way to do those jobs. His most prominent followers and important 
contributors to Scientific Management theory were Frank and Lillian Gilbreth. The Gilbreths' primary contribution was finding efficient hand-and-body motions and designing proper tools and equipment for optimizing work performance (Robbins and Coulter, 2016). Nowadays managers use the concepts of Scientific Management to analyse basic work tasks to be performed, use time-and-motion study to eliminate wasted motions, hire the best-qualified workers for a job, and design incentive systems based on output.

The two most important contributors to General Administrative Theory were Henri Fayol and Max Weber. Around the same time as Taylor, Henri Faylor developed another approach within the rational perspective, which inverts the focus of Scientific Management, and, administrative processes rather than technical processes were rationalised. The administrative principles in the form of the management's hierarchical pyramid structure were to function as the basis of the part of the organisation that involved activities, i. e. a top down approach. Several different theoretical contributions to this administrative approach are concerned with overall principles - coordination and specialisation. Thus, coordination is based on a hierarchical pyramid structure in which the members of the organisation are linked to each other, and there must be clarity in the administrative structure. Specialisation, on the other hand, is concerned with ways of grouping the organisation's activities most effectively in separate entities. As it appears from both coordination and specialisation, they express a high degree of formalisation, which is one of the principal themes of the rational perspective (Lægaard and Bindslev, 2006). Fayol described the practice of management as something distinct from accounting, finance, production, distribution, and other typical business functions. His belief that management was an activity common to all business endeavours, government, and even the home led him to develop 14 principles of management - fundamental rules of management that could be applied to all organizational situations (Robbins and Coulter, 2016). Faylor and others were pioneers in the creation of Administrative Theory, and therefore, they were later subjected to criticism for over-simplifying administrative conditions. The main critic was Herbert Simon who later represented the theory of Administrative Behaviour. Simon forced the field into a period of introspection that eventually led to a countertrend that embraced the importance of valuebased issues for the profession (Handbook of Organizational Theory, 2006).

Max Weber is described as a 'father' of sociology, and he developed an understanding and theory of Bureaucracy and Organisational Structure. Weber is different from Taylor and Fayol in that he has a broader approach to organisations as he includes the social and historical perspective. He believes that the understanding of organisations and their structure can be found in the historical context, and he develops a normative ideal for bureaucracy, which is reflected in his view of e.g. the public employee. According to Weber, the public employee must act as if the superior's interests were his own and thus stay in his bureaucratically assigned role. Bureaucracy must consist of neutral professional public employees so that the organisational hierarchy can function as smoothly 
and effectively as possible. Additional to the emphasis on the hierarchical aspect of obedience, Weber perceives goal-rational action as the optimum form of behaviour. Acting goal-rationally is an ideal approach, which considers goals, means and side effects. These three factors must be weighted in relation to each other; means in relation to goals, goals in relation to side effects, and finally, different possible goals in relation to each other. In doing so, factors of emotion and value are not included in decision-making but are underlying rationality perceptions with a lower degree of rationality (Lægaard and Bindslev, 2006). In modern society, General Administrative Theory is used to perform the functions of management and structure the organizations so that resources are used efficiently and effectively.

The quantitative approach involves applications of statistics, optimization models, information models, and computer simulations to management activities. Today's managers use the quantitative approach, especially when making decisions, as they plan and control work activities such as allocating resources, improving quality, scheduling work, or determining optimum inventory levels. Total quality management - a management philosophy devoted to continual improvement and responding to customer needs and expectations - also makes use of quantitative methods to meet its goals (Robbins and Coulter, 2016).

Although a number of individuals in the early twentieth century recognised the importance of people to an organisation's success, four stand out as early advocates of the organisational behavioural approach: Robert Owen, Hugo Munsterberg, Mary Parker Follett, and Chester Barnard. Their contributions were varied and distinct, yet all believed that people were the most important asset of the organisation and should be managed accordingly. Their ideas provided the foundation for such management practices as employee selection procedures, motivation programs, and work teams. The Hawthorne Studies dramatically affected management beliefs about the role of people in organisations, leading to a new emphasis on the human behaviour factor in managing (Robbins and Coulter, 2016).

Herbert Simon has attempted to clarify the above-mentioned characteristics of the rational perspective - goal specificity and formalisation - and explain their connection to rational behaviour (1976). He moves in an individualpsychological level in that he criticises the individual understanding, which lies in e.g. Taylors's studies. It is a matter of studies of organisations from the macro level. This conforms to the historical development in the use of analysis levels where the social-psychological level was the one used most frequently in early organisational research. Simon's criticism of Taylor's studies means a clash with the 'Economic Man', who Simon makes more human by stating that even though the individual seeks his own interests, he is not always of his basic interests. Therefore, the individual no longer experiences complete rational action but only limited rational action. Simon emphasises that it is easy to criticize the rational model for its lack or realism. The problem is not to find points to object to in the 
model, but to proceed in the understanding of what happens in organisations when decisions are made. The behavioural patterns that is characteristic for Simon is the behavioural model, which he designs and terms 'Administrative Man' (limited rational action) in contrast to 'Economic Man' (rational action). Limited rationality includes the two key elements in the rational system - the existence of specific objectives, which reduce of the individual's decision opportunity in choice situations via setting of objectives on several levels, and formalised structure (Lægaard and Bindslev, 2006).

Drawing on logical positivism, Simon and others strengthened the belief among many that public administration could and would become a true science by following empiricist principles. This belief has manifested itself in a variety of ways, including an emphasis on behavioralist social science in the 1950s and 1960s, and an emphasis on policy analysis, cost-benefit analysis, management science, and systems analysis in the 1960s and 1970s. While this faith in the development of an empirical science of public administration is perhaps somewhat diminished nowadays, it remains an important element in the thinking of mainstream public administration (Handbook of Organizational Theory, 2006). The behavioural approach has largely shaped in management of contemporary organisations and created base for many current theories of motivation, leadership, group behaviour and development, and other behavioural issues.

Most of the earlier approaches focused on managers' concerns inside the organisation. Starting in the 1960s, management researchers began to look at what was happening in the external environment outside the boundaries of the organisation. Two contemporary approaches - systems approach and contingency approach - are part of these management perspectives. Systems theory is a basic theory in the physical sciences, but had never been applied before to organised human efforts. A system is a set of interrelated and interdependent parts arranged in a manner that produces a unified whole. The two basic types of systems are closed and open. Closed systems are not influenced by and do not interact with their environment. In contrast, open systems are influenced by and do interact with their environment (Robbins and Coulter, 2016). Actually, when an organisation is described as a system, it means open system. What this means is that as managers coordinate work activities in the various parts of the organisation, they ensure that all these parts are working together so the organisation's goals can be achieved.

The early management theorists came up with management principles they generally assumed to be universally applicable. Later research found exceptions to many of these principles. For example, bureaucracy is desirable in many situations, but in other circumstances, other structural designs are more effective. Management is not (and cannot be) based on simplistic principles to be applied in all situations. Different and changing situations require managers to use different approaches and techniques. The contingency approach (sometimes called the situational approach) assumes that organisations are different, face different situations (contingencies), and require different ways of managing. Managers 
must look at their situation and determine that if this is the way situation is, then this is the best way to manage. Management researchers continue working to identify the situational variables, such as organisation size, routineness of task technology, environmental uncertainty and individual differences (Robbins and Coulter, 2016).

\section{Health Care management as an executive part} OF PUBLIC ADMINISTRATION

Initially the term 'health care system' should be specified, that in accordance with the definition of World Health Organisation (WHO) 'consists of all organisations, people and actions whose primary intent is to promote, restore or maintain health' and its goals are 'improving health and health equity in ways that are responsive, financially fair, and make the best, or most efficient, use of available resources' (World Health Organisation, 2007). In referring to the individual components of health systems, this research uses the current WHO 'Framework for Action' on health systems, which describes six clearly defined Health System Building Blocks that together constitute a complete system. Therefore, it could be assumed, that the health care organisation operates as an open system (Figure 2).

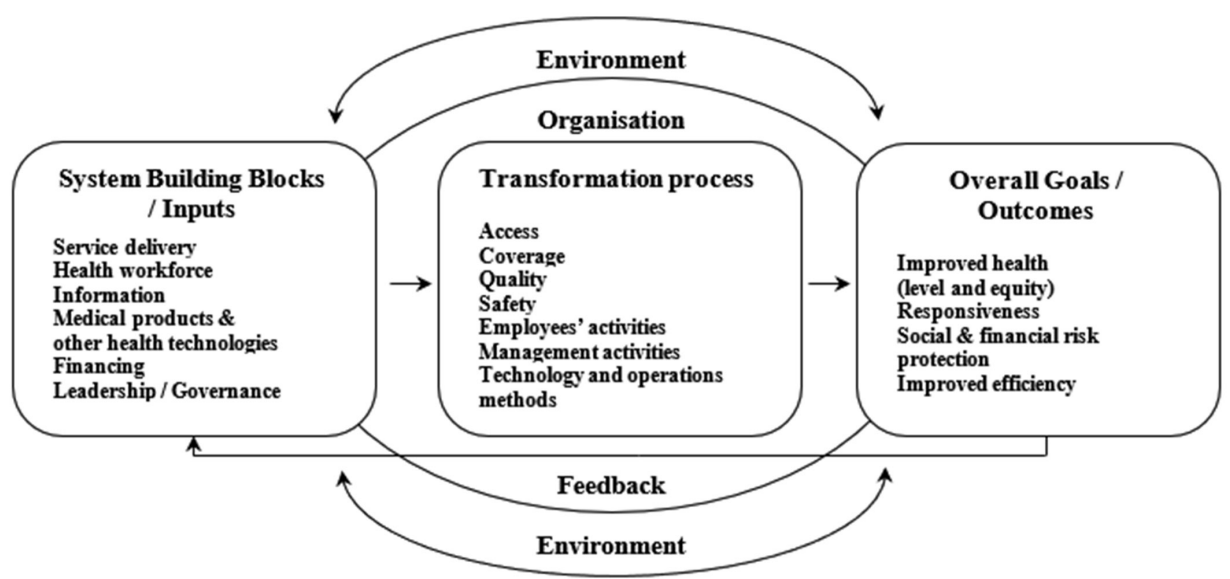

Source: authors' construction based on (World Health Organisation, 2007; Robbins and Coulter, 2016)

Fig. 2. Health care organisation as an open system

The health care organisation, as an open system, takes in inputs (resources) from the environment and transforms or processes these resources into outputs that are distributed into the environment. The organisation is 'open' to and interacts with its environment. In this way, managers can recognise that organisations are not self-contained, but instead rely on their environment for essential inputs and as outlets to absorb their outputs. 
The World Health Organisation defines the System building blocks (inputs) of a health care organisation as follows (World Health Organisation, 2007):

- Service delivery: including effective, safe, and quality personal and nonpersonal health interventions that are provided to those in need, when and where needed (including infrastructure), with a minimal waste of resources;

- Health workforce: responsive, fair and efficient given available resources and circumstances, and available in sufficient numbers;

- Health information: ensuring the production, analysis, dissemination and use of reliable and timely information on health determinants, health systems performance and health status;

- Medical technologies: including medical products, vaccines and other technologies of assured quality, safety, efficacy and cost-effectiveness, and their scientifically sound and cost-effective use;

- Health financing: raising adequate funds for health in ways that ensure people can use needed services, and are protected from financial catastrophe or impoverishment associated with having to pay for them;

- Leadership and governance: ensuring policy frameworks combined with effective oversight, coalition building, accountability, regulations, incentives and attention to system design.

The building blocks alone do not constitute a system, any more than a pile of bricks constitutes a functioning building. It is the multiple relationships and interactions among the blocks - how one affects and influences the others, and is in turn affected by them - that convert these blocks into a system.

One of the most topical of the System building blocks is medical and health technologies, as these technologies require substantial financial recourses. The International Network of Agencies for Health Technology Assessment (INAHTA) offers one of the widely used definitions of health technology: 'Any intervention that may be used to promote health, prevent, diagnose or treat disease, or for rehabilitation or long-term care. This includes pharmaceuticals, devices, procedures and organisational systems used in health care' (Network of Agencies, 2017). The European Union official network for evaluation of health technologies EUnetHTA has defined health technology assessment (HTA) as 'a multidisciplinary process that summarizes information about the medical, social, economic and ethical issues related to the use of a health technology in a systematic, transparent, unbiased, robust manner. Its aim is to inform the formulation of safe effective, health policies that are patient focused and seek to achieve best value' (EUnetHTA, 2008).

The international professional organisations, academies and national competent authorities currently use different approaches for covering of health technologies' taxonomy and therefore different scope of the HTA. These dissimilarities make it harder to compare the HTA results, its completeness and quality. 
Theoretically is defined that the health technologies include pharmaceuticals, medical devices, diagnostic and treatment methods, rehabilitation and prevention methods; as well as organisational, financial, delivery and support systems. At the same time, the HTA is defined as a multidisciplinary field of policy analysis, which studies medical, social, ethical and economic implications of development, diffusion and use of health technology. Practically, by international survey results it can be observed that HTA is applied mostly for pharmaceuticals and medical devices, which is defined as a comprehensive national HTA system. However at these systems there are lack of methods and policy analysis, which studies medical, social, ethical and economic implications, for instance, of specific health care financing and managerial models, as well as the impact of interaction the HTA system's parts.

Overall goals (outcomes) of health care organisation are defined in different documents produced by the World Health Organisation and the Word Bank, as follows:

- Improved health: health is a state of complete physical, mental and social well-being and not merely the absence of disease or infirmity (World Health Organisation, 1946). Universal health coverage (UHC) means that all people and communities can use the promotive, preventive, curative, rehabilitative and palliative health services they need, of sufficient quality to be effective, while also ensuring that the use of these services does not expose the user to financial hardship (World Health Organization and the International Bank for Reconstruction and Development / The World Bank, 2017).

- Responsiveness: in the case of the health system, the main aim is to produce a health in the population that is equitably distributed. However, the population also expects the health system to treat people with dignity. Within this framework, health system responsiveness was given the formal definition of 'the ability of the health system to meet the population's legitimate expectations regarding their interaction with the health system, apart from expectations for improvements in health or wealth' (World Health Organisation, 2000). The population's legitimate expectations were defined in terms of international human rights norms and professional ethics. The concept of responsiveness was developed as part of World Health Organisation's broader conceptual framework on health systems developed in 2000, which identified three focuses for health system goals: health, responsiveness and financing fairness. The framework's underlying reasoning behind including responsiveness was that as a social system, the health system, like other social systems (e. g. justice, education), was expected by its populations to meet a core goal plus, common social goals expected of all social systems, in addition to their main aim.

- Social and financial risk protection: social protection in scope of health care mostly associated with previously mentioned equity and social goals; 
financial protection is at the core of universal health coverage and one of the final coverage goals. Health financing policy directly affects financial protection. Financial protection is achieved when direct payments made to obtain health services do not expose people to financial hardship and do not threaten living standards (World Health Organization, 2000).

- Improved efficiency: The World Health Report (2010) estimated that from $20 \%$ to $40 \%$ of all health spending is wasted through inefficiency. Reducing this waste would greatly improve the ability of health systems to provide quality services and improve health. Investing these resources more wisely can help countries move much closer to universal coverage without increasing spending (World Health Organization, 2010).

Concerning financial risk protection, the authors assume to evaluate the risk management approach, as it provides the conceptual framework for risk management process and levels of responsibility (Figure 3).

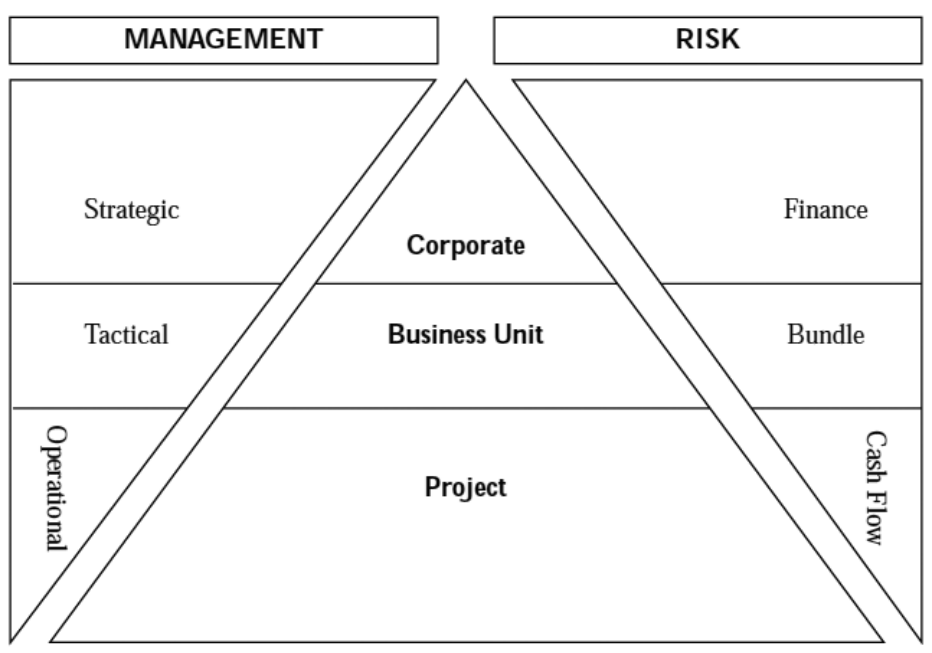

\section{RISK ANALYSIS}

Source: Merna and Al-Thani, 2008

Fig. 3. The risk management process

Figure 3 conceptualises the risk management process. Risk management looks at risk and the management of risk from each organisational perspective, namely strategic, tactical and operational perspectives. Organisations have different levels with different objectives. Risks specific to each level should be identified using risk identification techniques and then analysed with purpose to reduce negative impact. Risk management should be a continuous process over the whole life cycle of the investment. Many project management procedures place considerable stress on the quantification of risk. However, at the strategic 
business and corporate levels a significant proportion of the risks are not quantifiable and thus favour less formal risk management. The emphasis placed on the quantification processes often leads to a failure at the corporate and strategic business levels to prompt a manager to take account of other types of risk more difficult or impossible to quantify (Merna and Al-Thani, 2008).

In light of project management, project risk is an uncertain event or condition that, if it occurs, has a positive or a negative effect on a project's objectives. This definition includes two key dimensions of risk: uncertainty and effect on a project's objectives. The uncertainty dimension may be described using the term 'probability' and the effect may be called 'impact' (though other descriptors are possible, such as 'likelihood' and 'consequence'). The definition of project risk also encompasses uncertain events, which could have a negative effect on a project's objectives, as well as those, which could have a positive effect. These two types of risk are called, respectively, threats and opportunities. This allows for the gain of synergies and efficiencies such as addressing both in the same analyses and coordinating the responses to both if they overlap or can reinforce each other (Project Management Institute, 2009).

According to the authors, the risk management approach is applicable for health care organisations, and financial risk is the responsibility of the strategic level of management, however, as mentioned previously, at the strategic and corporate levels a significant proportion of the risks are not monitored and thus favour a less formal risk management. At the same time, the strategic level of health care management and its decision-making provides the most significant impact to society.

Concerning to the item of improved efficiency, the authors assume to look the health care organisation and its management as an executive part of public administration. One of the imperatives of public administration is the achievement of efficiency at all levels. Public organisations are responsible to provide the necessary public goods and services to the citizens without any discrimination specifically based on affordability. Therefore, the multidimensional objectives of public administration demand that performance not only is limited to costbenefit analysis, but also incorporates the essential element of providing value to citizens.

A common definition of efficiency is embedded in more technical terms whereby it is a measure of the ratio of output to input. This is also known as technical efficiency and it obscures that efficiency in public administration is to be assessed in the light of public values. Efficiency as signifying the necessity of having capable operative administrative agents constitutes one of the, if not the, core value of the field (Rutgers and van der Meer, 2010); it is acceptable when one is dealing within a system of well-quantifiable measures of inputs and outputs. However, efficiency takes on a completely new perspective when one tries to study it in an environment of traditionally measured quantities in a system that is heavily based on values, inspirations, and human perceptions. This addition of 
'value' dimension gives a unique perspective to efficiency in public administration (Manzoor, 2014).

For comparison and goal setting, an organisation needs to evaluate its performance; measurement of performance has always related to its mission and activities, as well as the environment in which it is operating. It is fairly straightforward for business organisations to measure performance because the sole criterion is well defined and easy to measure goal of maximizing profit. This is based on monetary terms and as such provides a clear and simple basis for comparison and evaluation. In contrast, performance measures for an organisation whose purpose of existence is other than profit are open for deliberation. Although inputs may generally take monetary form, the outputs are not readily measurable in monetary terms and further have a value base where profit maximization may not be the ultimate goal for existence. This is reason enough to be careful in exploring the concept of efficiency in the world of public administration (Manzoor, 2014). This approach is completely applicable for evaluation of health care organisation, as it takes significant monetary resources without clear and measurable evidence of results.

From a theoretical view, there exist two very distinct schools of thoughts on the notion of efficiency in public administration domain. First view is based on the previously mentioned Max Weber's theory of Bureaucracy and Organisational Structure and argues that public organisations are structured as bureaucracies, which provides rational and efficient organisation structures to public organisations. In contrast, the other school of scholars sees public organisations as pursuing multiple value-based goals in a democratic system (Manzoor, 2014).

Founder of the Scientific management approach Fredrick Winslow Taylor on one hand placed emphasis on quantity of output with time and motion study, and finding one best way of doing the job. On the other hand, it also called for dividing the responsibilities between management and workers. Therefore, some later researchers regarded scientific management as 'paradigmatic call for efficiency', further emphasizing its impact on public administration in the form of 'New Public Management (NPM) as Neo-Taylorism' (Rutgers and van der Meer, 2010).

Additionally, the Organisation for Economic Co-operation and Development (OECD) proposes the impact analysis as a component of the policy or programming cycle in public management, where it can play two roles (Organisation for Economic Co-operation and Development, 2014):

- Ex ante impact analysis. This is part of the needs analysis and planning activity of the policy cycle. It involves doing a prospective analysis of what the impact of an intervention might be, so as to inform policymaking - the policymaker's equivalent of business planning;

- Ex post impact assessment. This is part of the evaluation and management activity of the policy cycle. Broadly, evaluation aims to understand to what extent and how a policy intervention corrects the problem it was intended to address. 
Impact assessment focuses on the effects of the intervention, whereas evaluation is likely to cover a wider range of issues such as the appropriateness of the intervention design, the cost and efficiency of the intervention, its unintended effects and how to use the experience from this intervention to improve the design of future interventions.

\section{PRACTICAL APPLICATION}

Taking into account the results of theoretical research, the authors propose the levels-based model for evaluation of efficiency of health care organisation, as an open system (Figure 4).

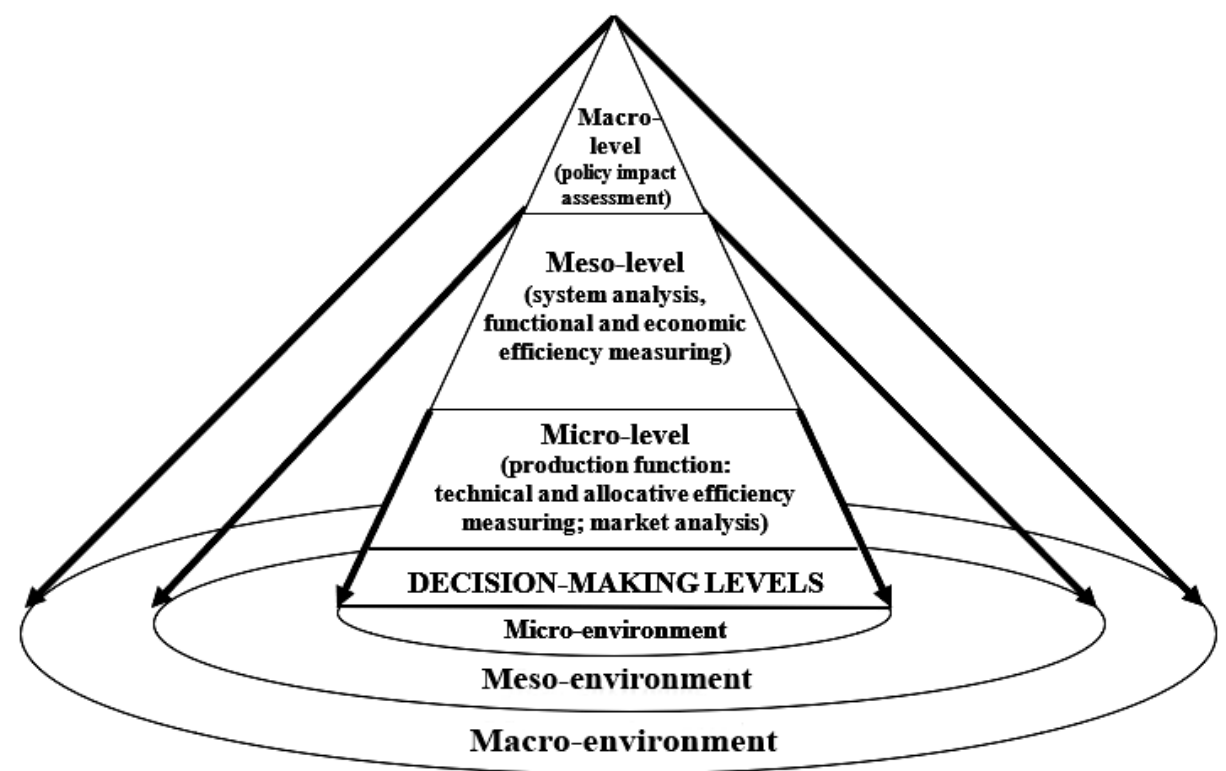

Source: authors' construction

Fig. 4. Three-level performance evaluation model for assessment of health care system

In the authors' opinion, the above described management theories are more or less applicable to a health care organisation. Each of the four approaches contributes to overall understanding of management, but each is also a limited view of what it is and how to best practice it. The Scientific Management approach, founded by Frederick Winslow Taylor, was based on an idea of systematisation where attempts were made to enhance the efficiency of procedure to best effect via scientific analyses and experiments. This approach is suitable for research of health care, as a medicine is mostly based of experiments and scientific analyses. The Administrative Theory, contributed by Henri Fayol, provides the principles 
of rationality, coordination and specialisation, with management's hierarchical pyramid structure, is applicable to a health care organisation due to high level of responsibility in this kind of management. Thus, coordination is based on a hierarchical pyramid structure in which the members of the organisation are linked to each other, and there must be clarity in the administrative structure. Specialisation, on the other hand, is concerned with ways of grouping the organisation's activities most effectively in separate entities, e.g. specialisations of health providers and health care institutions. The theory of Bureaucracy and Organisational Structure, described by Max Weber, has provided the initial view on public administration and public servants' behaviour and measuring of public administration effectiveness and efficiency. The importance of people is completely associated with health care organisation, so the organisational behavioural approach is quite important for health care management. Herbert Simon has attempted to clarify the above-mentioned characteristics of the rational perspective - goal specificity and formalisation - and explain their connection to rational behaviour. He introduced the term of limited rationality, which includes the two key elements in the rational system - the existence of specific objectives that reduce of the individual's decision opportunity in choice situations via setting of objectives on several levels, and formalised structure with emphasis on policy analysis, cost-benefit analysis, management science, and systems analysis. The quantitative approach, including applications of statistics, optimization models, information models, and computer simulations to management activities, is supportive and topical for nowadays health care organisation.

The most appropriate of the contemporary approaches for a health care organisation is a system approach, as a health care organisation represents all attributes of open system, that is, as described in above. Open systems are influenced by and do interact with their environment. It should be taking into account, that a health care organisation, especially, its highest level of management and its decision-making, significantly influences the society and real patients, so the risk management approach and 'value' dimension of efficiency in public administration, as well as the OECD approach for impact assessment, were emphasised in this research.

Taking into consideration the previously mention arguments, the authors created a three-level performance evaluation model for assessment of the efficiency of health care organisations, based on macro-level evaluation (policy impact assessment), meso-level evaluation (system analysis, functional and economic efficiency measuring) and micro-level evaluation (production function, allocative and technical efficiency measures) (Figure 4). The appropriate measures of the macro impact results, policy outcomes and performance outputs should be defined to evaluate the efficiency of health care system. As it shown in Figure 4, the higher level management's decisions influence a larger part of environment and provides more sufficient risks for society in case of inappropriate decisions. 
In the scope of delimitation of this research, the authors provide some not expanded examples of assessment on macro-level, meso-level and evaluation of applicable methods of analyses for micro-level. In assessment of macro-level particular attention is paid to the period from 1991 up to now considering that in this period the reform of the health care system was assumed which is still continuing. The problems are identified that interfere with effective and rational implementation of reform's goals, which were sufficiently logically defined at the beginning of this process. At the Table 1, the three initial principal policyplanning documents of 1990s related to the health care financing in Latvia are

Table 1

Examples of the principal policy-planning documents and legislative acts of 1990s drafted in the course of the health care reform related to the sources of health care financing in Latvia, and their current stage of implementation

\begin{tabular}{|c|c|c|}
\hline $\begin{array}{l}\text { Policy-planning } \\
\text { documents and } \\
\text { legislative acts }\end{array}$ & Strategic directions & $\begin{array}{l}\text { Current stage of } \\
\text { implementation }\end{array}$ \\
\hline 1 & 2 & 3 \\
\hline $\begin{array}{l}\text { Resolution No. } 146 \\
\text { of } 24 \text { December } 1992 \\
\text { by the Ministry of } \\
\text { Welfare of Latvia 'On } \\
\text { development and } \\
\text { operation of the Cash } \\
\text { Office }\end{array}$ & $\begin{array}{l}\text { Based on this order, a Cash Office of the Ministry } \\
\text { of Welfare (from } 1996 \text { to } 1999 \text { - State Sickness } \\
\text { Fund; from } 1999 \text { to } 2009 \text { - State Agency of } \\
\text { Mandatory Health Insurance; from } 2009 \text { to } \\
2011 \text { - Health Payment Centre) was established in } \\
\text { 1993, with the principal purpose of its operation } \\
\text { to lead the healthcare financing reform in the } \\
\text { country in a methodical and organisational way. } \\
\text { Municipal cash offices were formed in all districts } \\
\text { of the country at the same time. }\end{array}$ & $\begin{array}{l}\text { The National Health } \\
\text { Service, which was } \\
\text { established on the base } \\
\text { of Health Payment } \\
\text { Centre in 2011, does not } \\
\text { have functions to lead } \\
\text { the healthcare financing } \\
\text { reform. }\end{array}$ \\
\hline $\begin{array}{l}\text { Basic principles 'On } \\
\text { health care financing' } \\
\text { prepared by the } \\
\text { Ministry of Welfare } \\
\text { and adopted by the } \\
\text { Cabinet of Ministers on } \\
1 \text { November } 1994\end{array}$ & $\begin{array}{l}\text { Equal access to healthcare services regardless of } \\
\text { the social status and income of an individual was } \\
\text { laid down as the main principle. According to } \\
\text { the basic principles, it was planned to introduce } \\
\text { a health tax already in } 1995 \text {, payable in equal } \\
\text { parts (three per cent of the taxable income of an } \\
\text { employee) by the employee and the employer; it } \\
\text { was also planned to ensure that voluntary health } \\
\text { insurance would cover } 20 \% \text { of the total costs of } \\
\text { healthcare. }\end{array}$ & \multirow{2}{*}{$\begin{array}{l}\text { State-funded health } \\
\text { services are set to be } \\
\text { linked to the payment of } \\
\text { social contributions from } \\
\text { 2019. Population groups } \\
\text { excluded from the full } \\
\text { access to public services } \\
\text { can make voluntary } \\
\text { health contributions. } \\
\text { The standard social } \\
\text { security contribution } \\
\text { rates are increased by } \\
0.5 \% \text { for both employees } \\
\text { and employers, resulting } \\
\text { in a } 1 \% \text { rate allocated } \\
\text { to healthcare as an } \\
\text { additional financial } \\
\text { resource. }\end{array}$} \\
\hline $\begin{array}{l}\text { Concept 'On State } \\
\text { mandatory health } \\
\text { insurance' prepared by } \\
\text { the Ministry of Welfare } \\
\text { and adopted by the } \\
\text { Cabinet of Ministers on } \\
28 \text { May } 1996\end{array}$ & $\begin{array}{l}\text { According to the concept, state mandatory } \\
\text { health insurance was seen as a component of } \\
\text { the state social insurance system, the purpose of } \\
\text { the introduction of which is to enable residents } \\
\text { to receive quality healthcare services so as to } \\
\text { create preconditions for a gradual improvement } \\
\text { of the health condition of the population and } \\
\text { stabilisation of the demographic situation. }\end{array}$ & \\
\hline
\end{tabular}

Source: authors' collection based on (Ministry of Welfare, 1992; Cabinet of Ministers, 1994; Cabinet of Ministers, 1996) 
indicated. The ex-post evaluation shows that the defined goals, e.g., equal access to healthcare services regardless of the social status and income of an individual; introduction a health tax already in 1995; and state mandatory health insurance as a component of the state social insurance system, come into force more than 20 years later - in 2018 and 2019.

These data lead to the considerations about temperate low functional effectiveness of the Latvian health care reform. At the same time, the reform shows the substantial productive efficiency in scores of the institutional reorganisation by decreasing the number of subordinated institutions and employees, but these issues are not evaluated in detail within scope of the research paper. Taking into account that the health care is only one of the mechanisms to achieve the public health goals, the authors assume that the macro impact results are specified for public health, the policy outcomes are determined to the health care, as well as the pharmacy, while the performance's out-puts are representative for detail analysis of each level.

To test the applicability of the model for assessment of meso-level, the authors choose the reimbursement system for medicinal products and medical devices. The procedures for reimbursement are a set of measures that provide patients with an opportunity to acquire medicinal products and medical devices, the expenditures for the acquisition of which are completely or partially covered by funds from the state budget for the current year. At the Table 2 the state budget allocated for reimbursement of expenditures of medicinal products; number of patients

Table 2

State budget allocated for reimbursement of expenditures of medicinal products; number of patients treated; average cost per patient; and reimbursed medicines consumption data in Latvia, 2013-2016

\begin{tabular}{|c|c|c|c|c|c|c|c|}
\hline & 2013 & $\begin{array}{c}\text { Increase, } \\
\%\end{array}$ & 2014 & $\begin{array}{c}\text { Increase, } \\
\%\end{array}$ & 2015 & \begin{tabular}{|c|} 
Increase, \\
$\%$
\end{tabular} & 2016 \\
\hline 1 & 2 & 3 & 4 & 5 & 6 & 7 & 8 \\
\hline 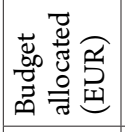 & 11369391.7 & 4.60 & 118928460.7 & 4.52 & 124302576.7 & 16.52 & 144834157.5 \\
\hline 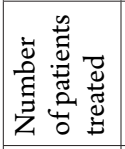 & 576290 & 4.24 & 600696 & 3.95 & 624437 & 6.16 & 662889 \\
\hline 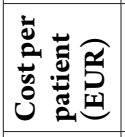 & 197.286 & 0.35 & 197.984 & 0.54 & 199.063 & 9.76 & 218.489 \\
\hline 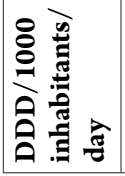 & 423.028 & 6.46 & 450.351 & 5.56 & 475.375 & 5.87 & 503.303 \\
\hline
\end{tabular}

Source: authors' calculations based on National Health Service of Latvia database 
treated; average cost per patient; and reimbursed medicines consumption data in Latvia, 2013-2016, are indicated. The authors made calculations based on the National Health Service database, choosing the trends of the average cost per patient and reimbursed medicines consumption data as the most appropriate indicators of system's efficiency for testing of the model in limitation of the research scope. The analysis of medicines consumption was performed using the World Health Organisation recommended ATC/DDD classification system that allows standardising the categorisation of medicines and using the international units of medicines consumption - DDD (Defined Daily Doses)/1000 inhabitants/day.

The data of the Table 2 shows that the state budget allocated for the reimbursement system, as well as the number of patients treated, increase annually. The indicator of efficiency - cost per patient - was relatively stable in 2014 and 2015, but significantly increased in 2016. At the same time, the consumption of medicines in natural units increased almost two times lower, that indirectly indicates, that significantly more expensive medicines were used in 2016, in comparison with 2015. These testing considerations lead to assumption that reimbursement system of medicines and medical devices shows the tendency to move towards technical efficiency, rather than total economic efficiency (technical and allocative efficiency), as the treatment alternatives (nutrition programs, physician's time by consultation, complementary therapy etc.) are not sufficiently taken into account, but treatment alternatives are not observed in detail within the scope of this research.

For assessment of micro-level, the authors propose production function, technical efficiency and allocative efficiency with further derivatives (Figure 5).

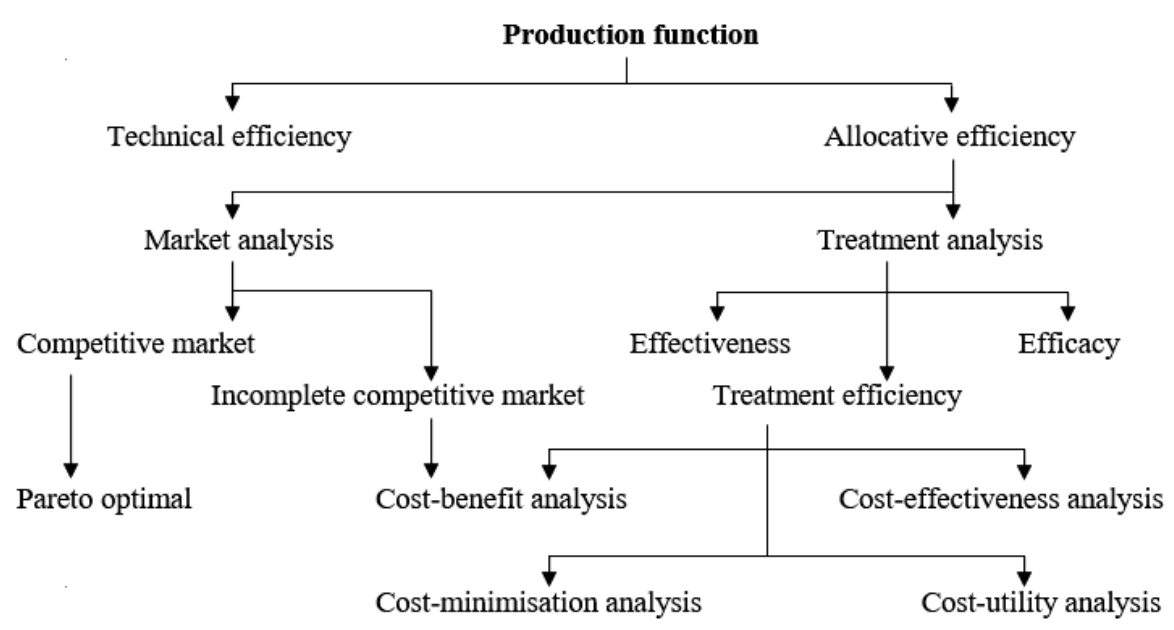

Source: authors' construction

Fig. 5. Authors' proposed the most applicable methods of analyses the efficiency at the micro-level of the health care system 
The allocative efficiency in health economics is also associated with the market efficiency and effectiveness of the treatment process. There are no perfect competition market conditions for health care products and services, so it is necessary to use the additional methods of economic analysis, such as the costbenefit analysis, which is one of the most appropriate methods in consideration to the health care.

\section{CONCLUSIONS}

1. Europe's health systems face several challenges, such as population ageing, a rise in chronic conditions, declining workforces and increasing cost pressures. Health systems research can help decision-makers address the challenges they face and provide scientific evidence to inform policies and practices, thus resulting in more effective policy measures and health care systems that are both efficient and responsive to the needs of European citizens.

2. The health care management can be investigated as a part of public administration, taking into account that the public expenditures for health care take significant amount of the general government budget. Population health represents one of the factors influencing the development of all branches of economy due to support the work efficiency.

3. The management theories are applicable to health care organisation. The Scientific Management approach, founded by Frederick Winslow Taylor, was based on an idea of systematisation where attempts were made to enhance the efficiency of procedure to best effect via scientific analyses and experiments. This approach is suitable for research of health care, as a medicine is mostly based of experiments and scientific analyses. The Administrative Theory, contributed by Henri Fayol, provides the principles of rationality, coordination and specialisation, with management's hierarchical pyramid structure, is applicable to health care organisation due to high level of responsibility in this kind of management. The theory of Bureaucracy and Organisational Structure, described by Max Weber, has provided the initial view on public administration and public servants' behaviour and measuring of public administration effectiveness and efficiency. The importance of people is completely associated with health care organisation, so the organisational behavioural approach is quite important for health care management. Herbert Simon has attempted to clarify the above-mentioned characteristics of the rational perspective goal specificity and formalisation - and explain their connection to rational behaviour. The quantitative approach, including applications of statistics, optimization models, information models, and computer simulations to management activities, is supportive and topical for nowadays health care organisation.

4. The most appropriate of the contemporary approaches for health care organisation is system approach, as health care organisation represents all 
attributes of open system. The systems approach says that an organisation takes in inputs (resources) from the environment and transforms or processes these resources into outputs that are distributed into the environment. This approach provides a framework to help managers understand how all the interdependent units work together to achieve the organisation's goals.

5. The risk management approach is applicable for health care organisation, and financial risk is responsibility of the strategic level of management, however, at the strategic and corporate levels a significant proportion of the risks are not monitored and thus favour less formal risk management. At the same time, the strategic level of health care management and its decision-making provides the most significant impact to society.

6. The efficiency in public administration is more than a technical relationship between resources and output; it has another dimension that incorporates outputs in relation to values and accountability as an inherent quality of governance. Furthermore, efficiency in private organizations is merely an indicator of revenue maximization; however, it may not be a viable indicator to access performance based on revenue generation in public organisations.

7. The ex-post pilot-evaluation of the Latvian health care reform leads to the conclusion of its temperate low functional effectiveness, particularly taking into consideration the long exemption period to reach a number of planed measures and some inconsistencies in the formulation of the expected outcomes. At the same time, the reform shows the substantial productive efficiency in scores of the reorganisation of the institutional framework.

8. The testing results lead to the assumption, that the reimbursement system of medicines and medical devices shows a tendency to move towards technical efficiency, rather than total economic efficiency (technical and allocative efficiency), as the treatment alternatives (nutrition programs, physician's time by consultation, complementary therapy etc.) are not sufficiently taken into account, but treatment alternatives are not observed in detail within the scope of this research.

\section{PROPOSALS AND RECOMMENDATIONS}

1. The health system research tools should be used more effectively to evaluate the performance of the health care tasks, as well as the results of the health care systems reforms. Taking into account the results of theoretical research, the authors propose the levels-based model for evaluation of efficiency of health care organisation, as an open system. The authors created a three-level performance evaluation model for assessment of the efficiency of a health care organisation, based on macro-level evaluation (policy impact assessment), meso-level evaluation (system analysis, functional and economic efficiency measuring) and micro-level evaluation (production function, allocative and technical efficiency measures, market analysis). 
2. The appropriate measures of the macro impact results, policy outcomes and performance outputs should be defined to evaluate the efficiency of health care system. To develop a common approach and avoid misunderstandings it could be recommended that:

- firstly, to consider the possibility to define the medical technologies as a subgroup of health technologies, which are directly used in treatment process (pharmaceuticals, medical devices, diagnostic and treatment methods) and for which full Health technology assessment (HTA) are applied;

- secondly, to clarify the separation of diagnostic, medical and surgical procedures from pharmaceuticals and medical devices, as there is not a common approach for their assessment separately or as a part of medical procedure (for pharmaceuticals) or diagnostic and surgical procedure (for medical devices); and

- thirdly, to continue the development of specific HTA methodologies for assessment of health care financing, delivery, and managerial models, prevention activities and complementary medicine, rehabilitation programs and long-term care, and for other health technologies' subgroups.

The common approach for health technologies' taxonomy and appropriate assessment methods could soften the HTA challenges and improve the credibility and value of its results.

3. The open systems are influenced by and do interact with their environment. It should be taking into account, that the health care organisation, especially, its highest level of management and its decision-making, significantly influences the society and real patients, so the risk management approach and 'value' dimension of efficiency in public administration, as well as the impact assessment, should be emphasised. The higher-level management's decisions influence larger part of environment and provides more sufficient risks for society in case of inappropriate decisions.

The theme of this research touches upon the sphere which has not been sufficiently investigated in Latvia yet and presents suggestions with regard to substantiated use of the health system research principles for decision-making in questions related to organisation and financing of the national health care system.

\section{REFERENCES}

European Commission, 2010. Europe 2020 - a strategy for smart, sustainable and inclusive growth. [Online]. Available at: http://eur-lex.europa.eu/LexUriServ/LexUriServ. do? uri=COM:2010:2020: FIN:EN:PDF [Accessed 12 January 2018].

European Commission, 2018. Country Report Latvia 2018. Accompanying the document 'Communication from the Commission to the European Parliament, the Council, the European Central Bank and the Eurogroup 2018 European Semester: Assessment of progress on structural reforms, prevention and correction of macroeconomic imbalances, and results of in-depth reviews under Regulation 
(EU) No 1176/2011', Brussels, 7.3.2018 SWD (2018) 212 final. [Online] Available at: https://ec.europa.eu/info/sites/info/files/2018-european-semester-countryreport-latvia-en.pdf [Accessed 10 March 2018].

European Network for Health Technology Assessment (EUnetHTA), 2008. Work Package 8. EUnetHTA Handbook on Health Technology Assessment Capacity Building. Barcelona (Spain): Catalan Agency for Health Technology Assessment and Research. Catalan Health Service. Department of Health Autonomous Government of Catalonia. [Online] Available at: http://www.inahta.org/ wp-content/themes/inahta/img/eunethta_wp8_hb_hta_capacity_building1. pdf [Accessed 9 January 2018].

Handbook of Organizational Theory and Management : the Philosophical Approach / [edited by] Thomas D. Lynch, Peter Cruise - 2nd ed. / Public Administration and Public Policy, 116, 2006. U.S.: Taylor \& Francis Group, LLC. ISBN 0-8493-3834-4

International Network of Agencies of Health Technology Assessment, 2017. Definition of Health Technology Assessment. Stockholm (Sweden): International Network of Agencies of Health Technology Assessment INAHTA. [Online] Available at: http://www.inahta.org/GO-DIRECT-TO/Members [Accessed 9 January 2018].

Lægaard, J. and Bindslev, M., 2006. Organizational theory. Ventus Publishing ApS. ISBN: 87-7681-169-7.

Manzoor, A., 2014. A Look at Efficiency in Public Administration: Past and Future. [Online] Available at: http://journals.sagepub.com/doi/full/10.1177/ 2158244014564936 [Accessed 9 January 2018].

Merna, T. and Al-Thani, F., 2008. Corporate Risk Management, 2nd Edition. England: John Wiley \& Sons Ltd. ISBN 978-0-470-51833-5

Project Management Institute, 2009. Practice Standard for Project Risk Management. USA: Project Management Institute. ISBN: 978-1-933890-38-8

Robbins, S. P. and Coulter, M., 2016. Management, 13th ed., England: Pearson Education. ISBN: 978-0-13-391029-2

Rutgers, M. R. and van der Meer, H., 2010. The Origins and Restriction of Efficiency in Public Administration: Regaining Efficiency as the Core Value of Public Administration. [Online] Available at: http://journals.sagepub.com/doi/abs/ 10.1177/0095399710378990 [Accessed 9 January 2018].

The Cabinet of Ministers of the Republic of Latvia, 1994. Basic principles on health care financing. [Online] Policy planning documents database. Available at: http:// polsis.mk.gov.lv/documents/325 [Accessed 12 January 2018].

The Cabinet of Ministers of the Republic of Latvia, 1996. Concept on State mandatory health insurance. [Online] Policy planning documents database. Available at: http://polsis.mk.gov.lv/documents/329 [Accessed 12 January 2018].

The Cabinet of Ministers of the Republic of Latvia, 2016. Declaration on the Intended Activities of the Cabinet of Ministers of Latvia. [Online] Available at: https://www. mk.gov.lv/sites/default/ files/editor/deklaracija_en.pdf [Accessed 12 January 2018].

The Ministry of Finance of the Republic of Latvia, 2018. Interactive general governmental budget 2018. [Online] Available at: https://www.fm.gov.lv/valstsbudzets/ [Accessed 11 January 2018].

The Ministry of Welfare of the Republic of Latvia, 1992. Resolution No. 146 on development and operation of the Cash Office. The unpublished materials of the Ministry of Welfare.

The Organisation for Economic Co-operation and Development (OECD), 2014. What is impact assessment? Document based on: OECD Directorate for Science, 
Technology and Innovation (2014), 'Assessing the Impact of State Interventions in Research - Techniques, Issues and Solutions', unpublished manuscript. [Online] Available at: https://www.oecd.org/sti/inno/What-is-impact-assessment-OECD Impact.pdf [Accessed 11 January 2018].

World Health Organisation, 1946. Definition of Health. Preamble to the Constitution of WHO as adopted by the International Health Conference, New York, 19 June 22 July 1946; signed on 22 July 1946 by the representatives of 61 States (Official Records of WHO, no. 2, p. 100) and entered into force on 7 April 1948.

World Health Organisation, 2000. The world health report 2000 - Health systems: improving performance. Geneva: World Health Organisation. ISBN 92-4-156198-X.

World Health Organisation, 2007. Everybody's Business: Strengthening Health Systems to Improve Health Outcomes: WHO's Framework for Action. Geneva: World Health Organisation. ISBN 978-92-4-159607-7.

World Health Organisation, 2010. The world health report: health systems financing: the path to universal coverage. Geneva: World Health Organisation. ISBN 978-92-4156402-1.

World Health Organisation and the International Bank for Reconstruction and Development / The World Bank, 2017. Tracking universal health coverage: 2017 global monitoring report. Geneva: World Health Organisation. ISBN 978-92-4151355-5. 


\title{
CHARACTERISTICS OF CONSUMER PROTECTION AND PUBLIC MANAGEMENT IN LATVIA
}

\author{
ZANDA DĀVIDA
}

\begin{abstract}
The rapid, diverse and complexity of current economic development has led to a need for a high level of consumer protection. This is emphasised both in the regulations of European Union law (including the provision of consumer protection as on one of two sectoral rules to be taken into account in the implementation of European Union policies and activities), both in the European Union case law and in the Member States, including the Latvian regulatory framework. The topicality of the research is justified by the facts and indications that testify that the competent authorities of Latvia cannot effectively ensure a high level of consumer protection. In turn, it distorts the European Union internal market, in particular the Latvian market, competition and aggravates the state's economic situation. The aim of the research is to evaluate the effectiveness of the competent authorities of Latvia in the field of protection of unfair commercial practises and to make recommendation for its improvement. In order to achieve the aim, the author will analyse the European Union and Latvian regulatory framework, scientific literature, the practice and statistics of the European Union and Latvia. As a result of the research, the author concludes that the legislator has to assess the need to expand the rights of the competent authorities, while the competent authorities should consider the possibility of examining current practices. The results of the study can be used in practice for improving the efficiency of public management in protecting consumers in the field of unfair commercial practices.
\end{abstract}

Key words: Latvia, unfair commercial practices, management, consumer, public management

JEL code: K42, P46, H83

\section{INTRODUCTION}

Over time, the market economy has become even more complicated. On the one hand, the modern market provides consumers with a wide range of opportunities, but on the other hand, it is difficult for consumers to understand it. The average consumer is no longer able to trace the market development process and innovations; hence, it has led to imbalances between the trader and the consumer. Over the years' consumer protection policies and regulations have developed, because of need for an effectively and fairly functioning market, which works as a benefit to all members of society and the economy of the state. 
The European Union (EU) and its Member States have also introduced a strong consumer protection regulation, which should ensure a high level of consumer protection in the European single market. Previous practice shows that there are problems with the application of a high level of consumer protection regulation in Latvia. Namely, the competent national authorities of Latvia are not able to effectively ensure a high level of consumer protection in the field of unfair commercial practices. It significantly reduces the competitiveness of the Latvian economy in the European single market, distorts the single market, and causes losses to consumers, traders and the state. The topicality of the article problem question is confirmed by the statistical data analysed in the article and the practice of state administration institutions and courts. For example, the number of consumer complaints in state institutions and courts has recently grown significantly. Only 23 percent of the applicants could have obtained help from the Consumer Rights Protection Centre of Latvia (CRPC) to resolve the dispute. Consumers are consulting very little about commercial practices, e-commerce and advertising issues, compared to other types of counselling. Consumers actively use alternatives to protect their rights, such as mass media, rather than turning to authorities for help or defending their rights in court.

The aim of the article is to evaluate the effectiveness of the competent state administration institutions in the field of protection of unfair commercial practices, as the hypothesis is nominated follows: the competent Latvian authorities are not able to effectively ensure a high level of consumer protection in the field of unfair commercial practices. Consequently, by failing to meet the requirements of the EU as set out in the Directive 2005/29/EC of the European Parliament and of the Council of 11 May 2005 concerning unfair business-toconsumer commercial practices in the internal market and amending Council Directive 84/450/EEC, Directives 97/7/EC, 98/27/EC and 2002/65/EC of the European Parliament and of the Council and Regulation No 2006/2004 of the European Parliament and of the Council (Unfair Commercial Practices Directive). In order to achieve the goal, the author will analyse the EU and Latvian regulatory law, scientific research literature, the EU Courts and the Latvian courts case law, as well as authorities practice and statistics. Consequently, a wide range of scientific research methods will be used, including analytical, comparative, grammatical, teleological, systemic, inductive and deductive methods. Within the framework of the work, conclusions and recommendations for possible solutions to the problem in the article will be presented. The results of the research can be used in practice, with aim to improve authorities - public management efficiency of protection of consumers in the field of unfair commercial practices.

\section{RESEARCH RESULTS AND DISCUSSION}

The beginnings of the consumer culture are sought back in time before the era, but as Benöhr (2013, pp. 10-11) points out consumer protection as a systematic 
policy goal is a recent phenomenon that began globally, only in the middle of the twentieth century. Urgent needs of consumer protection appear with scandals that have increased in mass production and health fields. Today's economic development is very fast. The market is complex and rich with information. This is one of the reasons that caused imbalances between traders and consumers. Consequently, today the market is no longer able to function without a specific regulation that creates an equal relationship between the consumer and the trader.

Also, the public regulation of the market in Europe has developed incrementally for many centuries now under a rich variety of motivating forces, therefore, EU policies and activities must be conducted with due respect for a series of EU fundamental values. Groups such as consumers and workers must be protected from imperfections and inequities of un regulated markets (Weatherill, 2017). Over time, the EU has developed several documents that emphasise the need to ensure a high level of consumer protection. It is the basis for the development of an efficient, fair and right European single market. Article 12 of the Treaty on the Functioning of the European Union stresses in particular the protection of consumers by providing that "consumer protection requirements shall be taken into account in defining and implementing other Union policies and activities". Namely, only two areas (environment and consumer protection) in EU law have sectoral protection, which points to the sensitive nature of these areas, the need for special protection and the importance of society. In addition, Article 38 of the Charter of Fundamental Rights provides that "Union policies shall ensure a high level of consumer protection". This reaffirms the particular role of consumers in the legal system, which points to the fact that some of the consumer rights edges have human rights features. For example, Benöhr (2013, p. 46) states that consumer rights of access to justice are recognised as new generation of human rights. Summarising the above and looking at consumer rights in terms of unfair commercial practices, it can be concluded that the overarching objective of the Unfair Commercial Practices Directive is to introduce and ensure a high level of consumer protection throughout the Member States. Weatherill (2017, pp. 160) states that "the commitment to a high level of protection has played a prominent role in the Court's interpretation of relevant legislative texts, sometimes in the form of remarkable ambitions. Consumer protection is one of several vividly illustrative areas". The Court of Justice of the European Union (ECJ) has also reiterated its strong position on a high level of consumer protection on several occasions. In the case of Nemzeti Fogyasztóvédelmi Hatóság v UPC Magyarország Kft. (2015), the ECJ noted that, in relation to a trader, the consumer is in a weaker position, especially with regard to the level of information, in that the consumer must be considered economically weak and less experienced in legal matters than the other party to the contract.

The author concludes that with strict regulation and requirements for a high level of consumer protection, it is not enough, as it is also necessary to 
provide effective application in practice. The ECJ in the case of Köck (2015) and Sánchez Morcillo and Abril García (2014) have assessed the implementation of the principle of effectiveness in individual cases. The importance of principle is also highlighted in Recitals 18 and 22 in the Preamble to the Unfair Commercial Practices Directive, which states that it is appropriate to protect all consumers from unfair commercial practices. Persons or organisations considered to have a legitimate interest in the matter must have legal remedies for initiating proceedings against unfair commercial practices either in a court or in an administrative authority, which is competent to decide on complaints or to initiate appropriate legal proceedings.

The adoption of the Unfair Commercial Practices Directive enabled Member States to exercise freedom of choice in order to adapt remedies to the needs and characteristics of a particular country. In Latvia, persons who have a legitimate interest in combating unfair commercial practices can do this in three ways. First, under the Article 15 of Unfair Commercial Practice Prohibition Law (UCPP) persons may propose investigation of unfair commercial practices in the CRPC or in the Health Inspectorate (HI). Secondly, it is possible to bring a claim in court in accordance with Article 1 of the Civil Procedure Law. Thirdly, to bring a claim of damages in the court in accordance with Article $4 .{ }^{1}$ of the UCPP. From the systemic and practical point of view, considering these three possibilities, it is concluded that this is incomplete and difficult for the average consumer. For the CRPC or the HI to initiate a case of unfair commercial practices, the competent authorities shall take into account the criteria set out in the UCPP. Namely: 1) the supervisory priorities of the institution; 2) the impact on consumer collective interests and 3) the balance of supervision. These criteria are very general; there are no publicly available guidelines about it, statistical or other sources that would meet the criteria for the application of the system to assess the relevance and validity of specific cases. Consequently, criteria (especially the first two, that is, the authorities in their supervisory priorities and impact on the collective interests of consumers) are the basis of failing unfair commercial practice case, despite the fact that in this case is recognized direct evidence of the fact of unfair commercial practices.

The statistics of the CRPC shows that the number of complaints submitted to the institution increases year by year (Figure 1). However, despite the fact that unfair commercial practices are one of the most common and complicated violations of consumer law, only 9-11\% of applications received in the CRPC (in the period from 2013 to 2017) were about unfair commercial practices and only 1-2\% of the CRPC consultations (in the period from 2013 to 2017) have been about unfair commercial practices. The correlation between these statistics makes the facts ascertained in practice even more complicated and more controversial. For example, in the decision of September 7, 2017 No. 22-pk the CRPC concludes that at least 3000 consumers have been affected by the unfair commercial practices of a particular trader, but only 44 applications have been received in the CRPC for this trader. Consequently, 


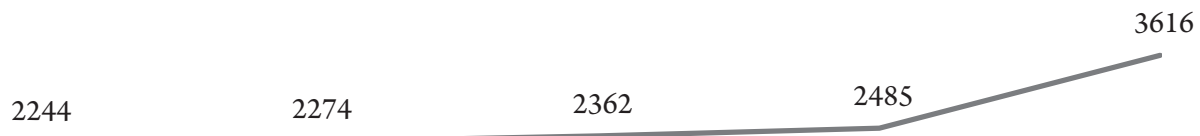

Source: author's construction based on CRPC statistical data

Fig. 1. Number of applications and complaints received by the CRPC in 2013-2017

it can be concluded that at least 2956 consumers have not tried to go to the institution to defend their rights.

In the period from 2013 to 2017, the CRPC has been able to help the applicants find a positive solution in 17-23\% of cases. 2016 and 2017 the CRPC has not adopted any individual consumer-friendly decision. In turn, the $\mathrm{HI}$ is evaluated commercial practices only within the framework of the advertising of medicinal products, although the institution's competence for narrow interpretation in practice does not have a regulatory basis. Consequently, it can be concluded that the activities of the authorities are not aimed at assessing and providing assistance to individual consumers in cases of unfair commercial practices. Authorities only deal with general unfair commercial practices that are part of the list of supervisory priorities of the institutions or have a significant impact on the collective interests of consumers. Such management is in contradiction with EU consumer policy and the requirements for a high level of consumer protection, in which all consumers should be protected from unfair commercial practices. Partially it can be interpreted as violation of human rights to a fair trial. In particular, this is worth considering in the context of the ways of protecting persons who are entitled to fight against unfair commercial practices in Latvia. Namely, effective defences in the area of unfair commercial practices of competent authorities reveal significant weaknesses and problems. Consequently, in this situation, it is particular important for consumers to provide an effective alternative to the possibility of protecting their interests. In Latvia this alternative way is court, but there the question arises - is a court in Latvia an effective way for consumers to protect their interests? If answer is no, then effective public management of competent authorities becomes particularly important.

For the average consumer to sue a trader in accordance with Article 1 of the Civil Procedure Law (for example, a claim for termination of unfair commercial practices) or to bring a claim for damages in the face of unfair commercial practices in accordance with Article $4 .{ }^{1}$ of the UCPP is very complicated. Namely, 
disputes of this kind are settled in a civil - general procedure, where one of the basic principles of the process is the adversarial principle. This means that the consumer (the economically weaker party compared to the trader) must prove unfair commercial practices, which is a very complicated legal institution. Even lawyers often misunderstand unfair commercial practice. Namely, the consumer needs to be specialised in law, needs to draw up a legally grounded application, needs to be able to obtain and submit evidence for the court, pay court's costs and state's fees. Consequently, it can be concluded that the judicial protection of court is not effective for protecting consumers from unfair commercial practices, in particular where the harm done to a particular consumer is negligible compared to the likely costs and risks of litigation. In practise, there have been cases where one consumer loss is some euros, but the trader has done unfair commercial practice not only to one consumer, but also to hundreds of consumers. Therefore, total loss for consumers and the traders' benefit is several thousand euros, which affect the Latvian economy and market enough in a negative way.

Considering, that judicial court protection for consumers in the area of unfair commercial practices is not effective, the effectiveness of public administration in protecting consumers from unfair commercial practices must be recognised as being of paramount importance and vital to create stability and equilibrium in the single market. It should be concluded that for many years the effectiveness of this public administration has not been consistent with the successful development of the national economy of Latvia. It has a lot of problems and consequences. Firstly, consumers are not defending their rights in the field of unfair commercial practices because they are not aware of their rights and do not recognise unfair commercial practices which are directed against them. At the same time, consumers do not see the results of defence, because there is no practice and there is a lack of culture to "break for their - consumers' rights". Consumers are passive market players. The complicated and expensive legal court process also contributes to this issue. Secondly, this creates for traders a sense of impunity that encourages the launching and continuation of unfair commercial practices, as the actual finding of litigation for unfair commercial practices is insignificant, especially compared to the trader's economic benefits of making unfair commercial practices. In practice, there are cases where unfair commercial practices are implemented not by small market participants, but also by large, publicly respected and important traders in the Latvian economy. In particular, these traders are those who continue to pursue unfair commercial practices, ignoring consumers' complaints and penalties imposed by the supervisory authority, since the economic benefits of unfair commercial practices outweigh all fines. A striking example is the Air Baltic case (2007), in which the trader in the airline ticket system commissioned consumers on trader's web site (and thus with active consumer activity) to deactivate the trader's automatic activation option for the purchase of additional services along with the airline ticket. In this way, consumers wishing to buy only an airline ticket, 
eventually purchased additional services such as a flight date/time exchange guarantee, which they did not want to buy. The trader's profits from consumers in the practice of unfair commercial practices against them were so motivating that the trader for several months did not comply with the CRPC decision, but paid after each seven days a compulsory cash for non-execution of the decision. The pressure of society, politicians and the mass media caused the suppression of unfair commercial practices by traders. Thirdly, unfair commercial practices pose significant losses to consumers, distort the market, undermine fair competition, and undermine the state's economic position and the effective functioning of the single European market. Consumers do not trust to the European internal market, therefore, consumers of other countries refuse to buy goods and services in Latvia.

Allowing unfair commercial practices is undervalued damage to the Latvian economy. Consequently, it can be concluded that effective management of the public sector in this field is one of the most appropriate and main means to prevent unfair commercial practices in Latvia. The current functioning of the supervisory authorities has not been effective enough to ensure a high level of consumer protection. Thus, the hypothesis in the article is confirmed. In order to tackle the protracted problem of combating unfair commercial practices in the public sector, it is encouraged to extend the supervisory authority and monitor past practices.

At present, the Consumer Rights Protection Law and the UCPP are translated and adapted so that the supervisory authority has the power to make binding decisions in the event of unfair commercial practices only if unfair commercial practices are part of the supervisory priorities or have a significant impact on the collective interests of consumers. Consequently, supervisors should be given the power to make binding decisions even if only one consumer is affected. At the same time, the need to monitor supervisory practices should be considered, bearing in mind that supervision should not be based solely on the institution's priorities and on the collective interests of consumers, but the criterion "impact on collective consumer interests" should be used to determine severity of penalty rather than initiating/not initiating a case. If the authority does not make a decision on consumer claim, the authority should give a first (non-binding) assessment of the compliance of commercial practice. This would provide the consumer with an opportunity to assess his or her ability to pursue his or her defence in court. At present, consumers without specific knowledge cannot understand whether they are generally exposed to unfair commercial practices. In turn, HI should review a narrow view of unfair commercial practices, as well as clearly delineate the competences of the HI and CRPC.

The above-mentioned suggestions to improve institutional efficiency can be taken in the short term and do not ask for a substantial increase in funding. In addition, those improvements do not need to match with EU institution and some of them do not need for amendment for Latvian law. Therefore, the results 
of the research can be used in practice, with aim to improve public management efficiency of protection consumers' rights in the field of unfair commercial practice.

\section{CONCLUSIONS, PROPOSALS, RECOMMENDATIONS}

1. Some of the consumer rights boundaries have human rights features, therefore consumer law enforcers must be particularly careful and correct with such sensitive rights.

2. In Latvia, persons who have a legitimate interest in combating unfair commercial practices can do this in three ways: 1) may propose investigation of unfair commercial practices in the CRPC or the HI; 2) may bring a claim in court in accordance with general procedure; 3) may bring a claim of damages in court in accordance with UCPP. These ways are incomplete and difficult for the average consumer.

3. To initiate a case of unfair commercial practices, the competent authorities (the CRPC and the HI) shall take into account the criteria set out in the UCPP: 1) the supervisory priorities of the institution; 2) the impact on consumer collective interests; 3 ) the balance of supervision. These criteria are very general and there are no publicly available guidelines about it, therefore there is no clear system of applying criteria. Consequently, criteria are the basis of failing unfair commercial practice cases, despite the fact that in this case is recognised direct evidence of the fact of unfair commercial practices.

4. The correlation between authorities' statistics and practice makes it even more complicated and more controversial. The activities of the authorities are not aimed at assessing and providing assistance to individual consumer in case of unfair commercial practices. Authorities only deal with general unfair commercial practices that are part of the list of supervisory priorities of the institutions or have a significant impact on the collective interests of consumers. Such management is in contradiction with EU consumer policy and the requirements for a high level of consumer protection. Partially it can be interpreted as violation of human rights to a fair trial.

5. A court in Latvia is not effective way for consumers to protect their interests (it is because of adversarial principle, which is too complicated to realise by the average consumer), therefore effective public management of competent authorities is particularly important.

6. The competent authorities of Latvia are not able to effectively ensure a high level of consumer protection in the field of unfair commercial practices.

7. The ineffectiveness of the authorities has produced the following consequences: 1) consumers are not defending their rights; 2) traders experience a sense of impunity; 3) unfair commercial practices pose significant losses to consumers, distort the market, undermine fair competition, undermine the 
state's economic position and the effective functioning of the single European market; and 4) consumers do not trust to the European and Latvian internal market.

8. To resolve the Latvian problem of ineffective authorities: 1) supervisors should be given the power to make binding decisions even if only one consumer is affected; 2) the criterion "impact on collective consumer interests" should be used to determining a penalty severity rather than initiating/not initiating a administrative case; 3 ) if the authority refuse to make binding decision on consumer claim, the authority should give a non-binding assessment of the compliance of commercial practice; and 4) HI should review a narrow view of unfair commercial practices, as well as clearly delineate the competences of the $\mathrm{HI}$ and the CRPC.

\section{REFERENCES}

Benöhr, I., 2013. EU Consumer Law and Human Rights. Oxford: Oxford University Press.

Case C-169/14, Sánchez Morcillo and Abril García, judgment of 17 July 2014.

Case C-206/11, Köck, judgment of 17 January 2013.

Case C-388/13, Nemzeti Fogyasztóvédelmi Hatóság v UPC Magyarország Kft., judgment of 16 April 2015.

Consumer Rights Protection Center of Latvia, 2007. Lēmums patēēēāju tiesību pārkāpuma lietā Nr. 33-pt. [pdf]. Riga: Consumer Rights Protection Center of Latvia. Available at: http://www.ptac.gov.lv/sites/default/files/lemums_nr.33_ pt_2007.06.07_as_air_baltic_corporation.pdf [Accessed 22 June 2018].

Weatherill, S., 2007. The Internal Market as a Legal Concept. Oxford: Oxford University Press. 


\title{
EMPLOYEE ENGAGEMENT ANALYSIS EVALUATION - APPROACHES, RESULTS AND CHALLENGES ${ }^{1}$
}

\author{
LAURA KERŠULE
}

\begin{abstract}
The rapid development of modern telecommunication technologies in the world, as well as in Latvia has led to struggle and close contest for skilled personnel in today's telecommunication industry. Telecommunication companies demand that their staff would be professionally well educated, creative, efficient, motivated and loyal. Preparation of good practitioners able to perform activities for creation of competitive products and services takes time and huge effort. Companies in the conditions of intensive competition are interested to keep their professional staff for company development. Recent scientific findings are that it is important to engage employees to keep them satisfied with their work and be loyal to the company. Research methods used: scientific literature review, survey of employees (608 responses). For survey a 7-point scale, which is ranging from 1 - strongly disagree and 7 - strongly agree is used to indicate which engagement instruments are applied in current working place. For data analysis the main indicators of descriptive statistics: indicators of central tendency or location and indicators of variability were used, as well as cross-tabulations. For deeper analysis of the survey results statistical hypothesis testing with t-test for checking differences in answers of male and female respondents was used. Multivariate analysis: factor analysis for dimension reduction, regression, correlation analysis, and variance analysis for checking differences in answers of respondents by age group, by education level, by work experience and by time worked in respective company.
\end{abstract}

Key words: Latvia, employee engagement, motivation, management, human capital, commitment in the work place

JEL code: M54, M52, M50

\section{INTRODUCTION}

Recent economic development has generated new requirements for the management of companies and organisations to keep skilled personnel in the company. Researchers of company management have found it important to pay attention to company management for the development of human resources and engagement. In recent scientific publications by many company management researchers (Cameron, Dutton, Quinn, 2003), particular attention has been paid 
to the aspect that company human capital is an important long-term advantage in competition as this kind of capital - human capital - is more and more difficult to copy by competitors in other companies and organisations. Thus recognising that company human resources are a sustainable competitive advantage (Macey, Schneider, 2008). These aspects are of research interest for researchers worldwide.

\section{THEORETICAL BACKGROUND}

Taking into account that employees spend a significant part of their lifetime at their workplace it is increasing understood by organisation leaders of the role of human factors for sustainable development of the company in the aspect of excellence (Caza, Cameron, 2008). Several researchers have confirmed a logical connection - if human capital is well and professionally on a high level managed (Swart, 2007) that it influences positively the results of the work of the organisation (Foster, 2010; Peterson, Luthans, Avolio, Walumbwa, Zhang, 2011). This is the way in which human capital in organisations is becoming more and more important as it is important to do the work with less human resources and companies, as well as several organisations, need motivated employees (Bal, Jansen, Velde, Lange, Rousseau, 2010) who are able and willing to involve their resources such as time and energy in their work. Taking into account the above, it is important for the organisation management to adapt in new conditions. It is important to revise processes, structure and the system of entrepreneurship, but the most important is to change the working style, as well as attitude and behaviour.

One of those new attitudes is employee engagement, which has become among the most important aspects in company management together with keeping employees in the company and their loyalty and has becoming among the biggest challenges organisations (Aithal, Kumar, 2015) are facing in this decade. In a practical sense, it means that employee engagement (Albrecht, Bakker, Gruman, Macey, Saks, 2015; Woerkom, Oerlemans, Bakker, 2016) is closely related with company performance indicators, but in theoretical prospective researchers have taken this concept as one of those factors, which helps to develop new view on theories of effective management. In scientific publications, there exist numerous definitions of employee engagement (Lodahl, Kejner, 1965); the important part of this concept is employee feelings, psychological presence at work and close involvement and connection with the organisation. Psychological presence is defined as an employee engagement condition (Kumar, Pansari, 2014), demonstrating engaged behaviour, for example, performing and doing more, as well as fulfilling tasks with enthusiasm and without the stress (Kahn, 1990). Psychological presence in to a large extent is influenced by employee role models, which involves also a feeling of security - to do at all and to what extent an employee feels secure (Cropanzano, Wright, 2001) by realising himself/herself and showing strength and to what extent an employee devotes 
himself/herself to work and identifies with the working role (Kahn, 1990; Schaufeli, Salanova, Gonzalez-Roma, Bakker, 2002).

In general, changes in the external environment has created new approaches for the management of employees, which researchers have characterised as psychologization of the workplace (Schaufeli, 2013; Meyer, Allen, 1997). It means to be able to manage ongoing changes in the organisation; to be able to develop and survive it is important to have ability and will of employees for psychological adaption for new conditions, as well as motivation (Cerasoli, Nicklin, Ford, 2014) and ongoing employee engagement. For example, changes require elasticity of employees, self-control, emotional intelligence. Request for excellence (Gordon, Demerouti, Bipp, Le Blanc, 2015) is in great extent related to personal initiative and different approaches for making management decisions it is required thinking on perspective (Peale, 1956), good teamwork and good and well-developed communication skills. Therefore, the essence and meaning of employee engagement it is possible to formulate as internal interest of employee to put in work additional care and contribution devoting more time, more intellectual potential and more energy (Frank, Finnegan, Taylor, 2004).

The research results (Frank, Finnegan, Taylor, 2004; Rana, Chhabra, 2011) indicate that the overall situation in economy is directly related with keeping of employees, but is not taken into account level of employee engagement. In the growing economic situation as we face right now it is possible to notice relatively low level of keeping of employees at the respective work place, but employee engagement differs in different organisations and employee segments. Taking into account forecasts on development of global and Latvia's economy it is noticeable that the demand for employees will increase and during the next years, it is expected a high level of employee rotation. Main reason, which could assist employers to keep their employees, will be abilities and skills in creation and increase of employee engagement, as well as strengthen loyalty to the respective company. In most of the research results come to similar conclusions - engaged employees are a significant source for company competitiveness.

Employee engagement as a social definition as well as a measurement concept has given a significant contribution on aspects assisting in the improvement of organisation performance indicators, as well as productivity of employees (Katou, Budhwar, 2015; Sumanth, 1998; Tarafdar, Tu, Ragu-Nathan, RaguNathan, 2007), satisfaction with work (Boselie, DerWiele, 2002; Rayton, Yalabik, 2014), loyalty and motivation (Schaufeli, 2013; Vroom, 1964). Most of the research confirm a positive influence of employee engagement on productivity (Koutroumpis, 2009), rentability, attraction and keeping of employees, as well as client satisfaction and service quality (Zigarmi, Nimon, Houson, Witt, Diehl, 2009; Xanthopoulou, Bakker, Demerouti, Schaufeli, 2009). Besides that in accordance with the findings of researchers Baker and Demerouti (Bakker, Demerouti, 2008), there are at least four reasons why employee engagement is very important and necessary for employees themselves. Firstly engaged employees 
often feel positive emotions (for example, happiness, fulfilment and enthusiasm); secondly, engaged employees have better health; thirdly, engaged employees create their work resources and personal resources; and fourthly, engaged employees transfer their engagement to others.

In general, engagement in scientific publications there are used four engagement conceptual approaches and each of them stresses a different aspect of engagement: 1) engagement as an approach to satisfaction of needs and is related to performance of work role (Kahn, 1990); 2) engagement as the opposite situation of burnout (Bakker, Van Emmerik, Van Riet, 2008) where it is stressed positive side of engagement in relation to well-being of employee (Schaufeli, Salanova, Gonzalez-Roma, Bakker, 2002); 3) engagement as an effect on satisfaction with work and it's relation with findings and approaches of Harter (Harter, Schmidt, Agrawal, Plowman, 2013); and 4) engagement as a multidimensional phenomenon and it's relation with work, as well as with the organisation (Saks, 2006). The author in this research has used the multidimensional approach of engagement as this approach defines engagement wider than the other approaches and is more related with management praxis of organisations and not with psychology branch. The multidimensional approach together with an attitude (Yalabik, Popaitoon, Chowne, Rayton, 2013) component in the engagement conception integrates also a behaviour dimension. Researchers Newman and Herrison (Newman, Harrison, 2008) have differentiated also the terms work engagement and employee engagement especially stressing that the first mentioned is related with psychological experience performing work, as well as attitude and characteristics of personality, but the second means an approach of the organisation to manage its employees.

Although in the world employee engagement is topical for organisations, the surveys conducted by research agencies indicate that level of employee engagement is low (Kaliannan, Adjovu, 2015). There are many discussions (Kersule, 2011) and even confusions in this field possibly caused by misunderstandings of confirmation of engagement and the preconditions and results of engagement. Still, there does not exist a common understanding and confirmation for engagement definition and its dimensions as there are views that there are differences between practical and theoretical definitions of engagement and that could be the reason for problems in comparisons of research results.

\section{EMPIRICAL FINDINGS}

In Latvia, personnel managers in organisations have also started serious work on the evaluation of personnel or employee engagement. Serious evaluation of employee engagement as praxis for organisation management, strategy of personnel management and instrument of internal communication as one of indicators characterising organisation performance level and quality and the next critical step in deeper understanding on relationships between influencing and depending factors of engagement, as well as the choice of reasonable instruments to measure 
this influence. The author believes that a significant precondition in choice of measurement scale is to consider engagement as an activity or active behaviour of engagement not only the feeling to be engaged. Research on employee engagement is becoming wider and deeper where several and very different approaches are used, which are based on different branches, cases and even small samples are used and therefore the author considers in giving her own contribution in additional evaluation of employee engagement. For the survey conducted by the author, a 7-point scale which is ranging from 1 - strongly disagree and 7 - strongly agree is used to indicate which engagement instruments are applied in the current working place. The survey resulted in 608 respondents. The respondents were personally invited and then reminded three times to those who have not responded. The response rate was $67 \%$.

Table 1

Main indicators of descriptive statistics of evaluations by respondents for aspects related to engagement

\begin{tabular}{|c|c|c|c|c|c|c|c|c|}
\hline & & 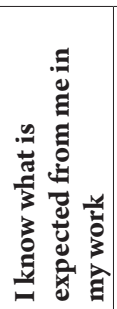 & 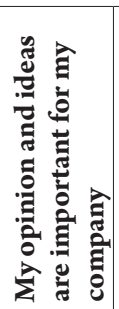 & 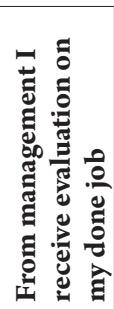 & 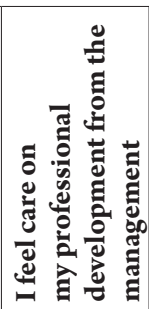 & 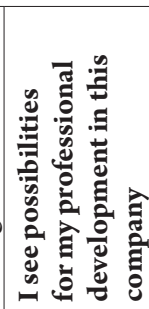 & 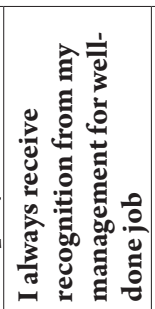 & 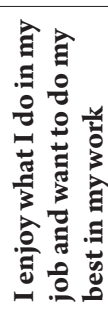 \\
\hline \multirow[t]{2}{*}{$\mathrm{N}$} & Valid & 608 & 608 & 608 & 608 & 608 & 608 & 608 \\
\hline & Missing & 0 & 0 & 0 & 0 & 0 & 0 & 0 \\
\hline \multicolumn{2}{|c|}{ Mean } & 6.02 & 5.07 & 5.10 & 5.09 & 4.94 & 4.98 & 5.86 \\
\hline \multicolumn{2}{|c|}{ Std. Error of Mean } & 0.039 & 0.053 & 0.061 & 0.056 & 0.062 & 0.061 & 0.044 \\
\hline \multicolumn{2}{|c|}{ Median } & 6 & 5 & 5 & 5 & 5 & 5 & 6 \\
\hline \multicolumn{2}{|c|}{ Mode } & 6 & $5 ; 6$ & 5 & 5 & 5 & 6 & 6 \\
\hline \multicolumn{2}{|c|}{ Std. Deviation } & 0.951 & 1.305 & 1.512 & 1.382 & 1.517 & 1.502 & 1.084 \\
\hline \multicolumn{2}{|c|}{ Variance } & 0.904 & 1.703 & 2.287 & 1.911 & 2.301 & 2.255 & 1.175 \\
\hline \multicolumn{2}{|c|}{ Range } & 6 & 6 & 6 & 6 & 6 & 6 & 6 \\
\hline \multicolumn{2}{|c|}{ Minimum } & 1 & 1 & 1 & 1 & 1 & 1 & 1 \\
\hline \multicolumn{2}{|c|}{ Maximum } & 7 & 7 & 7 & 7 & 7 & 7 & 7 \\
\hline
\end{tabular}

Source: Author's conducted survey in 2017 of employees in telecommunication sector, $n=608$, Evaluation scale 1-7, where 1 - fully disagree; 7 - fully agree

As the data of responses indicate - although there is covered a full range of the evaluation scale, the evaluations of respondents are very high: the arithmetic means are around 5 and 6 with highest average evaluation (6.02) is for statement "I know what is expected from me in my work" with mode (most often given evaluation by respondents) 6 and median 6 (half of respondents gave evaluation 6 or less and half of respondents gave evaluation 6 or more). For evaluations of respondents for this statement there is the smallest variability - smallest standard 
deviation, standard error of mean and smallest variance. Very high evaluations are also for statement "I enjoy what I do in my job and want to do my best in my work" with arithmetic mean 5.86 and mode 6 and median 6 . The relative lower evaluations of respondents are for the statement "I see possibilities for my professional development in this company" with arithmetic mean 4.94, mode 5 and median 5: they are also high taking into account that evaluations are from 1 to 7 and respondents use all possible evaluations. The evaluations of male and female respondents do differ for several analysed aspects - see Table 2.

Table 2

Main statistical indicators on evaluations by respondents in the group (female and male) statistics

\begin{tabular}{|c|c|c|c|c|c|}
\hline Evaluated Statements in Survey & Sex & $\mathbf{N}$ & Mean & Std. Deviation & $\begin{array}{l}\text { Std. Error } \\
\text { Mean }\end{array}$ \\
\hline \multirow{2}{*}{$\begin{array}{l}\text { I know what is expected from me } \\
\text { in my work }\end{array}$} & Female & 289 & 6.00 & 0.991 & 0.058 \\
\hline & Male & 319 & 6.04 & 0.914 & 0.051 \\
\hline \multirow{2}{*}{$\begin{array}{l}\text { My opinion and ideas are } \\
\text { important for my company }\end{array}$} & Female & 289 & 4.94 & 1.348 & 0.079 \\
\hline & Male & 319 & 5.19 & 1.256 & 0.070 \\
\hline \multirow{2}{*}{$\begin{array}{l}\text { From management I receive } \\
\text { evaluation on my done job }\end{array}$} & Female & 289 & 5.20 & 1.525 & 0.090 \\
\hline & Male & 319 & 5.01 & 1.497 & 0.084 \\
\hline \multirow{2}{*}{$\begin{array}{l}\text { I feel care on my professional } \\
\text { development from the } \\
\text { management }\end{array}$} & Female & 289 & 5.09 & 1.430 & 0.084 \\
\hline & Male & 319 & 5.09 & 1.340 & 0.075 \\
\hline \multirow{2}{*}{$\begin{array}{l}\text { I see possibilities for my } \\
\text { professional development in this } \\
\text { company }\end{array}$} & Female & 289 & 4.76 & 1.544 & 0.091 \\
\hline & Male & 319 & 5.09 & 1.476 & 0.083 \\
\hline \multirow{2}{*}{$\begin{array}{l}\text { I always receive recognition from } \\
\text { my management for well-done job }\end{array}$} & Female & 289 & 4.98 & 1.566 & 0.092 \\
\hline & Male & 319 & 4.98 & 1.444 & 0.081 \\
\hline \multirow{2}{*}{$\begin{array}{l}\text { I love what I do and want to do my } \\
\text { best in my work }\end{array}$} & Female & 289 & 5.85 & 1.091 & 0.064 \\
\hline & Male & 319 & 5.87 & 1.079 & 0.060 \\
\hline
\end{tabular}

Source: Author's conducted survey in 2017 of employees in telecommunication sector, $n=608$, Evaluation scale 1-7, where 1-fully disagree; 7 - fully agree

The results of the analysis indicate that in most of the evaluated aspects the male average evaluations are higher except "From management I receive evaluation on my done job" where the average valuations by female persons are bigger. For several aspects, average evaluations by male and female respondents are the same ("I feel care on my professional development from the management" and "I always receive recognition from my management for well-done job"). Although the differences in averages of evaluations by male and female respondents for some aspects are the same or alike, but testing the statistical hypothesis on differences in evaluations by male and female respondents with results included in Table 3 indicate that the average evaluations by male and female respondents does not differ statistically significant with level of significance 0.007 for analysed 
statement "I see possibilities for my professional development in this company" and with level of significance 0.020 for analysed statement "My opinion and ideas are important for my company".

Table 3

Main results on testing hypothesis on differences in evaluations by female and male respondents

\begin{tabular}{|c|c|c|c|c|c|c|c|c|}
\hline \multirow[t]{2}{*}{ Statements } & \multirow[t]{2}{*}{ Variances } & \multicolumn{2}{|c|}{$\begin{array}{c}\text { Levene's Test } \\
\text { for Equality of } \\
\text { Variances }\end{array}$} & \multicolumn{5}{|c|}{ t-test for Equality of Means } \\
\hline & & I & घं & + & t & 承节 & 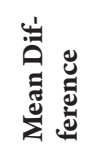 & 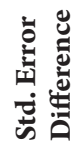 \\
\hline \multirow{2}{*}{$\begin{array}{l}\text { I know what is } \\
\text { expected from me in } \\
\text { my work }\end{array}$} & $\begin{array}{l}\text { Equal variances } \\
\text { assumed }\end{array}$ & 2.186 & 0.140 & -0.442 & 606 & 0.659 & -0.034 & 0.077 \\
\hline & $\begin{array}{l}\text { Equal variances } \\
\text { not assumed }\end{array}$ & & -0.440 & 587.037 & 0.660 & -0.034 & 0.078 & \\
\hline \multirow{2}{*}{$\begin{array}{l}\text { My opinion and } \\
\text { ideas are important } \\
\text { for my company }\end{array}$} & $\begin{array}{l}\text { Equal variances } \\
\text { assumed }\end{array}$ & 0.102 & 0.749 & -2.335 & 606 & 0.020 & -0.247 & 0.106 \\
\hline & $\begin{array}{l}\text { Equal variances } \\
\text { not assumed }\end{array}$ & & -2.327 & 589.109 & 0.020 & -0.247 & 0.106 & \\
\hline \multirow{2}{*}{$\begin{array}{l}\text { From management } \\
\text { I receive evaluation } \\
\text { on my done job }\end{array}$} & $\begin{array}{l}\text { Equal variances } \\
\text { assumed }\end{array}$ & 1.570 & 0.211 & 1.531 & 606 & 0.126 & 0.188 & 0.123 \\
\hline & $\begin{array}{l}\text { Equal variances } \\
\text { not assumed }\end{array}$ & & 1.530 & 597.787 & 0.127 & 0.188 & 0.123 & \\
\hline \multirow{2}{*}{$\begin{array}{l}\text { I feel care on my } \\
\text { professional de- } \\
\text { velopment from the } \\
\text { management }\end{array}$} & $\begin{array}{l}\text { Equal variances } \\
\text { assumed }\end{array}$ & 3.468 & .063 & -0.067 & 606 & 0.947 & -0.008 & 0.112 \\
\hline & $\begin{array}{l}\text { Equal variances } \\
\text { not assumed }\end{array}$ & & -0.067 & 590.248 & 0.947 & -0.008 & 0.113 & \\
\hline \multirow{2}{*}{$\begin{array}{l}\text { I see possibilities } \\
\text { for my professional } \\
\text { development in this } \\
\text { company }\end{array}$} & $\begin{array}{l}\text { Equal variances } \\
\text { assumed }\end{array}$ & 2.095 & .148 & -2.716 & 606 & 0.007 & -0.333 & 0.123 \\
\hline & $\begin{array}{l}\text { Equal variances } \\
\text { not assumed }\end{array}$ & & -2.710 & 593.771 & 0.007 & -0.333 & 0.123 & \\
\hline \multirow{2}{*}{$\begin{array}{l}\text { I always receive } \\
\text { recognition from } \\
\text { my management for } \\
\text { well-done job }\end{array}$} & $\begin{array}{l}\text { Equal variances } \\
\text { assumed }\end{array}$ & 3.649 & 0.057 & -0.042 & 606 & 0.967 & -0.005 & 0.122 \\
\hline & $\begin{array}{l}\text { Equal variances } \\
\text { not assumed }\end{array}$ & & -0.042 & 587.123 & 0.967 & -0.005 & 0.123 & \\
\hline \multirow{2}{*}{$\begin{array}{l}\text { I love what I do and } \\
\text { want to do my best } \\
\text { in my work }\end{array}$} & $\begin{array}{l}\text { Equal variances } \\
\text { assumed }\end{array}$ & 0.069 & 0.793 & -0.194 & 606 & 0.846 & -0.017 & 0.088 \\
\hline & $\begin{array}{l}\text { Equal variances } \\
\text { not assumed }\end{array}$ & & -0.194 & 598.834 & 0.846 & -0.017 & 0.088 & \\
\hline
\end{tabular}

Source: Author's conducted survey in 2017 of employees in telecommunication sector, $n=608$, Evaluation scale 1-7, where 1-fully disagree; 7 -fully agree 
Results on testing statistical hypotheses on differences in evaluations of respondents by age groups are included in Table 4.

Table 4

Main results on testing hypothesis evaluation differences of respondents by age groups with analysis of variance - ANOVA

\begin{tabular}{|c|c|c|c|c|c|c|}
\hline & & $\begin{array}{c}\text { Sum of } \\
\text { Squares }\end{array}$ & df & $\begin{array}{c}\text { Mean } \\
\text { Square }\end{array}$ & $F$ & Sig. \\
\hline $\begin{array}{l}\text { I know what is } \\
\text { expected from me in } \\
\text { my work }\end{array}$ & $\begin{array}{l}\text { Between Groups } \\
\text { Within Groups } \\
\text { Total }\end{array}$ & $\begin{array}{c}6.563 \\
542.159 \\
548.722\end{array}$ & $\begin{array}{c}4 \\
603 \\
607\end{array}$ & $\begin{array}{l}1.641 \\
0.899\end{array}$ & 1.825 & 0.122 \\
\hline $\begin{array}{l}\text { My opinion and } \\
\text { ideas are important } \\
\text { for my company }\end{array}$ & $\begin{array}{l}\text { Between Groups } \\
\text { Within Groups } \\
\text { Total } \\
\end{array}$ & $\begin{array}{c}18.940 \\
1014.729 \\
1033.669 \\
\end{array}$ & $\begin{array}{c}4 \\
603 \\
607 \\
\end{array}$ & $\begin{array}{l}4.735 \\
1.683\end{array}$ & 2.814 & 0.025 \\
\hline $\begin{array}{l}\text { From management I } \\
\text { receive evaluation on } \\
\text { my done job }\end{array}$ & $\begin{array}{l}\text { Between Groups } \\
\text { Within Groups } \\
\text { Total } \\
\end{array}$ & $\begin{array}{c}21.537 \\
1366.542 \\
1388.079 \\
\end{array}$ & $\begin{array}{c}4 \\
603 \\
607 \\
\end{array}$ & $\begin{array}{l}5.384 \\
2.266\end{array}$ & 2.376 & 0.051 \\
\hline $\begin{array}{l}\text { I feel care on my } \\
\text { professional devel- } \\
\text { opment from the } \\
\text { management }\end{array}$ & $\begin{array}{l}\text { Between Groups } \\
\text { Within Groups } \\
\text { Total }\end{array}$ & $\begin{array}{c}17.462 \\
1142.562 \\
1160.025\end{array}$ & $\begin{array}{c}4 \\
603 \\
607\end{array}$ & $\begin{array}{l}4.366 \\
1.895\end{array}$ & 2.304 & 0.057 \\
\hline $\begin{array}{l}\text { I see possibilities } \\
\text { for my professional } \\
\text { development in this } \\
\text { company }\end{array}$ & $\begin{array}{l}\text { Between Groups } \\
\text { Within Groups } \\
\text { Total }\end{array}$ & $\begin{array}{c}14.492 \\
1382.006 \\
1396.498\end{array}$ & $\begin{array}{c}4 \\
603 \\
607\end{array}$ & $\begin{array}{l}3.623 \\
2.292\end{array}$ & 1.581 & 0.178 \\
\hline $\begin{array}{l}\text { I always receive } \\
\text { recognition from } \\
\text { my management for } \\
\text { well-done job }\end{array}$ & $\begin{array}{l}\text { Between Groups } \\
\text { Within Groups } \\
\text { Total }\end{array}$ & $\begin{array}{c}2.347 \\
1366.454 \\
1368.801\end{array}$ & $\begin{array}{c}4 \\
603 \\
607\end{array}$ & $\begin{array}{l}0.587 \\
2.266\end{array}$ & 0.259 & 0.904 \\
\hline $\begin{array}{l}\text { I love what I do and } \\
\text { want to do my best } \\
\text { in my work }\end{array}$ & $\begin{array}{l}\text { Between Groups } \\
\text { Within Groups } \\
\text { Total }\end{array}$ & $\begin{array}{l}22.538 \\
690.579 \\
713.117\end{array}$ & $\begin{array}{c}4 \\
603 \\
607\end{array}$ & $\begin{array}{l}5.634 \\
1.145\end{array}$ & 4.920 & 0.001 \\
\hline
\end{tabular}

Source: Author's conducted survey in 2017 of employees in telecommunication sector, $n=608$, Evaluation scale 1-7, where 1 - fully disagree; 7 - fully agree

The results indicate that only statement where the evaluations of respondents by age groups do not differ significantly with level of significance 0,001 is only for the statement, "I love what I do and want to do my best in my work".

Results on testing statistical hypotheses on differences in averages of evaluations on analysed statements of respondents by specialities groups are included in Table 5. 
Table 5

Main results on testing hypothesis on differences in evaluations of respondents by speciality with analysis of variance - ANOVA

\begin{tabular}{|c|c|c|c|c|c|c|}
\hline & & $\begin{array}{c}\text { Sum of } \\
\text { Squares }\end{array}$ & df & $\begin{array}{l}\text { Mean } \\
\text { Square }\end{array}$ & $\mathbf{F}$ & Sig. \\
\hline $\begin{array}{l}\text { I know what is ex- } \\
\text { pected from me in my } \\
\text { work }\end{array}$ & $\begin{array}{l}\text { Between Groups } \\
\text { Within Groups } \\
\text { Total }\end{array}$ & $\begin{array}{c}21.862 \\
526.860 \\
548.722\end{array}$ & $\begin{array}{c}6 \\
601 \\
607\end{array}$ & $\begin{array}{c}3.644 \\
.877\end{array}$ & 4.156 & 0.000 \\
\hline $\begin{array}{l}\text { My opinion and ideas } \\
\text { are important for my } \\
\text { company }\end{array}$ & $\begin{array}{l}\text { Between Groups } \\
\text { Within Groups } \\
\text { Total }\end{array}$ & $\begin{array}{c}27.468 \\
1006.202 \\
1033.669\end{array}$ & $\begin{array}{c}6 \\
601 \\
607\end{array}$ & $\begin{array}{l}4.578 \\
1.674\end{array}$ & 2.734 & 0.013 \\
\hline $\begin{array}{l}\text { From management I } \\
\text { receive evaluation on } \\
\text { my done job }\end{array}$ & $\begin{array}{l}\text { Between Groups } \\
\text { Within Groups } \\
\text { Total } \\
\end{array}$ & $\begin{array}{c}110.909 \\
1277.170 \\
1388.079 \\
\end{array}$ & $\begin{array}{c}6 \\
601 \\
607 \\
\end{array}$ & $\begin{array}{c}18.485 \\
2.125\end{array}$ & 8.698 & 0.000 \\
\hline $\begin{array}{l}\text { I feel care on my pro- } \\
\text { fessional development } \\
\text { from the management }\end{array}$ & $\begin{array}{l}\text { Between Groups } \\
\text { Within Groups } \\
\text { Total }\end{array}$ & $\begin{array}{c}35.309 \\
1124.716 \\
1160.025 \\
\end{array}$ & $\begin{array}{c}6 \\
601 \\
607 \\
\end{array}$ & $\begin{array}{l}5.885 \\
1.871\end{array}$ & 3.145 & 0.005 \\
\hline $\begin{array}{l}\text { I see possibilities } \\
\text { for my professional } \\
\text { development in this } \\
\text { company }\end{array}$ & $\begin{array}{l}\text { Between Groups } \\
\text { Within Groups } \\
\text { Total }\end{array}$ & $\begin{array}{c}36.656 \\
1359.843 \\
1396.498\end{array}$ & $\begin{array}{c}6 \\
601 \\
607\end{array}$ & $\begin{array}{l}6.109 \\
2.263\end{array}$ & 2.700 & 0.014 \\
\hline $\begin{array}{l}\text { I always receive } \\
\text { recognition from my } \\
\text { management for well- } \\
\text { done job }\end{array}$ & $\begin{array}{l}\text { Between Groups } \\
\text { Within Groups } \\
\text { Total }\end{array}$ & $\begin{array}{c}36.899 \\
1331.902 \\
1368.801 \\
\end{array}$ & $\begin{array}{c}6 \\
601 \\
607 \\
\end{array}$ & $\begin{array}{l}6.150 \\
2.216\end{array}$ & 2.775 & 0.011 \\
\hline $\begin{array}{l}\text { I love what I do and } \\
\text { want to do my best in } \\
\text { my work }\end{array}$ & $\begin{array}{l}\text { Between Groups } \\
\text { Within Groups } \\
\text { Total }\end{array}$ & $\begin{array}{c}16.535 \\
696.581 \\
713.117\end{array}$ & $\begin{array}{c}6 \\
601 \\
607\end{array}$ & $\begin{array}{l}2.756 \\
1.159\end{array}$ & 2.378 & 0.028 \\
\hline
\end{tabular}

Source: Author's conducted survey in 2017 of employees in telecommunication sector, $n=608$, Evaluation scale 1-7, where 1 - fully disagree; 7 -fully agree

The results of analysis of survey data indicate that the statements where the averages of evaluations by respondents by specialities groups do not differ significantly with level of significance 0.000 re for the statements "I know what is expected from me in my work" and "From management I receive evaluation on my done job”. Averages of evaluations by respondents also for other statements do not differ statistically significant with high probability (where the lowest probability is 0.986 ).

Results on testing statistical hypotheses on differences in averages of evaluations on analysed statements of respondents by work experience groups are included in Table 6. 
Table 6

Main results on testing hypothesis on differences in evaluations of respondents by work experience with analysis of variance - ANOVA

\begin{tabular}{|c|c|c|c|c|c|c|}
\hline & & $\begin{array}{c}\text { Sum of } \\
\text { Squares }\end{array}$ & df & $\begin{array}{l}\text { Mean } \\
\text { Square }\end{array}$ & $\mathbf{F}$ & Sig. \\
\hline \multirow{3}{*}{$\begin{array}{l}\text { I know what is } \\
\text { expected from me } \\
\text { in my work }\end{array}$} & Between Groups & 6.206 & 5 & \multirow{3}{*}{$\begin{array}{c}1.241 \\
.901\end{array}$} & \multirow[t]{3}{*}{1.377} & \multirow[t]{3}{*}{0.231} \\
\hline & Within Groups & 542.516 & 602 & & & \\
\hline & Total & 548.722 & 607 & & & \\
\hline \multirow{3}{*}{$\begin{array}{l}\text { My opinion and } \\
\text { ideas are important } \\
\text { for my company }\end{array}$} & Between Groups & 17.731 & 5 & 3.546 & \multirow[t]{3}{*}{2.101} & \multirow[t]{3}{*}{0.064} \\
\hline & Within Groups & 1015.939 & 602 & 1.688 & & \\
\hline & Total & 1033.669 & 607 & & & \\
\hline \multirow{3}{*}{$\begin{array}{l}\text { From management } \\
\text { I receive evaluation } \\
\text { on my done job }\end{array}$} & Between Groups & 9.695 & 5 & 1.939 & \multirow[t]{3}{*}{.847} & \multirow[t]{3}{*}{0.517} \\
\hline & Within Groups & 1378.384 & 602 & 2.290 & & \\
\hline & Total & 1388.079 & 607 & & & \\
\hline \multirow{3}{*}{$\begin{array}{l}\text { I feel care on my } \\
\text { professional devel- } \\
\text { opment from the } \\
\text { management }\end{array}$} & Between Groups & 14.180 & 5 & 2.836 & \multirow[t]{3}{*}{1.490} & \multirow[t]{3}{*}{0.191} \\
\hline & Within Groups & 1145.844 & 602 & 1.903 & & \\
\hline & Total & 1160.025 & 607 & & & \\
\hline \multirow{3}{*}{$\begin{array}{l}\text { I see possibilities } \\
\text { for my professional } \\
\text { development in } \\
\text { this company }\end{array}$} & Between Groups & 16.031 & 5 & 3.206 & \multirow[t]{3}{*}{1.398} & \multirow[t]{3}{*}{0.223} \\
\hline & Within Groups & 1380.467 & 602 & 2.293 & & \\
\hline & Total & 1396.498 & 607 & & & \\
\hline \multirow{3}{*}{$\begin{array}{l}\text { I always receive } \\
\text { recognition from } \\
\text { my management } \\
\text { for well-done job }\end{array}$} & Between Groups & 7.418 & 5 & 1.484 & \multirow[t]{3}{*}{0.656} & \multirow[t]{3}{*}{0.657} \\
\hline & Within Groups & 1361.383 & 602 & 2.261 & & \\
\hline & Total & 1368.801 & 607 & & & \\
\hline \multirow{3}{*}{$\begin{array}{l}\text { I love what I do } \\
\text { and want to do my } \\
\text { best in my work }\end{array}$} & Between Groups & 26.440 & 5 & 5.288 & \multirow[t]{3}{*}{4.636} & \multirow[t]{3}{*}{0.000} \\
\hline & Within Groups & 686.677 & 602 & 1.141 & & \\
\hline & Total & 713.117 & 607 & & & \\
\hline
\end{tabular}

Source: Author's conducted survey in 2017 of employees in telecommunication sector, $n=608$, Evaluation scale 1-7, where 1 - fully disagree; 7 - fully agree

The results of analysis of survey data indicate that the only statement where the averages of evaluations by respondents by work experience groups do not differ significantly with level of significance 0,000 are for the statement "I love what I do and want to do my best in my work". For other analysed statements, averages of evaluations by respondents do differ statistically significant with rather high probabilities. The biggest differences in average evaluations by respondents by work experience groups are for the statement, "I always receive recognition from my management for well-done job”.

Results on testing statistical hypotheses on differences in averages of evaluations on analysed statements of respondents by length of work in the company groups are included in Table 7. 
Table 7

Main results on testing hypothesis on differences in evaluation of respondents by length of work in the company with analysis of variance - ANOVA

\begin{tabular}{|c|c|c|c|c|c|c|}
\hline & & $\begin{array}{l}\text { Sum of } \\
\text { Squares }\end{array}$ & df & $\begin{array}{c}\text { Mean } \\
\text { Square }\end{array}$ & $\mathbf{F}$ & Sig. \\
\hline \multirow{3}{*}{$\begin{array}{l}\text { I know what is } \\
\text { expected from me in } \\
\text { my work }\end{array}$} & Between Groups & 4.354 & 5 & 0.871 & \multirow[t]{3}{*}{0.963} & \multirow[t]{3}{*}{0.440} \\
\hline & Within Groups & 544.368 & 602 & 0.904 & & \\
\hline & Total & 548.722 & 607 & & & \\
\hline \multirow{3}{*}{$\begin{array}{l}\text { My opinion and } \\
\text { ideas are important } \\
\text { for my company }\end{array}$} & Between Groups & 17.271 & 5 & 3.454 & \multirow[t]{3}{*}{2.046} & \multirow[t]{3}{*}{0.071} \\
\hline & Within Groups & 1016.398 & 602 & 1.688 & & \\
\hline & Total & 1033.669 & 607 & & & \\
\hline \multirow{3}{*}{$\begin{array}{l}\text { From management } \\
\text { I receive evaluation } \\
\text { on my done job }\end{array}$} & Between Groups & 9.419 & 5 & 1.884 & \multirow[t]{3}{*}{0.823} & \multirow[t]{3}{*}{0.534} \\
\hline & Within Groups & 1378.660 & 602 & 2.290 & & \\
\hline & Total & 1388.079 & 607 & & & \\
\hline \multirow{3}{*}{$\begin{array}{l}\text { I feel care on my } \\
\text { professional devel- } \\
\text { opment from the } \\
\text { management }\end{array}$} & Between Groups & 17.621 & 5 & 3.524 & \multirow[t]{3}{*}{1.857} & \multirow[t]{3}{*}{0.100} \\
\hline & Within Groups & 1142.404 & 602 & 1.898 & & \\
\hline & Total & 1160.025 & 607 & & & \\
\hline \multirow{3}{*}{$\begin{array}{l}\text { I see possibilities } \\
\text { for my professional } \\
\text { development in this } \\
\text { company }\end{array}$} & Between Groups & 49.916 & 5 & 9.983 & \multirow[t]{3}{*}{4.463} & \multirow[t]{3}{*}{0.001} \\
\hline & Within Groups & 1346.582 & 602 & 2.237 & & \\
\hline & Total & 1396.498 & 607 & & & \\
\hline \multirow{3}{*}{$\begin{array}{l}\text { I always receive } \\
\text { recognition from } \\
\text { my management for } \\
\text { well-done job }\end{array}$} & Between Groups & 7.040 & 5 & 1.408 & \multirow[t]{3}{*}{0.622} & \multirow[t]{3}{*}{0.683} \\
\hline & Within Groups & 1361.761 & 602 & 2.262 & & \\
\hline & Total & 1368.801 & 607 & & & \\
\hline \multirow{3}{*}{$\begin{array}{l}\text { I love what I do and } \\
\text { want to do my best } \\
\text { in my work }\end{array}$} & Between Groups & 10.807 & 5 & 2.161 & \multirow[t]{3}{*}{1.853} & \multirow[t]{3}{*}{0.101} \\
\hline & Within Groups & 702.309 & 602 & 1.167 & & \\
\hline & Total & 713.117 & 607 & & & \\
\hline
\end{tabular}

Source: Author's conducted survey in 2017 of employees in telecommunication sector, $n=608$, Evaluation scale 1-7, where 1 - fully disagree; 7 - fully agree

The results of analysis of survey data indicate that the only statement where the averages of evaluations by respondents by work experience groups do not differ significantly with level of significance 0.001 are for the statement "I see possibilities for my professional development in this company" and do not differ significantly with level of significance 0.100 are for the statement "I feel care on my professional development from the management". For other analysed statements, averages of evaluations by respondents do differ statistically significant with rather high probabilities. The biggest differences in average evaluations by respondents by length of work in the company groups are for the statement, "I always receive recognition from my management for well-done job". 
Results on testing statistical hypotheses on differences in averages of evaluations on analysed statements of respondents by education level groups are included in Table 8.

Table 8

Main results on testing hypothesis on differences in evaluations of respondent education level groups with analysis of variance - ANOVA

\begin{tabular}{|c|c|c|c|c|c|c|}
\hline & & $\begin{array}{l}\text { Sum of } \\
\text { Squares }\end{array}$ & df & $\begin{array}{c}\text { Mean } \\
\text { Square }\end{array}$ & $\mathbf{F}$ & Sig. \\
\hline $\begin{array}{l}\text { I know what is } \\
\text { expected from me in } \\
\text { my work }\end{array}$ & $\begin{array}{l}\text { Between Groups } \\
\text { Within Groups } \\
\text { Total } \\
\end{array}$ & $\begin{array}{l}4.432 \\
544.290 \\
548.722 \\
\end{array}$ & $\begin{array}{l}1 \\
606 \\
607 \\
\end{array}$ & $\begin{array}{l}4.432 \\
0.898\end{array}$ & 4.935 & 0.027 \\
\hline $\begin{array}{l}\text { My opinion and } \\
\text { ideas are important } \\
\text { for my company }\end{array}$ & $\begin{array}{l}\text { Between Groups } \\
\text { Within Groups } \\
\text { Total }\end{array}$ & $\begin{array}{l}3.148 \\
1030.521 \\
1033.669\end{array}$ & $\begin{array}{l}1 \\
606 \\
607\end{array}$ & $\begin{array}{l}3.148 \\
1.701\end{array}$ & 1.851 & 0.174 \\
\hline $\begin{array}{l}\text { From management } \\
\text { I receive evaluation } \\
\text { on my done job }\end{array}$ & $\begin{array}{l}\text { Between Groups } \\
\text { Within Groups } \\
\text { Total }\end{array}$ & $\begin{array}{l}25.797 \\
1362.282 \\
1388.079\end{array}$ & $\begin{array}{l}1 \\
606 \\
607\end{array}$ & $\begin{array}{l}25.797 \\
2.248\end{array}$ & 11.475 & 0.001 \\
\hline $\begin{array}{l}\text { I feel care on my } \\
\text { professional devel- } \\
\text { opment from the } \\
\text { management }\end{array}$ & $\begin{array}{l}\text { Between Groups } \\
\text { Within Groups } \\
\text { Total }\end{array}$ & $\begin{array}{l}2.704 \\
1157.321 \\
1160.025\end{array}$ & $\begin{array}{l}1 \\
606 \\
607\end{array}$ & $\begin{array}{l}2.704 \\
1.910\end{array}$ & 1.416 & 0.235 \\
\hline $\begin{array}{l}\text { I see possibilities } \\
\text { for my professional } \\
\text { development in this } \\
\text { company }\end{array}$ & $\begin{array}{l}\text { Between Groups } \\
\text { Within Groups } \\
\text { Total }\end{array}$ & $\begin{array}{l}1.829 \\
1394.669 \\
1396.498 \\
\end{array}$ & $\begin{array}{l}1 \\
606 \\
607\end{array}$ & $\begin{array}{l}1.829 \\
2.301\end{array}$ & 0.795 & 0.373 \\
\hline $\begin{array}{l}\text { I always receive } \\
\text { recognition from } \\
\text { my management for } \\
\text { well-done job }\end{array}$ & $\begin{array}{l}\text { Between Groups } \\
\text { Within Groups } \\
\text { Total }\end{array}$ & $\begin{array}{l}2.227 \\
1366.574 \\
1368.801\end{array}$ & $\begin{array}{l}1 \\
606 \\
607\end{array}$ & $\begin{array}{l}2.227 \\
2.255\end{array}$ & 0.988 & 0.321 \\
\hline $\begin{array}{l}\text { I love what I do and } \\
\text { want to do my best } \\
\text { in my work }\end{array}$ & $\begin{array}{l}\text { Between Groups } \\
\text { Within Groups } \\
\text { Total }\end{array}$ & $\begin{array}{l}3.730 \\
709.387 \\
713.117\end{array}$ & $\begin{array}{l}1 \\
606 \\
607\end{array}$ & $\begin{array}{l}3.730 \\
1.171\end{array}$ & 3.186 & 0.075 \\
\hline
\end{tabular}

Source: Author's conducted survey in 2017 of employees in telecommunication sector, $n=608$, Evaluation scale 1-7, where 1 - fully disagree; 7 - fully agree

The results of analysis of survey data indicate that the only statement where the averages of evaluations by respondents by work experience groups do not differ significantly with level of significance 0.001 are for the statement "From management I receive evaluation on my done job" and do not differ significantly with level of significance 0.027 are for the statement "I know what is expected from me in my work". The biggest differences in average evaluations by respondents by level of education groups are for the statement, "I see possibilities for my professional development in this company". 
The study confirmed the hypothesis that engagement clearly explains the motivating psychological state and behaviour of employee. As engagement is associated with a positive emotional experience, which is often regarded as a fulfilling satisfaction, it is thereby giving an intrinsically motivating value. Results of analysis of regression with engagement as dependent variable are included in Table 9. The engagement in the regression model is explained by almost $65 \%$ in the variation of the organisational citizenship behaviour that characterises motivation and organisational support staff behaviour $\left(R=0.805 ; R^{2}=0.648\right.$; Adj $R^{2}=0.648$; Table 9). As results indicate by improving respondents' assessment of the engagement per unit, the behavioural activity assessment is expected to increase on average by 0.8 units.

Table 9

Results of Analysis of Regression with Engagement as Dependent variable

\begin{tabular}{|l|c|c|}
\hline \multicolumn{1}{|c|}{ Dependent variable } & \multicolumn{2}{|c|}{ Independent Variable in Regression Equation } \\
\hline & \multicolumn{2}{|c|}{ Plans to Stay within the Organisation } \\
\hline Engagement & Adj $R^{2}$ & 0.191 \\
\hline & $\beta$ & 0.438 \\
\hline & Management evaluation of Employee's performance \\
\hline Engagement & Adj $R^{2}$ & 0.071 \\
\hline & $\beta$ & 0.269 \\
\hline & Motivating and Supporting Behaviour (OCB) \\
\hline Engagement & Adj $R^{2}$ & 0.648 \\
\hline & $\beta$ & 0.805 \\
\hline & Tolerance T & 1 \\
\hline
\end{tabular}

$p<0.001, \beta$ - Standardised coefficients of regression, Adj R2 - Coefficient of Determination Adjusted Source: Author's conducted survey in 2017 of employees in telecommunication sector, $n=608$, Evaluation scale 1-7, where 1 - fully disagree; 7 - fully agree

The organisational citizenship behaviour in the author's model is characterised by six mutually correlated variables - commitment of organization, organizational supportive behaviour, and extra-role behavioural variables (Table 10). Thus, the management of the organisation, by stimulating one of them (for example, inspiring ones to work with full rewards), will promote as well a non-direct extra-role factors such as recommending a company as a good job or a company volunteering to enhance its reputation. The study confirmed the hypothesis that the engagement affects the employee's intent not to stay within the organisation, but according to this study, the author acknowledges that involvement is a rather weak predictor of intent $\left(\mathrm{adj} R^{2}=0.191\right)$. However, the regression coefficient of the intent variable is sufficiently high $(\beta=0.438)$. 
Results on Factor analysis on Organizational Citizenship Behaviour

\begin{tabular}{|c|c|c|}
\hline & Component Matrix & $\begin{array}{c}\text { Organizational } \\
\text { citizenship behaviour }\end{array}$ \\
\hline 1 & This company inspires me to use my skills to their fullest potential & 0.852 \\
\hline 2 & I recommend this company to others without hesitation & 0.817 \\
\hline 3 & I feel motivated to do more than is required of me. & 0.765 \\
\hline 4 & $\begin{array}{l}\text { I truly care about this company, its future and the goals we are } \\
\text { working towards }\end{array}$ & 0.747 \\
\hline 5 & I see opportunities for professional advancement in this company & 0.688 \\
\hline \multirow[t]{8}{*}{6} & I tell others about the great things in this company & 0.480 \\
\hline & Extraction Method: Principal Component Analysis & a 1 components extracted \\
\hline & KMO and Bartlett's Test & \\
\hline & Kaiser-Meyer-Olkin Measure of Sampling Adequacy & 0.842 \\
\hline & Bartlett's Test of Sphericity & 1298.918 \\
\hline & $\mathrm{df}$ & 15 \\
\hline & Sig. & 0.000 \\
\hline & Cronbach's Alpha Based on Standardized Items & 0.822 \\
\hline
\end{tabular}

Source: Author's conducted survey in 2017 of employees in telecommunication sector, $n=608$, Evaluation scale 1-7, where 1 - fully disagree; 7 - fully agree

As would be expected, engagement is related significantly and in meaningful ways to job related attitudes, behaviour and intentions on the job. These results testify that engagement is related to, but can be discriminated from behavioural intentions and actual behaviour that reflects an employee's commitment to the organisation and its goals.

\section{CONCLUSIONS}

The study revealed that levels of engagement are positively related to indicators of employee loyalty, commitment and turnover. The study confirms the hypothesis that the high levels of engagement can lead over time to more organisational commitment, more personal initiative, better role performance and less frequent leaving the company. This means that engagement must be the subject of a management whose purpose is to focus on achieving or exceeding the organisation's results. As mentioned earlier, employee engagement is the most critical factor in the process of enhancing the business performance. Employees basically are the real representatives and brand bearers of any organisation. Engagement may be described as a two way process between employees and an organisation. Engagement must be a strategy to enhance the productivity and performance of an employee; it is also a process to ensure the commitment, 
motivation and contribution of an employee towards achieving the goals and values; needless to add, it also goes with enhancing their own wellbeing.

\section{REFERENCES}

Aithal, P. S., Kumar, P. M. (2015). Black Ocean Strategy - A Probe into a New type of Strategy used for Organizational Success. GE International Journal of Management Research, 3 (8), 45-65.

Albrecht, S. L., Bakker, A. B., Gruman, J. A., Macey, W. H., Saks, A. (2015). Employee engagement, human resource management practices and competitive advantage: An integrated approach. Journal of Organizational Effectiveness: People and Performance, 2 (1), 7-35.

Bakker, A. B., Demerouti, E. (2008). Towards a model of work engagement. Career Development International, 13 (3), 209-223.

Bakker, A. B., Van Emmerik, H., Van Riet, P. (2008). How job demands, resources, and burnout predict objective performance: A constructive replication. Anxiety, Stress \& Coping, 21 (3), 309-324.

Bal, P. M., Jansen, P. G. W., Velde, E. G. van der, Lange, A. H. de, Rousseau, D. M. (2010). The role of future time perspective in psychological contracts. A study among older workers. Journal of Vocational Behavior, 76, 474-486.

Boselie, P., DerWiele, T. (2002). Employee perceptions of HRM and TQM and the effects on satisfaction and intention to leave. Management Service Quality, 12 (3), $165-172$.

Cameron, K. S., Dutton, J. E., Quinn, R. E. (2003). Positive Organizational Scholarship: Foundations of New Discipline, Berrett-Koehler Publishers Inc., San Francisco, CA, 309-327.

Caza, A., Cameron, K. (2008). Positive Organizational Scholarship: What Does It Achieve? Handbook of Macro-Organizational Behavior. New York: Sage.

Cerasoli, C. P., Nicklin, J. M., Ford, M. T. (2014). Intrinsic motivation and extrinsic incentives jointly predict performance: a 40-year meta-analysis. Psychology Bulletin, 140 (4), 980-1008.

Cropanzano, R., Wright, T. A. (2001). When a "happy" worker is a "productive" worker: A review and further refinement of the happy-productive worker thesis. Consulting Psychology Journal: Practice and Research, 53, 182-199.

Foster, R. (2010). Resistance, Justice and Commitment to Change. Human Resource Development Quarterly, 21 (1), 3-39.

Frank, F. D., Finnegan, R. P., Taylor, C. R. (2004). The race for talent: retaining and engaging workers in the $21^{\text {st }}$ century'. Human Resource Planning, 27 (3), 12-25.

Gordon, H. J., Demerouti, E., Bipp, T., Le Blanc, P. M. (2015). The job demands and resources decision making (JD-RDM) model. European Journal of Work \& Organizational Psychology, 24 (1), 44-58.

Harter, J. K., Schmidt, F. L., Agrawal, S., Plowman, S. K. (2013). The relationship between engagement at work and organizational outcomes: 2012 Q12 meta analysis. Washington, DC: Gallup.

Kahn, W. (1990). Psychological conditions of personal engagement and disengagement at work. Academy of Management Journal, 33 (4). 692-724.

Kaliannan, M., Adjovu, S. N. (2015). Effective employee engagement and organizational success: a case study. Social and Behavioral Sciences, 172, 161-168. 
Katou, A. A., Budhwar, P. (2015). Human resource management and organisational productivity: A systems approach based empirical analysis. Journal of Organizational Effectiveness: People and Performance, 2 (3), 244-266.

Kersule, L. (2011). Personnel Motivation Problems in a Big Company in World Economic Crisis Situation. International Conference on Current Issues in Management of Business and Society Development Proceedings. University of Latvia, Riga, Latvia, May 7-9, 2009, 162-166.

Koutroumpis, P. (2009). The economic impact of broadband on growth: a simultaneous approach. Telecommunications Policy, 33, 471-485.

Kumar, V., Pansari, A. (2014). The Construct, Measurement, and Impact of Employee Engagement: a Marketing Perspective. Customer Needs and Solutions, 1, 52-67.

Lodahl, T. M., Kejner, M. (1965). The Definition and Measurement of Job Involvement. Journal of Applied Psychology, 49 (1), 24-33.

Macey, W., Schneider, B. (2008). The Meaning of Employee Engagement, Industrial and Organizational Psychology, 1, 3-30.

Meyer, J. P., Allen, N. J. (1997). Commitment in the Workplace: Theory, Research and Application. Sage Publications.

Newman, D. A., Harrison, D. A. (2008), "Been there, bottled that: are state and behavioral work engagement new and useful construct 'wines'?". Industrial and Organizational Psychology, 1, 31-35.

Peale, N. V. (1956). The Power of Positive Thinking, Prentice-Hall, Englewood Cliffs, NJ.

Peterson, S., Luthans, F., Avolio, B., Walumbwa, F., Zhang, Z. (2011). Psychological capital and employee performance: A latent growth modelling approach. Personnel Psychology, 64 (2), 427-450.

Rana, N., Chhabra, N. L. (2011). Employee Engagement: A primer for strategic human resource management. Asian Journal of Research in Business, Economics and Management, 1 (2), 16-27.

Rayton, B. A., Yalabik, Z. Y. (2014). Work engagement, psychological contract breach and job satisfaction. The International Journal of Human Resource Management, 25 (17), 2382-2400.

Saks, A. M. (2006). Antecedents and consequences of employee engagement. Journal of Managerial Psychology, 21 (7), 600-619.

Schaufeli, W. B. (2013). What is engagement? In Truss, C., Alfes, K., Delbridge, R., Shantz, A., Soane, E. (Eds.). Employee Engagement in Theory and Practice. London: Routledge, pp. 14.

Schaufeli, W. B., Salanova, M., Gonzalez-Roma, V., Bakker, A. B. (2002). The measurement of engagement and burnout: A two sample confirmatory factor analytic approach. Journal of Happiness Studies, 3 (1), 71-92.

Sumanth, D. (1998). Total productivity management: A Systemic and Quantitative Approach to Compete in Quality, Price and Time. USA: CRC Press LLC.

Swart, J. (2007). Whose Human Capital? The Challenge of Value Capture When Capital Is Embedded. Journal of Management Studies, 44 (4), 488-505.

Tarafdar, M., Tu, Q. Ragu-Nathan, B. S., Ragu-Nathan, T. S. (2007). The impact of technostress on role stress and productivity. Journal of Management Information Systems, 24, 301-328.

Vroom, V. H. (1964). Work and Motivation. New York: Wiley.

Xanthopoulou, D., Bakker, A. B., Demerouti, E., Schaufeli, W. B. (2009). Work engagement and financial returns: a diary study on the role of job and personal resources. Journal of Occupational and Organizational Psychology, 82 (1), 183-200. 
Yalabik, Z. Y., Popaitoon, P., Chowne, J. A., Rayton, B. A. (2013). Work Engagement as a Mediator between Employee Attitudes and Outcomes. International Journal of Human Resource Management, 24, 2799-2823.

Zigarmi, D., Nimon, K., Houson, D., Witt, D., Diehl, J. (2009). Beyond engagement: toward a framework and operational definition for employee work passion. Human Resource Development Review, 8 (3), 300-326.

Woerkom, M. van, Oerlemans, M. Bakker, A. B. (2016). Strengths use and work engagement: a weekly diary study. European Journal of Work and Organizations Psychology, 25 (3), 384-397. 


\title{
DETERMINANTS OF TOTAL FACTOR PRODUCTIVITY IN EIGHT EUROPEAN COUNTRIES
}

\author{
LAIMDOTA KOMARE
}

\begin{abstract}
Since the study of Solow (1957) that recognised that growth in developed economies was not due to accumulation of production factors, but a residual total factor productivity (TFP), TFP and its determinants became important topic of research. TFP growth has become the most important factor of growth in developed and developing countries. The aim of this research is to find TFP determinants in eight European countries through implementation of empirical analysis and to recognise the more effective ones. Understanding the TFP growth determinants is important to build individual growth model. The article analyses the determinants of TFP growth in eight European countries: Czech Republic, Estonia, Hungary, Latvia, Lithuania, Poland, Slovak Republic and Slovenia during 1997-2016. The theory indicates there are such determinants of TFP growth as trade openness, R\&D, foreign direct investment, education, institutional framework. The study takes these determinants into account and bases the analysis on panel data and regressions. The results show a positive, significant influence of openness of trade and the share of labour force with tertiary education on TFP growth. Unfortunately, such variables as FDI share and $R \& D$ expenses that were expected to have positive influence do not appear as significant determinants of TFP growth.
\end{abstract}

Key words: total factor productivity, growth model

JEL code: E230

\section{INTRODUCTION}

Between 1995 and 2012, the Czech Republic, Estonia, Hungary, Latvia, Lithuania, Poland, Slovak Republic and Slovenia have followed an extensive and investment-oriented growth model. During this period the region countries became the most dynamically developing in the world (Becker et al., 2010). Despite brilliant economic growth and development, all the countries were hit hard by the global crisis. As the result, they experienced a large decline of capital stock, low investment rate, low productivity growth and faced slow recovery (Conference Board, 2015). Circumstances define that the countries are struggling to attract capital investments and need to find a new sustainable and long-term source of growth. 
Recent economic literature assumes that total factor productivity (TFP) growth is considered to be a sustainable source of long-term economic growth. TFP measurement history started with Solow (1957) when the author introduced the additional production factor. The reason was that the other two factors - labour and capital, were not able to explain output produced, and the new component of the equation was explained as measure of efficiency of factors used in production. In a Cobb-Douglas production function (1) TFP is captured by the variable, and it measures technology contribution to output (.) in country $c$ at time $t$.

$$
Y_{c t}=A \cdot K_{c t}^{\beta k} \cdot L_{c t}^{\beta l}
$$

Following early attempts Solow (1957), growth accounting with TFP growth started to really develop with the work of various scholars, including Kendrick (1961), Denison (1962) and Jorgenson and Griliches (1967). The importance of TFP is reflected in overall output growth that is determined by labour productivity, number of workers and working hours involved in production. Labour productivity reflects the increase in the contribution of capital, increase in the contribution of human capital and the increase in overall efficiency of production - total factor productivity (see Figure 1). However, TFP growth measure is not influenced by other production input factors, and it exists by itself. Mainly the contribution of productivity of the factor endowments as labour and capital drives TFP growth that may occur as a spillover result from use of better technology and equipment or improved management and human capital input. Both production factors, physical and human capital, are important and are influenced by free trade that will be discussed in the next section.

Moreover, TFP relates to both technology improvements and human capital improvements that lead to better technology use. TFP refers to methods employed by labour and capital that lead to more efficient and faster production, for example, productivity input brought by $\mathrm{R} \& \mathrm{D}$, education, government efficiency, etc. (Grossman and Helpman, 1991; Borensztein et al., 1998; Barro, 2001).

The theoretical literature and empirical studies offer a number of possible TFP growth determinants, such as $\mathrm{R} \& \mathrm{D}$, trade openness, education, institutional framework. Empirical studies propose that trade openness and increasing FDI result in $\mathrm{R} \& \mathrm{D}$ - through not only international cooperation and spillovers, as well through rising competition in internal market. Grossman and Helpman (1991) argue that foreign competition brought by import forces domestic firms to innovate. Innovation-based growth model discussed by Grossman and Helpman (1991) suggests that R\&D leads to innovations, and that results in increase of output. FDI has been admitted as an important source of productivity due to its effect on spillovers between domestic and foreign firms. Borensztein et al. (1998) considers that FDI influences economic growth through improvements of technology and productivity. Barro (2001) states that higher human capital leads to TFP growth. The influence discussed in Barro (2001) is due to high-skilled 


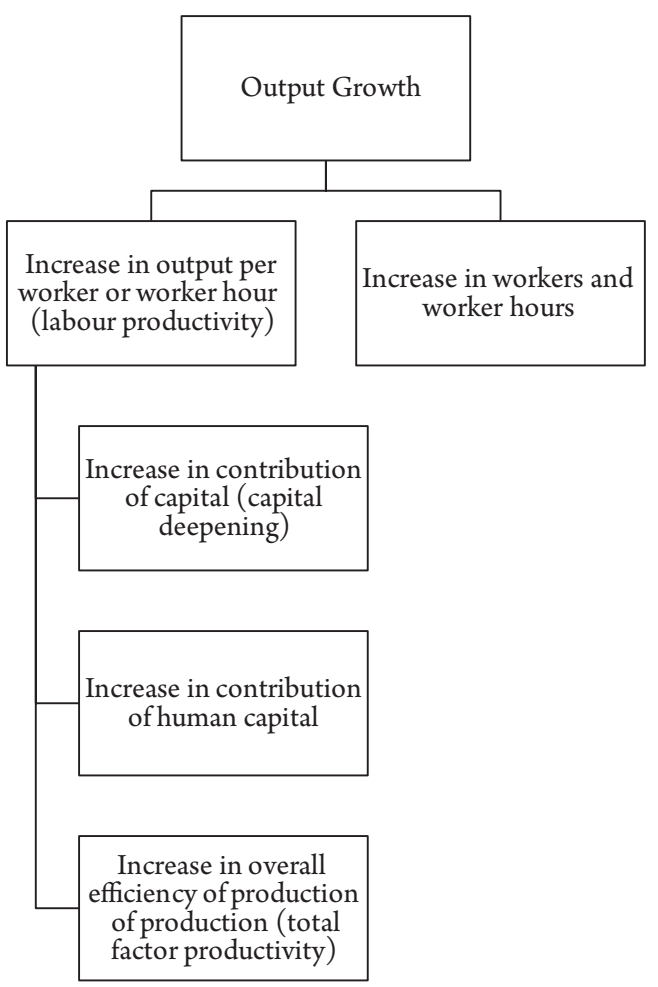

Source: The Conference Board, 2015

Fig. 1. Defining Output Growth

and well-educated labour abilities to absorb and apply superior technologies. A country with better labour quality is more able to benefit from openness of trade and FDI. Moreover, studies also focused on political and institutional framework as possible productivity drivers. For example, Becker et al. $(2010,2012)$ found a positive impact of the EU Structural Funds on output growth. The majority of Eastern European countries used the opportunity of the EU funds to catch up to developed union members. Efficient and productive institutions have a positive impact on aggregate productivity through boosting investments. There are many specific influence channels that are captured under the institutional framework, such as political situation, regulation and implementation systems that need to be addressed as possible TFP determinants.

Figure 2 shows TFP growth among eight EU countries from 1997 until 2016. TFP growth has been various during the period, and there is not any countryoutlier that has been showing only positive or only negative TFP growth during this period. Almost all countries experienced negative TFP growth in 2008 and 2009 that is a result of global crisis in 2008. TFP growth in Poland is captured with huge fluctuations. The lowest TFP growth among all countries refers to Lithuania. It was $-12.43 \%$ in 2010. The highest TFP growth was in Estonia in 
$1998-9.77 \%$. The changes in TFP growth observed from the Figure 2 cannot be explained without insight into TFP growth determinants and their changes during the period due to the fact that TFP growth in different countries shows such variation without any common trends. TFP growth experienced fluctuations without any trend except crisis in 2009.
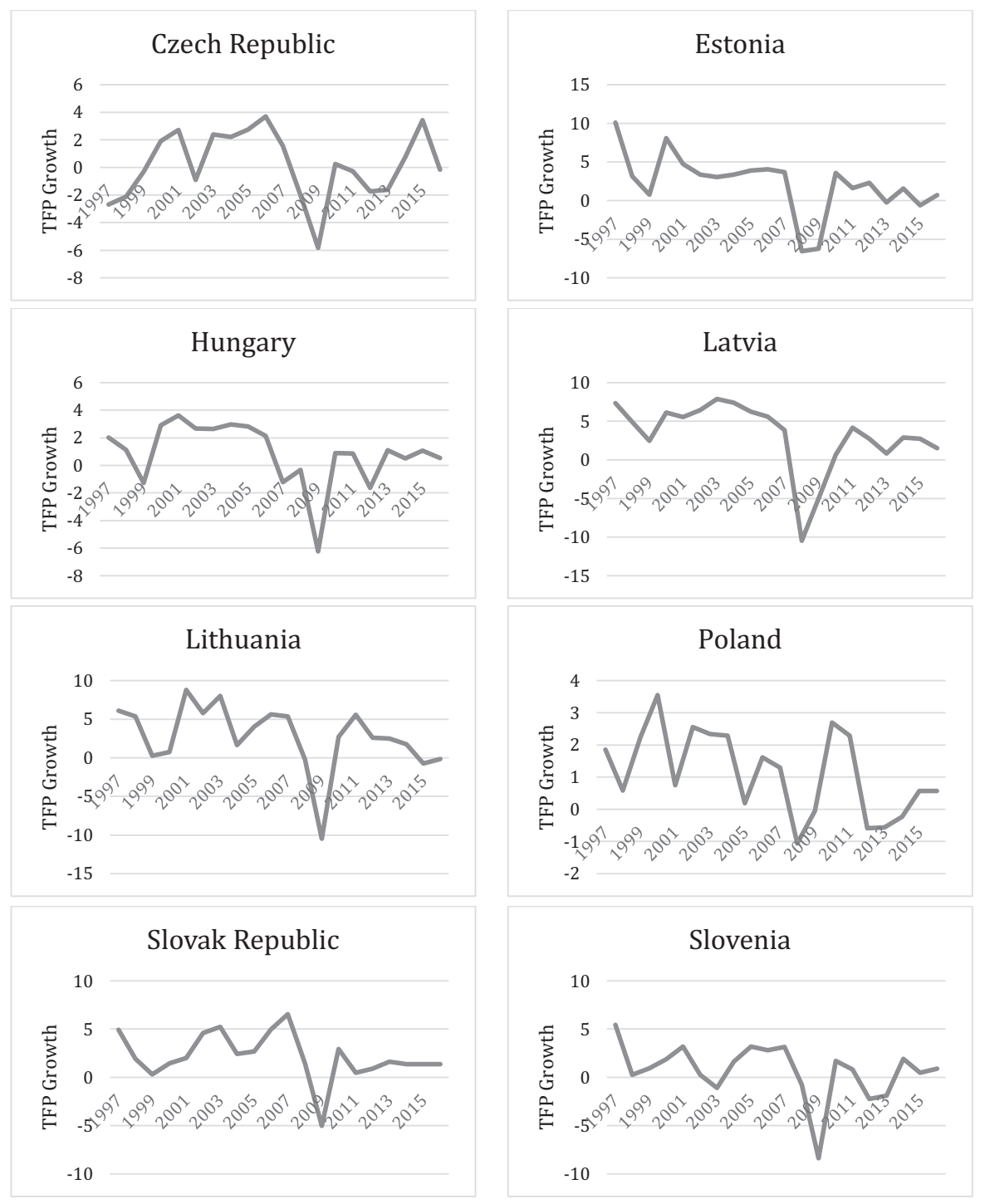

Source: Conference Board Total Economy Database

Fig. 2. TFP growth (\%) 
The main aim of the research is to investigate determinants of TFP in eight European countries - Czech Republic, Estonia, Hungary, Latvia, Lithuania, Poland, Slovak Republic, and Slovenia. The research question is - "Which TFP determinants do positively influence TFP growth in 8 European countries?" The observed time period is 1997-2016. As the determinants of TFP growth were chosen and checked were such variables as openness of trade, cover ratio, FDI share of GDP, labour force with tertiary education, government effectiveness, corruption control and R\&D expenses as share of GDP. The author found a positive, significant influence of openness of trade on TFP growth. The share of labour force with tertiary education also is positively associated with TFP growth. Such variables as FDI share and R\&D expenses that were expected to have positive influence do not appear as significant determinants of TFP growth.

Understanding the TFP growth determinants is important for future economic growth of the union, because the empirical results may not follow the theoretical framework.

\section{RESEARCH RESULTS AND DISCUSSION}

The regression model (2) used in the research consists of 13 independent variables that were selected from theoretical and empirical literature as TFP determinants or indicators that may affect TFP growth:

TFPGrowth $_{c t}=\beta_{0}+\beta_{1}$ Openness $_{c t}+\beta_{2}$ CoverRatio $_{c t}+$

$\beta_{3}$ FDIShare $_{c t}+\beta_{4}$ TertEduc $_{c t}+$

$\beta_{5}$ ManufShare $_{c t}+\beta_{6} R D_{c t}+\beta_{7}$ lnLabProdLevel $_{c t}+$

$\beta_{8}$ GovEffect $_{c t}+\beta_{9}$ CorrCntrl $_{c t}+\beta_{10}$ TFPpre $_{c t}+$

$\beta_{11}$ lnLabProdLevelPreYear ${ }_{c t-1}+$

$\beta_{12}$ DummyE $U_{c t}+\beta_{13}$ DummyCrisis $2008_{c t}+u_{c t}$

The model consists of such variables as trade openness (share of trade with respect to GDP), cover ratio (export divided by import), FDI share, share of labour with tertiary education, manufacturing share, $R \& D$ expenses with the respect to GDP, the World Bank index of government effectiveness, the World Bank corruption control index - the variables that may influence TFP growth, and control variables - labour productivity level of current and previous year, TFP growth of previous year, dummy of EU membership, dummy of crisis in 2008.

The data on the aggregate TFP growth and GDP growth is taken from Conference Board Total Economy Database. Data on import, export, foreign direct investment inflow and labour share with tertiary education is obtained from the World Bank World Development Indicators database. Data on government effectiveness and corruption control is obtained from the World Bank Worldwide Governance Indicators database. Data on labour productivity 
per person employed in 2014 \$ US is obtained from the Conference Board Total Economy Database. Data on R\&D expenses as a percentage of GDP is obtained from UNESCO database. Unfortunately, data on R\&D expenses is missing for Lithuania for time period from 1997 until 2004.

The Model 1 includes 12 independent variables. Model 2 includes 13 independent variables. As mentioned before, there are missing $\mathrm{R} \& \mathrm{D}$ expenses observations for Lithuania, therefore, they were not included in Model 1. The two models are conducted to fixed effects, and Driscoll and Kraay standard errors were applied to solve cross-sectional dependence. The models show highly significant and positive impact of trade openness on TFP growth. The labour share with tertiary education has a positive influence on TFP growth, but at the same time, it is poorly significant in the Model 1 . The introduced variable of R\&D expenses has a high coefficient value, but at the same time, it is insignificant and has the largest standard error. After introducing the variable other coefficients experience little changes. Tertiary education model doubles its value and becomes highly significant. Conversely, government effectiveness variable loses its significance. Such control variables as labour productivity level of current and previous year, TFP growth of previous year, and dummy of crisis in 2008 appear as significant. The estimate results of the models are represented in the Table 1.

Table 1

Estimate results (Models 1, 2)

\begin{tabular}{|c|c|c|}
\hline VARIABLES & $\begin{array}{l}\text { Model } 1 \\
\text { TFP Growth }\end{array}$ & $\begin{array}{l}\text { Model } 2 \\
\text { TFP Growth }\end{array}$ \\
\hline Openness & $6.724^{* * *}(1.601)$ & $5.672^{* * *}(1.529)$ \\
\hline CoverRatio & $1.307(1.163)$ & $1.164(1.175)$ \\
\hline FDIShare & $0.217(1.091)$ & $0.621(1.320)$ \\
\hline TertEduc & $4.998^{*}(2.558)$ & $9.286^{* * *}(1.504)$ \\
\hline GovEffect & $0.133^{* * *}(0.0400)$ & $0.0688(0.0430)$ \\
\hline CorrCntrl & $-0.0246(0.0399)$ & $0.0106(0.0451)$ \\
\hline lnLabProdLevel & $61.26^{* * *}(15.07)$ & $65.27^{* * *}(15.38)$ \\
\hline lnLabProdLevelPreYear & $-65.31^{* * *}(13.80)$ & $-69.60^{* * *}(13.93)$ \\
\hline TFPpre & $0.116^{*}(0.0627)$ & $0.116^{*}(0.0597)$ \\
\hline Manuf & $0.613^{* * *}(0.126)$ & $0.615^{* * *}(0.175)$ \\
\hline DummyEU & $-0.876(0.590)$ & $-0.763(0.695)$ \\
\hline DummyCrisis2008 & $-1.881^{* * *}(0.372)$ & $-1.643^{* * *}(0.350)$ \\
\hline $\mathrm{RD}$ & & $44.73(68.40)$ \\
\hline Constant & $12.28(30.19)$ & $17.24(29.73)$ \\
\hline R-sq & 0.76 & 0.77 \\
\hline $\begin{array}{l}\text { Standard errors in parentheses } \\
{ }^{* * *} \mathrm{p}<0.01,{ }^{* *} \mathrm{p}<0.05,{ }^{*} \mathrm{p}<0.1\end{array}$ & & \\
\hline
\end{tabular}

Source: author's calculations 
The Table 2 represents results of Model 3, Model 4, Model 5 and Model 6. The Model 3 captures determinants of TFP growth in Czech Republic, the Model 4 captures determinants of TFP growth in Estonia, the Model 5 captures determinants of TFP growth in Hungary, and the Model 6 captures determinants of TFP growth in Latvia. The Table 2 captures the features we saw in the Table 1. Significant determinants of TFP growth in all four countries is trade openness. FDI share is poorly significant in Estonia and Hungary, the later one shows FDI share as negatively related to TFP growth. Labour share with tertiary education is significant in Hungary and Latvia. R\&D is significant determinant of TFP growth in Estonia and Latvia, and is poorly significant in Czech Republic.

Estimate results (Models 3, 4, 5, 6)

Table 2

\begin{tabular}{|c|c|c|c|c|}
\hline VARIABLES & $\begin{array}{l}\text { Model } 3 \text { Czech } \\
\text { Republic } \\
\text { TFP Growth }\end{array}$ & $\begin{array}{l}\text { Model } 4 \text { Estonia } \\
\text { TFP Growth }\end{array}$ & $\begin{array}{l}\text { Model } 5 \text { Hungary } \\
\text { TFP Growth }\end{array}$ & $\begin{array}{l}\text { Model } 6 \text { Latvia } \\
\text { TFP Growth }\end{array}$ \\
\hline Openness & $9.471^{* * *}(1.324)$ & $7.492^{* * *}(1.995)$ & $2.015^{* * *}(1.368)$ & $6.611^{* * *}(3.138)$ \\
\hline CoverRatio & $3.926(7.521)$ & $3.874(8.802)$ & $0.057(3.656)$ & $-4.102(3.128)$ \\
\hline FDIShare & $18.901(17.292)$ & $4.638695^{*}(6.98794)$ & $-1.84766^{*}(7.017)$ & $7.331(3.733)$ \\
\hline TertEduc & $62.283(67.428)$ & $-1.856(15.883)$ & $3.881^{* * *}(109.043)$ & $4.727^{* *}(60.070)$ \\
\hline GovEffect & $0.380^{*}(0.218)$ & $-0.116(0.218)$ & $-0.328^{*}(0.736)$ & $0.462^{*}(0.233)$ \\
\hline CorrCntrl & $0.008(0.209)$ & $-0.547(0.277)$ & $-0.004(0.476)$ & $-0.269(0.169)$ \\
\hline lnLabProdLevel & $41.27^{* * *}(15.07)$ & $38.14^{* * *}(14.78)$ & $39.27^{* * *}(15.24)$ & $42.34^{* * *}(15.36)$ \\
\hline $\begin{array}{l}\text { lnLabProdLevel- } \\
\text { PreYear }\end{array}$ & $-45.40^{* * *}(12.47)$ & $-39.37^{* * *}(16.73)$ & $-38.28^{* * *}(12.90)$ & $-40.53^{* * *}(15.93)$ \\
\hline TFPpre & $0.024^{*}(0.097)$ & $0.056^{*}(0.129)$ & $0.095^{*}(0.062)$ & $0.074^{*}(0.054)$ \\
\hline Manuf & $0.589^{* * *}(0.128)$ & $0.725^{* * *}(0.174)$ & $0.590^{* *}(0.137)$ & $0.852^{* *}(0.195)$ \\
\hline DummyEU & $0.919(0.470)$ & $0.582(0.525)$ & $-0.734(0.590)$ & $-0.052(0.725)$ \\
\hline $\begin{array}{l}\text { Dummy } \\
\text { Crisis2008 }\end{array}$ & $-1.690^{* * *}(0.362)$ & $-1.723^{* * *}(0.363)$ & $-1.712^{* * *}(0.421)$ & $-1.943^{* * *}(0.402)$ \\
\hline $\mathrm{RD}$ & $0.284^{*}(0.001)$ & $2.53(3.470)^{* * *}$ & $14.83(25.187)$ & $1.14(2.032)^{* *}$ \\
\hline Constant & $-3.278(45.945)$ & $21.382(31.721)$ & $24.146(97.858)$ & $7.455(17.188)$ \\
\hline R-sq & 0.82 & 0.88 & 0.79 & 0.78 \\
\hline
\end{tabular}

Source: author's calculations

The Table 3 represents results of Model 7, Model 8, Model 9 and Model 10. The Model 7 captures determinants of TFP growth in Lithuania, the Model 8 captures determinants of TFP growth in Poland, the Model 9 captures determinants of TFP growth in Slovak Republic, and the Model 10 captures determinants of TFP growth in Slovenia. Trade openness shows positive and significant relation to TFP growth in all models. For Lithuania, trade openness 
is more favourable for TFP growth, because coefficient is times bigger than in the models of other countries. Government effectiveness is highly significant for TFP growth in Slovenia. Tertiary education is poorly significant in Model of Lithuania, Slovak Republic and Slovenia, and insignificant in the Model of Poland. Labour share with tertiary education is significant in Lithuania, Slovak Republic and Slovenia. R\&D is significant determinant of TFP growth in Slovak Republic. In the Model of Lithuania R\&D is not taken into account due to a lack of data.

Estimate results (Models 7, 8, 9, 10)

Table 3

\begin{tabular}{|l|c|c|c|c|}
\hline \multicolumn{1}{|c|}{ VARIABLES } & $\begin{array}{c}\text { Model 7 } \\
\text { Lithuania } \\
\text { TFP Growth }\end{array}$ & $\begin{array}{c}\text { Model 8 Poland } \\
\text { TFP Growth }\end{array}$ & $\begin{array}{c}\text { Model 9 Slovak } \\
\text { Republic } \\
\text { TFP Growth }\end{array}$ & $\begin{array}{c}\text { Model 10 } \\
\text { Slovenia } \\
\text { TFP Growth }\end{array}$ \\
\hline Openness & $6.871^{* * *}(3.138)$ & $1.214^{* * *}(8.175)$ & $2.914^{* * *}(2.662)$ & $1.724^{* * *}(1.601)$ \\
\hline CoverRatio & $1.762(3.007)$ & $-6.210(10.813)$ & $4.924(3.305)$ & $1.307(1.163)$ \\
\hline FDIShare & $3.731(2.128)$ & $3.159(21.304)$ & $0.916(4.565)$ & $0.217(1.091)$ \\
\hline TertEduc & $5.727^{* *}(10.070)$ & $24.621(26.30437)$ & $0.216(2.275)$ & $4.998^{* * *}(2.558)$ \\
\hline GovEffect & $0.450^{*}(0.212)$ & $0.461(0.127)$ & $0.120(0.057)$ & $0.133^{* * *}(0.0400)$ \\
\hline CorrCntrl & $-0.349(0.190)$ & $-0.525(0.028)$ & $-0.015(0.056)$ & $-0.0246(0.0399)$ \\
\hline lnLabProdLevel & $40.32^{* * *}(11.05)$ & $44.67^{* * *}(13.12)$ & $50.34^{* * *}(16.64)$ & $61.26^{* * *}(15.07)$ \\
\hline $\begin{array}{l}\text { lnLabProdLevel- } \\
\text { PreYear }\end{array}$ & $-38.13^{* * *}(10.03)$ & $-42.44^{* * *}(12.60)$ & $-48.51^{* * *}(14.32)$ & $-65.31^{* * *}(13.80)$ \\
\hline TFPpre & $0.142^{*}(0.454)$ & $0.129^{* *}(0.827)$ & $-0.153(0.056)$ & $0.116^{*}(0.0627)$ \\
\hline Manuf & $0.171^{*}(0.192)$ & $-1.068(0.381)$ & $-0.009(0.167)$ & $0.613^{* * *}(0.126)$ \\
\hline DummyEU & $-0.183(0.124)$ & $-0.133(0.247)$ & $-0.102(0.012)$ & $-0.876(0.590)$ \\
\hline DummyCrisis2008 & $-3.294^{* * *}(0.370)$ & $-1.339^{* * *}(0.472)$ & $-1.271(0.526)^{* * *}$ & $-1.881^{* * *}(0.372)$ \\
\hline RD & & $10.53(3.297)$ & $4.37(2.109)^{* *}$ & $0.14(2.082)$ \\
\hline Constant & $3.175(15.106)$ & $-7.233(14.030)$ & $-8.953(2.435)$ & $12.28(30.19)$ \\
\hline R-sq & 0.77 & 0.82 & 0.75 & 0.76 \\
\hline $\begin{array}{l}\text { Standard errors in parentheses } \\
* * *\end{array}<0.01,{ }^{* *} \mathrm{p}<0.05,{ }^{*} \mathrm{p}<0.1$ & & & \\
\hline
\end{tabular}

Source: author's calculations

\section{CONCLUSIONS, PROPOSALS, RECOMMENDATIONS}

1. There are only few TFP growth determinants that are revealed by the research. Trade openness is positively associated with the TFP growth in eight European countries. This relation shows that deeper involvement into international trade raises TFP growth. It might be caused by competition due to new export channels or imported substitutes that forces domestic firms to innovate and implement new technologies into production. It is not possible to assume that exactly export or import influences of TFP growth. 
2. Higher education (tertiary) level of labour force is positively associated with TFP growth only in Hungary, Latvia, Lithuania and Slovenia. Its significance level grows with R\&D expenses, and it evidences that labour force with tertiary education has an influence on TFP growth due to accumulation of innovative technologies.

3. Such institutional indicator as government effectiveness index is highly significant contributor to TFP growth, but in the case, when R\&D expenses are taken into account, government effectiveness index loses its power and shows poor contribution to TFP growth.

4. FDI share of GDP, corruption control index and R\&D expenses as a share of GDP do not appear as significant forces that would influence TFP growth. FDI shows poor significance in the case of Estonia and Hungary.

5. Government effectiveness appears as determinant of TFP growth only in Slovenia. In other countries, its influence is poor or none. Corruption control does not appear as determinants of TFP growth at all. It may be due to small share of corruption in the countries and effective governmental environment overall.

6. The applicability of the results is restricted to eight EU countries. Future researches may assign the same TFP growth determinants to the whole union.

\section{REFERENCES}

Barro, R. J., 2001. Human Capital and Growth, The American Economic Review, Vol. 91, No. 2.

Becker, S. O., Egger, P. H., von Ehrlich, I., 2010. Going NUTS: the Effect of EU Structural Funds on Regional Performance, Journal of Public Economics.

Borensztein, E., De Gregorio, J., Lee, J.-W., 1998. How Does Foreign Investment Affect Economic Growth? Journal of International Economics, 45.

Denison, E. F., 1962. The Sources of Economic Growth in the United States and the Alternatives Before Us, Committee for Economic Development, Supplementary Paper No. 13.

Djankov, S., Hoekman, B., 2000. Foreign Investment and Productivity Growth in Czech Enterprises, World Bank Economic Review, Vol. 14, Issue 1.

Grossman, G. M., Helpman, E., 1994. Endogenous Innovation in the Theory of Growth, The Journal of Economic Perspectives, Vol. 8, Issue 1.

Iacovone, L., De Hoyos, R. E., 2011. Economic Performance under NAFTA: A FirmLevel Analysis of the Trade-Productivity Linkages, The World Bank Policy Research Working Paper 5661.

Jorgenson, D. W., Griliches, Z. 1967. The Explanation of Productivity Change, Review of Economics and Statistics, July.

Kendrick, J. W. 1961, Productivity Trends in the United States, Princeton University Press

Solow, R. M., 1957. Technical Change and the Aggregate Production Function, The Review of Economics and Statistics, Vol. 39, No. 3.

The Conference Board, Productivity Brief 2015. [Online] Available at https://www. conference-board.org/retrievefile.cfm?filename=the-conference-board-2015productivity-brief.pdf\&type=subsite [Accessed 10 September 2017] 


\title{
FORENSIC ACCOUNTING IN THE WORLD: PAST AND PRESENT
}

\author{
JULIA LIODOROVA \\ VALERIYA FURSOVA
}

\begin{abstract}
The authors describe the historical evolution of forensic accounting and forensic accountant's profession based on the survey of foreign studies. The authors focus on identifying the common characteristics and the main differences in forensic accounting status, typology, and methodology. The present article also provides a comparison of conditions of forensic accountants' certification in countries based on the Romano-Germanic and Anglo-Saxon legal systems. The authors demonstrate the application area of forensic accounting and substantiate the topicality of forensic accounting application to fraud investigation. The present study makes a comparison between forensic accounting and auditing. The authors also provide relevant information on forensic centres, where the accounting examinations are carried out, and organisations that certify the forensic accountants.
\end{abstract}

Key words: forensic accounting, accounting examination, historical review, forensic expert, case of Latvia

JEL code: K13, M48, M42

\section{INTRODUCTION}

The evolution of forensic accounting and forensic accountant's profession is related to historical events, which explain the differences in the status of accounting examinations and their approach in different countries that have different legal systems. There are many foreign studies devoted to the experience of forensic accounting and fraud examination, which demonstrate the necessity and importance of research in this area. Despite the fact that the institution of forensic accounting has existed for already 20 years in Latvia, there is no regional study of Latvian practice and its comparison with other countries.

The aim of the research is to analyse the evolution of forensic accounting and profession of forensic accountants in the world, identifying the common characteristics and the main differences in countries with different legal systems to improve understanding of the specifics of each system for the development and unification of common forensic accounting institute. The tasks of the research are to collect information on forensic accounting and its performers in the world and separately in Latvia, to investigate its evolution and to reveal the common 
characteristics and the main differences in countries based on the RomanoGermanic and Anglo-Saxon legal systems.

The first part of the study provides a brief literature review of the studies on forensic accounting, which justifies the topicality of the study. The second part provides the retrospective information on the development of forensic accounting and profession of forensic accountant, which makes it possible to understand its specificity and the difference from other types of inspections. The comparison between forensic accounting and auditing is made in the third part. The fourth part describes the status of forensic accounting and its performers in the world, including a case of Latvia at present.

The scientific research methods such as bibliographic and historical review, bibliometric research, analysis of theoretical text (conceptual analysis, comparison, and aperture) are used in this research.

\section{LITERATURE REVIEW}

According to D. Larry Crumbley, the phrase "forensic accounting" was coined in print for the first time in 1946 by Maurice E. Peloubet, who stated that forensic accounting was not only practiced in courtrooms, but was involved in what was essentially a type of forensic practice (Crumbley, Heitger and Smith, 2005). Forensic accounting is the specialty area of the accountancy profession, the results of which are used in actual or anticipated disputes and litigation. "Forensic" means "suitable for use in a court of law", and it is to that standard and potential outcome that forensic accountants generally have to work (Ozkul and Pamukcu, 2012).

Forensic accountants, who in many countries are called forensic experts, fraud examiners or forensic accounting investigators, perform these functions. These specialists work at different police and state institutions, science institutes, large audit companies or operate in private practice. Forensic accountants are trained and experienced in resolving financial disputes through document analysis to include both financial and nonfinancial information, interviewing, and third party inquiries. Forensic accountants are members of a broad group of professionals that includes those who perform financial investigations, but it is actually wider (Skalak, Alas and Sellito, 2006).

Accounting examination may be criminal accounting expertise related to forensic crime investigation or related to accounting of damages in civil proceedings, such as insurance. They have further specialisations: accounting, economic calculations, insolvency diagnostic, fraud detection in financial statements, assets misappropriation, tax evasion, money laundering, business evaluation, etc. There is a broad approach to defining the performance of accounting examinations, since it can act in Labour, Civil and Criminal justice and in the extrajudicial area (Santos Filho, Carlos and Costa, 2017). 
The conclusions of the experts are based on an expert study of objects carried out by special knowledge and scientifically based methods. The subject of accounting examination is documented information about facts and events of economic activity, which is often identified with the help of an accounting document, since the latter is a paper or electronic certificate confirming an economic transaction or economic event and possessing requisites for determining an economic transaction or event (Barkauskas, Speciute and JuodkaiteGranskiene, 2016).

In Latvia, accounting examination is registered in the classification list of the forensic examinations with No 11.02 and it is described as "research and analysis of bookkeeping registers, reports and financial activities" (Cabinet Regulation, 2016). Accounting examinations are carried out to obtain documentary evidence and to evaluate their result in money equivalents, if non-compliance with the requirements of regulatory enactments has been found, which created financial consequences (Peisniece et al., 2015). The accounting examinations are performed at the Forensic Service Department of the State Police of Latvia, and it can be held by private experts.

Sixty-three scientific articles about forensic accounting and forensic accountants are registered in the database "Scopus" for period from 1992 to 2017. The leader of number of publications is USA (29 articles), the next is Canada ( 6 articles), then follow Australia and Nigeria (each for 4 articles), the next are China, Germany, Malaysia and India (each for 3 articles), the next are UK and South Korea (each for 2 articles), then follow Hong Kong, Indonesia, Slovenia,

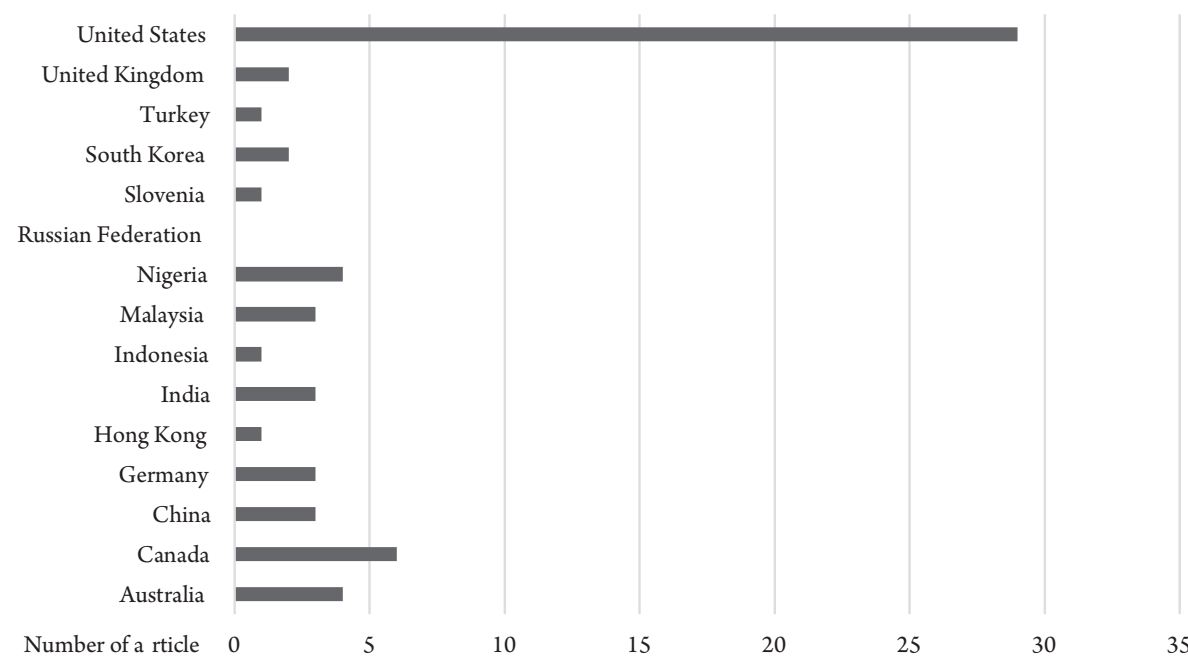

Source: author's construction based on Scopus data

Fig. 1. Scientific Articles about Forensic Accounting by Country, registered in Scopus database 
Turkey (each for 1 article) and Russian Federation (1 common article with USA), see the Figure 1. The highest number of articles are published starting at 2008, and the number of articles is growing by each year.

The main authors, who publish articles about forensic accounting, by Scopus data, are C. Durtschi, W. D. Hurber, B. Waldrup and Z. Rezaee (USA), R. Dong (China), S. Bhattacharya and K. Kumar (Australia), L. S. Rosen (Canada), V. J. Shea (UK), and others.

There are many foreign scientific studies about forensic accounting and economic examinations published by forensic institutions, such as the State Forensic Examination Committee of the Republic of Belarus, Kyiv Research Institute of Forensic Expertise, Russian Federal Centre of Forensic Expertise, National Bureau of Expertise of Armenia, etc. There are many publications about forensic accounting and fraud examinations presented by international professional associations, such as the Institute of Certified Public Accountants (AICPA), Association of Certified Fraud Examiners (ACFE), National Association of Certified Valuators and Analysts (NACVA), etc.

The professions of forensic accounting expert and certified auditor have existed for 20 years in Latvia, having undergone a dynamic development. There are some studies about service quality of certified auditors (Dañēviča, Aizsila and Ikaunieks, 2013), the development and application of auditing standards in Latvia (Ponomarjovs, 2005). On the other hand, only a few articles about forensic accounting were published in Latvia and the Baltic States.

\section{FORENSIC ACCOUNTING IN THE PAST}

Without studying the history of a particular phenomenon, one cannot understand this phenomenon in its modern sense, which was confirmed by Professor I. F. Krilov in the 20th century (Gasparyan, n. d.).

Historians believe that record keeping originated about 4000 B.C., when ancient civilizations in the Near East began to establish organised governments and businesses (Montgomery, 1998). It has been assumed that the accounting records came about to capture the most significant facts of economic life that had an impact on the legal consequences. Such consequences were often evidence of disputes initially addressed at the domestic level, but with the emergence of courts - at the legal level (Gasparyan, n. d.). The legal approach to bookkeeping had an impact on its personalisation, thereby accounting objects are no longer just objects (real estate, goods, materials, money), but the rights and obligations of an economic entity. Thus, the necessity of accounting examination is mainly based on the conformity of the inventory of material assets with the actual situation and the control examination on the rational distribution of these values among the members of the society and their legal relations (Zavyagin and Shirimov, 2013).

There are numerous examples in the ancient world of auditing and control procedures employed in the administration of public finance systems. The Shako 
dynasty of China (1122-256 B.C.), the Assembly in Classical Athens, and the Senate of the Roman Republic - all exemplify early reliance on formal financial controls (Montgomery, 1998). In the Middle Ages, for the consideration of property disputes in court instances, competent persons who represented one of the parties began to be invited for accountancy. With the development of the accountant profession in the 13th century, the court practice widely used the conclusions of knowledgeable accountants in the handling of claims for damages, late payment, etc. (Gasparyan, n. d.).

Much later, in the 12th and 13th centuries, the auditing work was performed in England, Scotland, Italy, and France. The audits in Great Britain, performed before the 17th century, were primarily directed towards ensuring the accountability of funds entrusted to public or private officials (Montgomery, 1998). Those audits were not designed to test the quality of the accounts, except insofar as inaccuracies might point to the existence of fraud. Economic changes between 1600 and 1800, which saw the beginning of widespread commerce, introduced new accounting concerns focused on the ownership of property and the calculation of profit and loss in a business sense. At the end of the 17th century, the first law prohibiting certain officials from serving as auditors of a town was enacted in Scotland, thus introducing the modern notion of auditor independence (Montgomery, 1998).

Along with the development of audit, to resolve financial disputes, it began popular to attract other professionals - auditors and inspectors - to replace accounting examination with audits in countries based on the Anglo-Saxon legal system.

Studies demonstrate that since 1830 auditors of Great Britain mainly focused on detecting fraud in companies operating in the public sector rather than focusing on accounting audits. In the 1930s, the disclosure of fraud risks was one of the mandatory tasks of auditors, but not the main one (Chandler, Edwards and Anderson, 1993). Publications of auditors of Great Britain have contributed to the development of forensic accounting in North America. Along with the development of the economy and the growth of company volumes, it became clear that it would not be possible for auditors to detect all fraud risks at the time of the audit. As a result, in the 1950s, the term "forensic accounting" was coined in the United States, which initially meant the gathering of evidence or expert testimony to the court about corporate turnover and asset values, not relating them to fraud detection and prevention (Stevenson, 2015).

One of the most well-known cases of forensic accountancy is the capture of $\mathrm{Al}$ Capone, where a team of forensic accountants gathered information in an irrefutable case against Capone in 1931 (Dreyer, 2014). In 1949, Edwin Sutherland published his first edition of White-Collar Crime, in which he detailed the criminal behaviours of the largest US corporations at the time (Salinger ed., 2013), highlighting the new field of issue.

Forensic accounting proved its importance after the Second World War, but its procedures were only introduced in the 1980s when scientific research was 
published in this area (Ozkul and Pamukcu, 2012). The development of forensic accounting in Great Britain and the USA was related to the loud fraud scandals in the 1970s, such as the Enron case, in which investors of audited companies lost millions. As a result, requirements for bookkeeping and internal control systems were reinforced by separating auditors from accounting experts (Stevenson, 2015).

There are significant differences in the historical development of forensic accounting in countries based on the Romano-Germanic legal system.

In France, these differences are mainly due to the early inclusion of accounting in the judicial system. By focusing on determining the role of the state in the economy in order to prevent fraud and legal conflicts with offenders, the requirements for bookkeeping with regard to commercial law had already been introduced in the French Code of Commerce in 1673 (Labelle and Saboly, 2008). According to research by Crumbley, forensic accounting was started in France in 1817, when the accountant was used as an expert witness in the court case of Meyer v. Sefton in 1817, related to bankrupt estate (Labelle et al., 2008; Dreyer, 2014). However, in France, the development of professional organisations in the field of accounting was closely related to national priorities rather than private sector initiatives; therefore, "forensic accounting" as a specialty developed slowly because in France it was not officially recognised (Labelle and Saboly, 2008).

In Russia, the development of forensic accounting has a different path from other countries. Forensic accounting in the territory of the former Russian Empire is the result of the Great Judicial Reform in 1864 launched by Alexander II, summarising the experience of Prussian, Austrian, Belgian and French control systems (Zavyagin and Shirimov, 2013). Forensic accounting methods of Russia were formed as a result of the inspections of state institutions, which were mainly based on comparison of actual facts with the requirements of the regulatory enactment (Zavyagin and Shirimov, 2013). Before the Revolution, the accountant's findings in the criminal law of the Russian Empire were often considered explanatory, not recognising the accounting specialist as an expert. However, in the 20th century, the accountant's findings began to be used directly in the criminal investigations because investigators and judges could not cope without specialised knowledge in accounting. In turn, investigative and judicial authorities did not want regular accountants-specialists (Zavyagin and Shirimov, 2013). The scientific and practical approach to accounting examination was initiated in Soviet Russia in the 20th century. As a result, in 1925, the National Accounting Expert Institute was established with a wide network of republics and regions, which was responsible for conducting expert assessments at the request of the courts and administrative authorities.

In Latvia, the first step in the creation of independent audit was taken in 1938, creating the Latvian Institute of Sworn Auditors, which operated under the supervision of the Latvian Chamber of Commerce and Industry. This institute was liquidated in 1940, but their duties and materials were given to state control 
(Ponomarjovs, 2005). In the Soviet period, since 1940, with the exception of the Second World War, the control system in Latvia had been carried out in accordance with the laws and regulations of the USSR (Malderis, 2004). In 1991, after restoration of the independence of the Republic of Latvia, the previously existing system was taken over. Regulation No. 67 of the Cabinet of Ministers of the Republic of Latvia "Regulations for Conducting Revisions upon Request of the Process Facilitator" was approved on 19 March 1996. The Regulation determines the procedure for carrying out a revision of economic and financial activities at the request of an official treating the case, a prosecutor, a judge or a court. In the initial version of the Regulation, the reviser was considered to be a statutory auditor, an audit firm, an internal audit unit of a ministry or a central government institution (Cabinet Regulation, 1996). In 1998, a significant amendment was made in the Regulation - the right to conduct revisions was also granted to the Revision Division of the State Police Expertise Centre (Cabinet Regulation, 1998).

The development of the common legal system in the country, including the adoption of the Criminal Procedure Law in 2005, prompted the need for changes in the field of expert examination. On 14 September 2006, the Saeima adopted the Law on Forensic Experts (the new Law on Forensic Experts was adopted on 11 February 2016), which clarified the legal regulation of forensic examination in Latvia and established common requirements for experts in all fields, incl. bookkeeping. Thus, accounting specialists, previously called revisers, were included in the common unified forensic expert system, and a revision, at the request of the process facilitator, changed its name to accounting examination without changing its nature.

\section{FORENSIC ACCOUNTING IS NOT THE SAME AS AUDIT}

In the conditions of a market economy and an advanced audit, the services of not only forensic experts but also other experts - auditors - are often used to conduct accounting examinations. According to the above-mentioned considerations, a question arises: what is the difference between forensic accounting and auditing?

Apparently, auditing and forensic accounting operate in one area, but each goes its own way. An audit is an examination of a subject; in forensic accounting, the subject is financial (Loper, 2013). Usually auditors check for the compliance of a company's books to generally accepted accounting principles, auditing standards, and company policies (Bhasin, 2016). Forensic accounting is a financial examination within the judicial system (Loper, 2013). The subject of forensic accounting is the action of identifying, recording, settling, extracting, classifying, reporting and verifying past financial data or other accounting activities to solve current or potential legal disputes, or using such past financial data to project future financial data to solve disputes (Crumbley, Heitger and Smith, 2013). 
Auditor's main aim is the annual report auditing, during which they may face fraudulent reports. Forensic accountants' practice includes both fraud investigations and disputes not involving fraud. Thus, there is a correlation between forensic accounting and auditing in the work of preventing and combating fraud (Santos Filho, Carlos and Costa, 2017).

During the course of an audit, an auditor seeks to detect errors or improprieties, lack of specific information where such improprieties exist (Skalak, Alas and Sellito, 2006). Forensic accounting is often deductive because it starts with a specific proposition (Loper, 2013). The audit report is based on the selection of documents; however, forensic accounting examines all documents related to the problem under review. During an examination, a forensic accountant seeks to discover the full methods and extent of improprieties that are suspected or known (Loper, 2013). Auditors have no responsibility to plan and perform audit procedures to detect errors that are not considered significant (including those caused by error as well as fraud) (Santos Filho, Carlos and Costa, 2017). Forensic accountants identify a fraud, applying their professional skills and practices to dispute financial issues; are ready for questions in the courts (Loper, 2013); their conclusions are supported with references of legislation acts. The result of auditors' work is mainly professional opinion about annual report quality and compliance with the accounting international standards. In some cases, the auditor may work directly with attorneys in a dispute to compel production of documents and supporting materials for analysis (Loper, 2013).

Forensic accounting complements the gap in expectation of the audit result, which raised issues on a number of aspects, such as the role and responsibilities of the auditors; the nature and significance of the audit report releases; the quality of the auditor role; and the structure and regulation of the profession (Santos Filho, Carlos and Costa, 2017).

Nowadays there are many types of performers in forensic accounting, such as forensic expert, forensic accountant, forensic auditor, fraud examiner, fraud investigator, etc. The working area of all these performers is specific, but it is based on common principles. In the international area, criminal accounting is called forensic accounting (Santos Filho, Carlos and Costa, 2017).

In professional work, the sworn auditors comply with the code of ethics and the international auditing standards. The activities of auditors are regulated by internal law and monitored by professional associations. In the countries that have the Anglo-Saxon legal system, in professional work forensic accountants comply with the principles based on international guidelines under audit rules; their activities are not specified by law, but are monitored by professional associations (Santos Filho, Carlos and Costa, 2017). In countries that have the RomanoGermanic legal system, forensic accountants comply with the developed internal forensic methods approved by justice system; their activities are specified by law and monitored by the justice system. Regardless of the judicial system, like the auditors, all forensic accountants comply with the code of ethics. 
The comparison of forensic accounting and auditing is shown in Table 1.

The Comparison of Forensic Accounting and Auditing

\begin{tabular}{|l|l|l|l|}
\hline \multicolumn{1}{|c|}{ Position } & \multicolumn{2}{c|}{ Forensic accounting } & \multicolumn{1}{c|}{ Auditing } \\
\hline Legal system & Romano-Germanic law & Anglo-Saxon law & Both cases \\
\hline Performer & Forensic expert & $\begin{array}{l}\text { Forensic accountant } \\
\text { Fraud examiner }\end{array}$ & Auditor \\
\hline Legislation & Law, Code of ethics & Code of Ethics & Law, Code of Ethics \\
\hline Accountability & Justice system & Professional association & Professional association \\
\hline Participation in & $\begin{array}{l}\text { litigations; } \\
\text { Fraud investigation }\end{array}$ & $\begin{array}{l}\text { Participation in } \\
\text { litigations; Fraud } \\
\text { investigation; Professional } \\
\text { services }\end{array}$ & $\begin{array}{l}\text { Financial report auditing; } \\
\text { Professional services }\end{array}$ \\
\hline Methodology & $\begin{array}{l}\text { Evidences determination } \\
\text { forensic investigation } \\
\text { under justice system }\end{array}$ & $\begin{array}{l}\text { Evidences determination } \\
\text { International guidelines } \\
\text { under audit rules }\end{array}$ & Financial auditing \\
\hline Product & $\begin{array}{l}\text { Forensic examination } \\
\text { conclusion }\end{array}$ & $\begin{array}{l}\text { Fraud case report; } \\
\text { Forensic audit report }\end{array}$ & Audit standards \\
\hline
\end{tabular}

Source: made by the authors

\section{FORENSIC ACCOUNTING IN THE PRESENT}

Many aspects of the shifting world, including the history, economy, society, and legislation, have moulded the profession of forensic accountant. The development of the profession was facilitated by several reforms in the performance of financial statements, as well as occupational fraud at the international level. It has already been recognised as a separate profession in countries based on the RomanoGermanic legal system, as in Latvia; in countries with the Anglo-Saxon legal system this road has just begun.

Forensic accountants have been requested in areas such as corporate fraud, money laundering and even terrorist financing disclosure. Nowadays, forensic accountants work at the independent forensic institutions; are involved in work with national controlling organisations and investigative institutions; they provide not only testimonies to the courts, but also publish studies on detected cases of fraud and their trends.

In general, in the countries that are based on the Romano-Germanic legal system, forensic accounting is specified profession, and requirements for this profession are similar: education, work experience, certification, etc. The types of examinations, their tasks and methodology are basically the same. 
Due to the subordination of the Forensic Service Department to the State Police, today forensic accounting examination in criminal proceedings is mainly being carried out in Latvia. More often than not, forensic examination is required in the investigation of economic crimes related to fraud and misappropriation. However, expert examination is also provided in insolvency proceedings, real estate management and the public sector to detect shortcomings and illegal seizure; there is also an increasing demand for accounting examinations in tax matters.

Accounting examination is carried out in compliance with the requirements set out in the Law on Forensic Experts and other regulatory enactments, according to the methods established by the Council of Forensic Experts. Requirements for forensic experts are established in the Law on Forensic Experts, according to which the following natural person may be a forensic expert candidate: a person with an impeccable reputation who has acquired an accredited study programme corresponding to the speciality chosen (economics) at a higher education institution and obtained professional knowledge and experience of a forensic expert (acquired a specialised training programme) at a forensic expert examination institution or under the supervision of a forensic expert (Law of the Republic of Latvia, 2016).

A forensic expert candidate shall take an examination in the presence of a commission specially created by the Council of Forensic Expert. The examination consists of two parts: the legal part (written examination) and the professional part (oral examination). Applying for the examination, applicants shall submit a copy of the document attesting education of the candidate, CV, a copy of the individual training plan and attestation for completing training, ten conclusions of the research carried out, and the qualification paper elaborated during training that is also subject to review (Cabinet Regulations, 2016).

Every five years there is a need for a recertification procedure, which is accompanied by documents attesting the qualification and competence of a forensic expert - a report on activities related to the speciality of the forensic expert and documents attesting thereto issued during the term of validity of the certificate and a letter of recommendation from the head of the expert centre, court, prosecutor's office or investigative body. The forensic expert has a minimum required level to complete for recertification and it includes the conduct of expert examination (optimal number 10), participation in training, conferences, publications, training of candidates, etc. (Cabinet Regulations, 2016).

Information about forensic experts certified in the Baltic States is provided in the Register of the Council of Forensic Experts. In 2017, the Code of Conduct for Forensic Experts has been developed, which all forensic experts, including accounting experts, should follow.

In former USSR countries, which historically followed the rules of the Russian empire, certified forensic experts who have similar qualification requirements as in the Latvian legislation also carry out accounting expertise. The right to 
carry out an expert examination is obtained through certification, confirming competence in the recertification procedure every five years. In fact, an expert examination is carried out by internationally accredited examination centres under the jurisdiction of the Ministry of Justice or the Ministry of the Interior or by autonomous institutions.

The summary of the forensic centres, where forensic accounting examinations are carried out, as well the types of examinations are presented in Table 2.

Table 2

Forensic Centres Carrying out Forensic Accounting Examinations

\begin{tabular}{|c|c|c|c|c|}
\hline Country & Accountability & Examination & Types & Website \\
\hline Latvia & $\begin{array}{l}\text { Ministry of the } \\
\text { Interior }\end{array}$ & Accounting & no separation & ekspertize.vp.gov.lv \\
\hline Lithuania & $\begin{array}{l}\text { Ministry of the } \\
\text { Interior, Ministry of } \\
\text { Justice }\end{array}$ & Economical & $\begin{array}{l}\text { accounting, financial, } \\
\text { banking, labour economics }\end{array}$ & $\begin{array}{l}\text { policija.lrv.lt } \\
\text { ltec.lt }\end{array}$ \\
\hline Estonia & Ministry of Justice & Accounting & $\begin{array}{l}\text { accounting, } \\
\text { financially analytical }\end{array}$ & ekei.ee \\
\hline Belarus & $\begin{array}{l}\text { Independent } \\
\text { institution }\end{array}$ & Economical & no separation & sudexpert.gov.by \\
\hline Russia & $\begin{array}{l}\text { Ministry of the } \\
\text { Interior, Ministry of } \\
\text { Justice }\end{array}$ & Economical & $\begin{array}{l}\text { accounting, credit-related, } \\
\text { financially analytical, tax }\end{array}$ & $\begin{array}{l}\text { ceur.ur } \\
\text { sudexpert.ru }\end{array}$ \\
\hline Kazakhstan & Ministry of Justice & Economical & $\begin{array}{l}\text { accounting, credit-related, } \\
\text { budget, etc. }\end{array}$ & $\begin{array}{l}\text { sudexpert.adilet. } \\
\text { gov.kz }\end{array}$ \\
\hline Georgia & $\begin{array}{l}\text { Independent } \\
\text { institution }\end{array}$ & Financial & no separation & forensics.ge \\
\hline Armenia & $\begin{array}{l}\text { Independent } \\
\text { institution }\end{array}$ & Economical & $\begin{array}{l}\text { accounting, financially } \\
\text { analytical, separation of } \\
\text { equity, etc. }\end{array}$ & nbe.am \\
\hline Ukraine & $\begin{array}{l}\text { Independent } \\
\text { institution, Ministry of } \\
\text { the Interior }\end{array}$ & Economical & $\begin{array}{l}\text { accounting, } \\
\text { financially analytical }\end{array}$ & $\begin{array}{l}\text { nise.com.ua etc. } \\
\text { no information }\end{array}$ \\
\hline Moldova & Ministry of Justice & $\begin{array}{l}\text { No } \\
\text { information }\end{array}$ & $\begin{array}{l}\text { accounting, banking } \\
\text { economical, etc. }\end{array}$ & lex.justice.md \\
\hline
\end{tabular}

Source: made by the authors based on the information at the websites

In Poland, Austria and France, the status of forensic accounting expert for a period of five years is granted by the court registering the chosen person in special registers. Requirements for a candidate are similar to that of the abovementioned countries - higher education in the field, professional experience; in addition, recommendations are required from professional associations (in Poland), from the court (in France, Austria) or from the prosecutor's office (in Austria). In France, unlike Poland and Austria, candidates are required to pass a 
qualification examination in the presence of a specially created court committee. After expert registration, French and Austrian experts become members of the National Association of Forensic Experts (Spečiūte et al., 2013). However, an accounting expert is not a profession in these countries; the persons selected for this status are imposed obligations before the court (Huber and Charrier, 2015)

In some countries, accounting examinations are called economic or financial, in several countries they are separated by types:

- accounting examination (accountancy records analysis, detection of noncompliance);

- financially analytical examination (financial situation evaluation, determination of insolvency reasons);

- credit-related, banking examination (research of compliance to the principles of lending);

- tax examination (research of the tax accruals and legislation compliance);

- labour economics examination (research of the wage calculation); and

- examination of separation of equity and profit (research on the distribution of capital / profits according to the investment made), etc.

Expert examination methods are altogether alike, but there are nuances in expert competence and research approaches. For example, Lithuanian and Belarusian experts categorically disassociate themselves from resolving the legal issues; thus, they do not determine the level of responsibility of officials. Kazakhstani experts carry out expert examination only in cases when the accounting documents are properly arranged. Belarusian experts do not conduct tax examination. In Lithuania, Armenia, as well as in other countries accounting examination is also considered property and business evaluation.

In countries based on the Anglo-Saxon legal system, forensic accounting is a relatively new profession that started its evolution centuries ago.

Due to large financial fraudulent scandals, for example, Enron, Tyco, WorldCom, there has been an increased demand for audits and scrutiny of all companies. The Sarbanes-Oxley of 2002 set major requirements for accounting, management and auditors, and opened up a completely new field of investigation for forensic accountants (Dreyer, 2014).

Now all of the large accounting firms such as KPMG, Deloitte, BDO and PWC have forensic accounting departments (Ozkul and Pamukcu, 2012). Since 1960s, the FBI has been employing over 700 special agent accountants, who investigate cases of financial fraud, crimes over the Internet, money laundering, and many other economic crimes (Dreyer, 2014).

Forensic accountants are needed for investigation of the following crimes: theft of physical assets; management conflict of interest; vendor, supplier and procurement fraud; billing, expenses reimbursements, tampering, etc. However, corporate fraud is just one area that forensic accountants deal with. Forensic accountants analyse the estimates for claims, as it was in the Hurricane Katrina 
case in 2005 (Dreyer, 2014), make the property and business evaluation, etc. Thus, there is not directly specified area of accounting examination and its separation in these countries.

In the United States, the United Kingdom and other countries based on the Anglo-Saxon law, accounting forensic examinations are carried out by certified accountants as a type of service, while recognising these professionals by particular profession; in Canada, a forensic accountant is considered a profession (Ozkul and Pamukcu, 2012).

Forensic accountant must not only master the accounting techniques, but also specific forensic techniques - quantification of damage, etc. - the rules of procedure and evidence (Huber and Charrier, 2015). After forensic functions were clearly delineated, they were formally incorporated into the certification and training programmes of professional organisations and universities, such as the American Institute of Certified Public Accountants (AICPA), Canadian Institute of Chartered Accountants (CICA). Such courses offered by American organisations are based on the white-collar crimes prevalent in the USA.

Now the following professional associations provide recognition of forensic or fraud accounting certification and education (Stevenson, 2015), which are presented in Table 3. The largest and most recognised of them is the Association of Certified Fraud Examiners (ACFE) founded in Austin, Texas, in 1988.

Table 3

The Organisations that Hold the Certification of Forensic Accounting

\begin{tabular}{|l|l|l|}
\hline \multicolumn{1}{|c|}{ Organisation } & \multicolumn{1}{|c|}{ Certified specialty } & \multicolumn{1}{c|}{ Website } \\
\hline $\begin{array}{l}\text { The American Institute of Certified Public } \\
\text { Accountants, AICPA }\end{array}$ & Financial Forensic Specialist & www.aicpa.org \\
\hline $\begin{array}{l}\text { The American Board of Forensic Accounting, } \\
\text { ABFA }\end{array}$ & Forensic Accountant & www.certfa.org \\
\hline $\begin{array}{l}\text { The Association of Certified Forensic } \\
\text { Investigators of Canada, ACFI }\end{array}$ & Forensic Investigator & www.acfi.ca \\
\hline $\begin{array}{l}\text { The Association of Certified Fraud Examiners, } \\
\text { ACFE }\end{array}$ & Fraud Examiner & www.acfe.com \\
\hline $\begin{array}{l}\text { The Association of Certified Fraud Specialists, } \\
\text { ACFS }\end{array}$ & Fraud Specialist & www.acfsnet.org \\
\hline $\begin{array}{l}\text { The Institute of Certified Forensic } \\
\text { Accountants, ICFA }\end{array}$ & $\begin{array}{l}\text { Professional Forensic } \\
\text { Accountant }\end{array}$ & www.forensicglobal.org \\
\hline $\begin{array}{l}\text { The Association of Chartered Certified } \\
\text { Forensic Accountants, ACCFA }\end{array}$ & $\begin{array}{l}\text { Chartered Forensic } \\
\text { Accountant }\end{array}$ & www.accfaglobal.com \\
\hline $\begin{array}{l}\text { The Forensic Certified Public Accountant } \\
\text { Society, FCPAS }\end{array}$ & Forensic Public Accountant \\
\hline $\begin{array}{l}\text { The National Association of Certified } \\
\text { Valuation Analysts, NACVA }\end{array}$ & $\begin{array}{l}\text { Master Analyst in Financial } \\
\text { Forensics }\end{array}$ & www.fcpas.org \\
\hline
\end{tabular}

Source: made by the authors based on Stevenson, 2015 
The conditions to the expert-candidates are the same comparing with countries with other law system: education not less of bachelor level (master level in Canada), specific training, experience 2-5 years, free of criminal sanction, all candidates must pass the examination. There are some additional conditions in several associations - candidates must be certified accountants or/and be members of these professional associations. These associations accept the decision of certification. The renewal is automatic each year if experts have professional training during this period (must continuous activity in Canada).

The used techniques of forensic accounting includes the conventional accounting and auditing tools like ratio technique, cash flow technique, a standard statistical tool examination, etc. (Bhasin, 2016). As well, one from more used techniques is the Bedford's Law that is the mathematical tool, and is one of the various ways to determine whether variable under study is a case of unintentional errors or fraud (Bhasin, 2016). In order to be more effective, today's forensic accounting has evolved its processes combined with elements of computer forensic tools (Stevenson, 2015). In cases involving significant amounts of data, the present-day forensic accountant has technology available to obtain of source data, sort and analyse data and even quantify and stratify results through computer audit and various other techniques (Bhasin, 2016), for example Data Mining Techniques.

Worldwide events have triggered the request the demand for forensic accountants also in such countries as the India, China, Turkey, etc. Many universities in United States, Canada, Australia, India, Turkey, etc., offer a high-level degree education of forensic accountants. The field of forensic accounting is advancing in worldwide, with more sophisticated challenges to address and with more sophisticated tools at hand.

\section{CONCLUSIONS}

Institution of forensic accounting was established in the early 20th century, following the historical development in social and economic activities. Forensic accounting as a forensic area and forensic accountants called forensic experts as a particular profession got their judicial status early in countries based on the Romano-Germanic legal system. In the countries based on the Anglo-Saxon legal system, this process began only following the corporate fraud cases at the world level at the end of the 20th century. Forensic accounting as a specific area, which is not the same as audit, has been accepted in these countries only nowadays, but this specialisation has a rapid rate of development. There is not a clear sign that the future of the specialty of forensic accounting, deriving from financial auditing and criminology and developing its own repertoire of goals and methods, will be much longer than it is past.

The types of forensic accounting are specified in the legislative acts in countries based on the Romano-Germanic legal system. There is not a directly 
specified area of accounting examination and its separation in countries based on the Anglo-Saxon law, but issues of examinations are similar to that in the countries with other legal systems.

The conditions for forensic accountants are the same in all countries: education, specific training, experience, free of criminal sanction and obligatory professional examination. However, there are some substantial differences. In countries that have the Anglo-Saxon legal system, the decision of certification is the accountability of professional associations, which are at least eight. In turn, it must be the discretion of the Court Department in countries based on the Romano-Germanic legal system. The renewal of competition is automatic each year in countries that have the Anglo-Saxon legal system; however, the experts from countries that have the Romano-Germanic legal system must have partial or full re-examination each five years.

By comparing the methodology of forensic accounting, it should be stated that, in fact, it is the same based on the audit principles in all countries, substantiating the conclusion with regard to legislative support. Despite the profession recognition, the methods used in countries that have the Anglo-Saxon legal system are more developed and they contain more mathematical approaches and computer tools.

\section{REFERENCES}

Barkauskas, M., Speciute, A., Juodkaite-Granskiene, G., 2016. Ekominiu ekspertiniu tyrimu galimybes tiriant ukines ir finansines nusikalstamas veikas. Law review, 2 (14), 281-305. Available at: https://ejournals.vdu.lt/-index.php/LawReview/ article/view/1248

Bhasin, M., 2016. Forensic Accounting in Asia: Perspectives and Prospects. International Journal of Management and Social Sciences Research, 5 (7), 25-38.

Cabinet of Ministers of the Republic of Latvia. (19.03.1996.) Regulation No. 67. Regulations for Conducting Revisions upon Request of the Process Facilitator. Riga: Latvijas Vēstnesis.

Cabinet of Ministers of the Republic of Latvia. (04.08.1998.) Regulation No. 287.

Cabinet of Ministers of the Republic of Latvia. (20.12.2016.) Regulation No. 834. Procedures for the Certification and Recertification of Forensic Experts.

Cabinet of Ministers of the Republic of Latvia. (20.12.2016.) Regulation No. 835. Regulations on the List of Forensic Institutions and the Classifier of Specialities of Forensic Experts.

Chandler, R. A., Edwards, J. R., Anderson, M., 1993. Changing Perceptions of the Role of the Company Auditor, 1840-1940. Accounting and Business Research, 23, 443-459.

Crumbley, D. L., Heitger, L. E., Smith, G. S., 2005. Forensic and investigative accounting. 2nd ed. CCH Incorporated, Chicago.

Crumbley, D. L., Heitger, L. E., Smith, G. S. 2013. Forensic and investigative accounting. 6th ed. CCH Incorporated, Chicago. 
Daṇēviča, D., Aizsila, I., Ikaunieks, R., 2013. Audit Quality Aspects of Cooperation between Certified Auditor and Audited Entity. Journal of Economics and Management Research, 3, 11-25.

Dreyer, K., 2014. A History of Forensic Accounting. Available at: https://scholarworks. gvsu.edu/cgi/viewcontent.cgi-?article $=1339 \&$ context=honorsprojects

Gasparyan, M. Y., n.d. Тенденции развития судебно-бухгалтерской экспертизы. The world economy. [Online]. Available at: https://www.world-economy.eu/ fileadmin/world-economy/Dokumente/Russ._22\%D0\%A2\%D0\%B5\%D0\%B D\%D0\%B4\%D0\%B5\%D0\%BD\%D1\%86\%D0\%B8\%D0\%B8 \%D1\%80\%D0\%B 0\%D0\%B7\%D0\%B2\%D0\%B8\%D1\%82\%D0\%B8\%D1\%8F_oD1\%81\%D1\%83 \%D0\%B4\%D0\%B5\%D0\%B1\%D0\%BD\%D0\%BE_22.pdf [Accessed 09 January 2018].

Huber, D., Charrier, E. 2015. Is it Time to Regulate Forensic Accounting? Les Cahiers $d u$ Chiffre et du Droit, 3, 104-111.

Labelle, R., Saboly M., 2008. Forensic Accounting in France: Emergence and Development. Journal of Forensic Accounting, 9, 83-94.

Law of Forensic Experts. (14.09.2006.) Riga: Latvijas Vēstnesis.

Law of Forensic Experts. (11.02.2016.) Riga: Latvijas Vēstnesis.

Loper, D. K., 2013. „Forensic Auditing” in Encyclopedia of White-Collar and Corporate Crime. Salinger, L. M. (Ed.), 2nd ed. Vol. 1. Thousand Oaks; New Delhi; London and Singapore: SAGE Publications, pp. 356-359.

Malderis, G., 2004. Grāmatvedība. Revīija. Audits. Riga: SIA “Biznesa augstskola Turība”.

Montgomery, R. H., 1998. Montgomery's Auditing. 12th ed. New York: John Wiley \& Sons, pp. 1-7.

Ozkul, F. U., Pamukcu, A., 2012. Fraud Detection and Forensic Accounting. Emerging Fraud. Fraud Cases from Emerging Economies, 26, 19-41.

Peisniece, L., Zelča, I., Liniņš, K., Narkevics, E.., Logins, M., 2015. Tiesu ekspertīze un noziedziga nodarijuma notikuma vietas apskate. Riga: Valsts policija, pp. 87-92.

Ponomarjovs, A., 2005. Development of the Regulative Requirements of Audit in Latvia. Summary of doctoral dissertation. University of Latvia.

Salinger, L. M. (Ed.), 2013. Encyclopedia of White-Collar and Corporate Crime. 2nd ed. Thousand Oaks; New Delhi; London and Singapore: SAGE Publications.

Santos Filho, C. R., Carlos, F. A., Costa, F. M., 2017. Relevant Skills for Criminal Accounting Expertise: the perception of Federal Police experts and delegates. Journal of Education and Research in Accounting, 11 (1), 69-88.

Skalak, S. L., Alas, M. A., Sellito, G., 2006. Fraud: an Introduction. Chapter 1 in Golden, T. W., Skalak, S. L., Clayton, M. M. A Guide to Forensic Accounting Investigation. New Jersey: John Willey\&Sons, pp. 1-20.

Stevenson, S. G., 2015. The Past, Present, and Future of Forensic Accounting. The CPA Journal, March 2015, pp. 18-20.

Spiečiūte, A., Barkauskas, M., Kuncevic, M., Jansone, A., Zeltīte, A., Liodorova, J., Kangro, I., Liivamae, I. 2013. The economic expertise best practice guide for investigation of the crimes related to bankruptcy and for completion of the experimental insolvency research in the Baltic countries. In: Forensic methods, eds. H. Malevski \& A. Gorbatov. Vilnius: Forensic center of Lithuania, pp. 62-122.

Zavyagin, S., Shirimov, J., 2013, Ретроспективный анализ развития судебно-бухгалтерской экспертизы в России. Вестник Воронежского института МВА России, $2,11-18$. 


\title{
CURRENT APPROACHES TO PUBLIC ADMINISTRATION EMPLOYEE EVALUATION
}

\author{
INETA LAKSTIGALA \\ SIGNE BALINA
}

\begin{abstract}
Human work is increasingly replaced by the new technologies, while the operations are divided and subverted so that there is no way to get along without human resources. Therefore, institutions are unable to dispense with the knowledge and skills of the employees in order to move together and to achieve the objectives pursued. Public administration, as an institution, has its own objectives and tasks, which any employed person needs to be clearly aware of and to understand the importance of their job. Therefore, each official and employee of public administration has their job description, while performance and quality of the work commitments shall depend on the knowledge, skills, personality and competence of the employees themselves. Therefore, the assessment of employees is carried out every year in public administrations, according to certain criteria, for the purpose to measure the quality of work and the compliance of employees in a given position. In the course of the evaluation process competencies, knowledge, professionalism, cooperation and quality of work of the employees are assessed. The purpose of the research is to consider and to clarify the methods of assessment of the employees and the way in which the process of evaluation of employees is taking place. The main questions are: whether consultations are carried out after evaluation and what is the impact of its result on the employee. What skills and competences are required for the public administration employees. The methods used by the research are literature analysis, document analysis and direct observations. The research results will be applied in practice by means of improving the process of evaluation of public administration employees. According to the data obtained, it will be possible to identify what are the affecting factors in the process of evaluation.
\end{abstract}

Key words: Latvia, competence, evaluation, knowledge

JEL code: M59, M12, D89

\section{INTRODUCTION}

Today, the knowledge and competence of employees is of great importance since the competencies, knowledge, performance of job assignments and responsibilities of the employees are assessed in accordance with the performance criteria for those employed by the public administration. The evaluation process assesses compliance of the employee with a particular position and the need to improve any knowledge, qualifications, or skills. Therefore, subjective assessment should be avoided in the performance evaluation process. A major role in the 
evaluation process is played by communication and interaction, for the manager to discuss the procedure and outcome of the evaluation process with their subordinate.

The evaluation process results in a potential assessment of the achievements of the institution's staff, the problems that appeared through the work and the factors affecting it, leading to a possible objective set in order to improve the performance, development of qualifications, professional knowledge and competencies of the employees.

\section{EVALUATION OF THE PERFORMANCE}

Evaluation of the performance of those employed with an institution is playing a practical role for determination of their office remuneration, career opportunities, dismissal, ensuring motivation of the employees and the possibility for assessing the skills, performance, knowledge and training requirements of the employees. In the process of evaluation of performance, it is clarified how people should be reached and managed in order to attain the desired outcome (Armstrong, 2004). In order to continuously develop there must be five abilities:

- ability to create and disseminate a single vision,

- ability to share knowledge and to learn in a team,

- ability to develop proficiency by motivating the organisation staff, constantly searching and acquiring additional knowledge,

- ability to identify, to evaluate and to change the way of thinking of members of the organisation, and

- ability to apply systems approach by means of distinguishing processes as a systematic and a cyclical interconnected network rather than a linear chain of events (Senge, 1997).

The evaluation process focuses on the incidence of errors, failures, quality, organisational skills, interpersonal and communication skills.

One of the objectives of the performance evaluation shall be to assess the performance according to the evaluation criteria (the work result, competencies, motivation, satisfaction, ensuring feedback, planning of training and development); to identify what knowledge and skills must be improved. "The choice of an evaluation method shall be determined by the purpose of evaluation. Depending on the purpose, the employee's competency, performance, the work result or the employee's behaviour shall be assessed. The evaluation process can be considerably facilitated by developing and implementing evaluation criteria and a list of competencies. In turn, it is possible for each criterion to define and to describe the assessment levels by means of scoring, percentage systems or verbal descriptions, evaluation of specific requirements, standard behaviour characterization" (Dombrovska, 2009, 77). The evaluation should be considered to be an opportunity for growth, reflecting the works performed and 
achievements made in determining whether the set target and objectives have been achieved. "Competency approach in this time, which is full of challenges, offers a human resource management method widely used in selection, career planning, performance assessment and staff development" (Spencer, Spencer, 1993). In the evaluation processthe same principles are followed (Armstrong, 2007), the manager shall assess:

- how are the objectives, job responsibilities and tasks fulfilled;

- quality, deadlines for implementation of the work results;

- competencies, behaviour, actions, knowledge;

- amount of work, workload;

- working conditions (problems, nuisance factors);

- level of satisfaction of the employees; and

- career planning.

"The objective of managers in the evaluation process shall be: to establish a reciprocal, free dialogue, to understand the employee and to be understood, to provide support to the employee, to carry out an overview of the results attained and unattained, by means of evaluation of the incentive factors, to identify the performance obstacles, to identify the potential and to evaluate the competency of the employee, to set new work targets and to evaluate the work performed" (Ešenvalde, 2008, 135). In a given period of time, it is possible to assess the contribution of the employee, the quality of their work, the problems encountered in the work process. Therefore, the purpose of evaluation of the performance shall be to create the desire for employees to improve and to enhance their work (Latham, Wexley, 1977).

Performance of the job responsibilities may be not always depending upon the employee in charge, due to the fact that the colleagues, the customers and the manager may affect it. Therefore, the evaluation process is a "sensitive" process and, when assessing the performance, there is a possibility for subjective assessment. The evaluation respects equivalent principles of evaluation, the employee learns what is falling within their competence, while one can watch the way it happens (Armstrong, 2004). The evaluation process makes it possible to determine whether the objective pursued has been achieved, and what work is contributed, whether the institutions take care of professional growth and development of their employees, participate in the improvement of communication and interaction, regulate pay changes and reduce staff turnover.

\section{PERFORMANCE EVALUATION SYSTEM IN PUBLIC ADMINISTRATION}

In the public administration are using the Performance Evaluation System the Information System of the Electronic Evaluation Form (hereinafter referred to as the NEVIS). But before the introduction of NEVIS, forms were used to 
evaluate the performance of work, which could be filled in both handwritten and computerized, but the forms were signed on paper and stored in paper. Therefore, one of the goals of NEVIS implementation is to reduce the volume of documents. The evaluation system is focused on knowledge and skills whilst less on competencies.

Knowledge, as well as the competencies, are of great importance today (Alvesson, 2004). Each year (at the beginning of the year), the objectives of the institution shall be set, where in accordance with the structure of the institution, the intended performance tasks shall be set. The objective of evaluation of the performance shall ensure consistency between the institution, entity objectives, values and behaviours, by ensuring fairness and transparency evaluation and building a framework for linking between performance assessment and remuneration, growth of employees and ensuring communication (Armstrong, 2006).

The evaluation system involves a number of problems (Latham \& Latham, 2000). Due to the fact that the employees' knowledge, abilities and skills are not linked to the assessment, the evaluation process, a possibility to encounter a formal employee evaluation or self-assessment - in a short and concise manner: a reply written for form only or "to versify". In the evaluation process, it is important to assess the performance of subordinates, the need for training, the opportunities for growth, and, if necessary, by attracting specialists. It is important that evaluation of the performance should take place in the light of the principle of honesty and equality. When assessing an employee, it is always necessary to build on the previous assessment in order to define more precisely the changes in the performance, knowledge and competency (Covey, 2013).

In the evaluation process, it is important to avoid criticizing an employee, but to see the positive aspects, to say good things, and to recommend improving and developing shortcomings. The manager needs to find out what is an obstacle and problems that interfere with performance of the job assignments in good quality in order to help an employee within the limits of opportunity. In order to say good words, every manager themselves have to work with it, observe good things and be able to assess the accomplishments, because it is possible to achieve better productivity with positive attitude. Mutual understanding and properly used communication should therefore play a highly important role for the employee to feel necessary and to be assessed appropriately. The manager must be open for communication with any employee, regardless of human character and temperament.

Highly qualified, competent and motivated staff is one of the most important conditions for the promotion of labour productivity. In order to promote this, the importance of evaluation of the performance is increasing; the right approach should be found to collaborate, to motivate employees, to develop a fair remuneration system, taking care of development, results and effectiveness of one's work (Raudeliūiene, Meidute-Kavaliauskiene, 2014). 


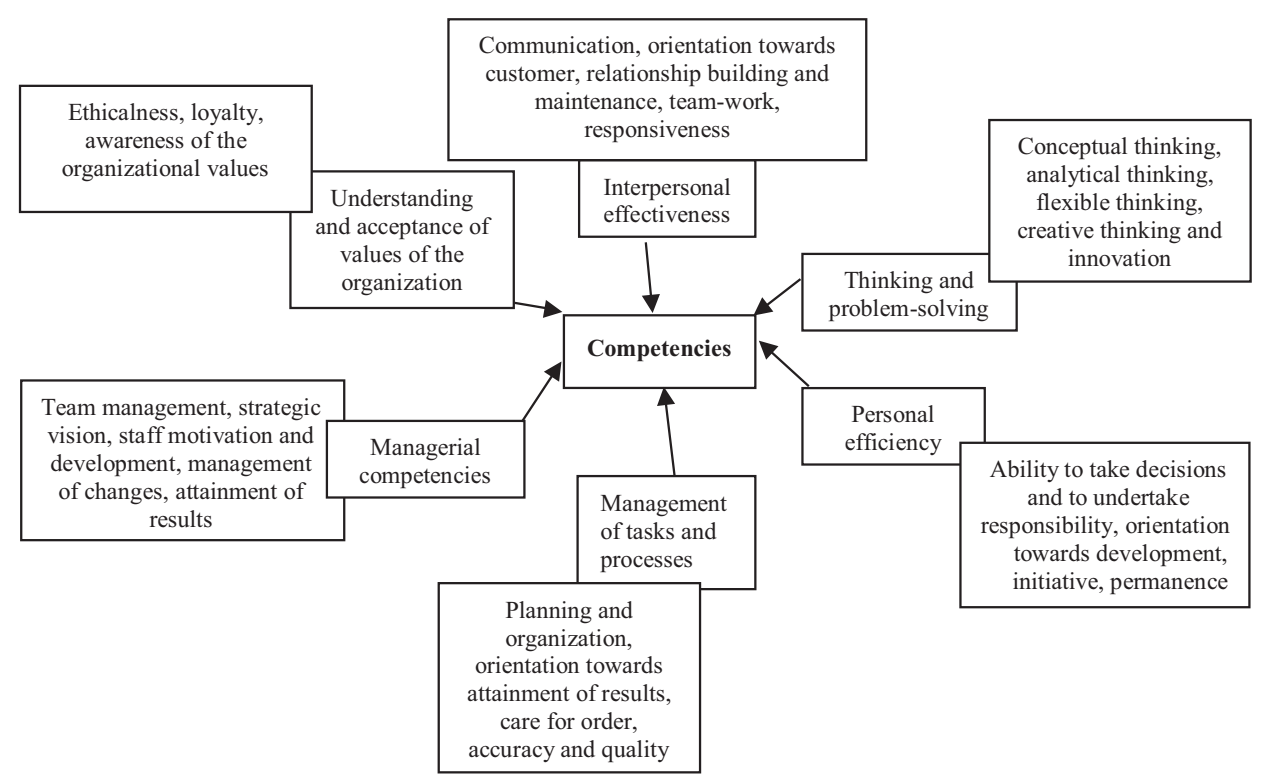

Source: created by authors, based on Kompetenču värdnīca, 2011

Fig. 1. Competencies of the performance evaluation

Training, level of professional experience, levels of professional knowledge and skills, general knowledge shall be assessed for professional qualifications of the employees. However, assessment of competence of the employees shall be based (Kompetenču vārdnīca, 2011) on six levels of the Competency Dictionary (see Figure 1), according to which the employee is evaluated by analysis of competency, knowledge and skills of the employee

The performance of official responsibilities shall be assessed based on the performance of official responsibilities as defined in the job description quality performance standards. Indeed, the objectives for implementation of the system are realistic and facilitate the job, effectiveness of its application and how positive are its results, is falling within the responsibility of each user. There are risks inherent in the course of any process. This applies also to evaluation of the employees. They may have a formal approach, with short and concise assessment, while placing emphasis on assessment, as well as an opportunity exists for a disproportionately high or low assessment. The evaluation process is valuable if it is approached with a sense of responsibility and a significantly greater time is devoted.

\section{EVALUATION PROCESS FOR EMPLOYEES}

The evaluation process NEVIS starts when the manager, at the beginning of the year, is nominating an overriding goal to be achieved during a certain time period (usually during one year). As a result, each employee is setting specific tasks 
that are planned to be accomplished during the year. The process of evaluating the work consists of the following stages:

1. Planning of work execution - determination of the goals to be achieved and tasks to be performed, agreement on the requirements for the fulfillment of the official duties;

2. Updating the performance of the work, at least once a year, reviews the performance of the work according to the requirements set for the post, the goals and tasks set and the status of execution;

3. Performance appraisal by performing performance analysis and evaluating the results and investment criteria;

4. Job Execution Assessment Negotiations, which take place when meeting the manager with the employee (New Assessment System for Public Administration Employees, 2012).

Less than a year later, each employee individually performs self-assessment of the accomplishments, knowledge, problems and competencies. All this shall be maintained and confirmed for the purpose that the direct manager can assess each employee individually. The direct manager shall evaluate the employee by filling out all the necessary fields in the system by placing an appropriate rating. Individual negotiations shall be carried out before or after approval of the assessment. The conduct of negotiations is optional because it takes a lot of time to negotiate the evaluation process and the job contribution with each employee individually. The employees shall have the right to express dissatisfaction concerning the evaluation process, and the process of re-evaluating options, to conduct and to negotiate with members of the commission in order to resolve uncertain problems in the evaluation process. The attitude of employees towards the evaluation process tends to be negative because it is perceived as a burden. While employees are awarded cash bonuses after evaluation, it is easy for the manager to determine which employee is appropriate and which one is less inappropriate for the official position resulting from the evaluation process. However, the greatest shortcoming in the evaluation process is how objectively self-assessment and assessment of subordinates is performed. There is always a risk of disagreement, frustration and conflict as a result of subjective evaluation. Therefore, it is important that consultations be carried out after evaluation of the employees. According to information at the disposal of the HR management of the institutions, only about $25-30 \%$ of direct managers are negotiating the evaluation process. Both managers and subordinates are the initiators of negotiations. This is a relatively low indicator, given that the ministries work about 3300 thousand people (the public administration needs to change-the lower number of employees still does not improve the efficiency). Given that the managers do not organise individual negotiations with each employee, there may be several reasons: indifference, irresponsible attitude, reluctance, fear of discussing the evaluation process, workload. Electronic environmental features alienate people from interpersonal contacts and communication; therefore, it is 
important for the manager not to forget direct contacts and communication with the employees by improving labour relations and mutual trust.

The system is not remotely distanced from interpersonal communication and communication, but the assessment process creates stress, because the system is used at least twice a year, and people are experiencing problems in mastering the system. It also raises the problem of changing the password, rarely accepting a password, after the first entry. The easier the password, the more likely it will be when you accept it. As well as the self-assessment and evaluation process, there are limits to the number of words that restrict the text. As another negative feature can be mentioned, changes or additions made to the system should be kept on a regular basis if this is not done, the system will unload the user and everything must start with the new one. But in spite of these shortcomings, the employee can perform an assessment of the performance at any time, and the possibility of a third person having access to the evaluation results has diminished.

In order to clarify the process of evaluating the public administration employees, monitoring was carried out in the institutions "public administration 1 " and "public administration 2", through monitoring the process of evaluating employees using the NEVIS advantages and disadvantages. The evaluation process accords great importance to education and qualification of the employees and its regular development. In 2017 "public administration 1" employs 3\% staff with $\mathrm{PhD}$ degrees, while "public administration 2 " - 2\%, while in the "public administration 1" higher education has been obtained by $89 \%$ and in the "public administration 2" - 98\%. While in the "public administration 1", $8 \%$ of employees have secondary vocational education or general secondary education (see Table 1).

Table 1

Education acquired by the employees

\begin{tabular}{|c|c|c|c|}
\hline Institutions & PhD & $\begin{array}{c}\text { Higher Education (Bachelor } \\
\text { and Master Degrees) }\end{array}$ & $\begin{array}{c}\text { Secondary vocational } \\
\text { education }\end{array}$ \\
\hline “public administration 1" & $3 \%$ & $89 \%$ & $8 \%$ \\
\hline "public administration 2" & $2 \%$ & $98 \%$ & - \\
\hline
\end{tabular}

Source: created by authors

In order to ensure successful compliance with the assignments, in 2016, the institution's employees participated in the qualification and the professional knowledge improvement activities (courses, seminars, etc.), such as the institution "public administration 1" has attended education establishments around 207 times, while in the institution "public administration 2" - 454 times. In the light of the School of Public Administration (hereinafter referred to as SPA) data in 2016, the number of training services has increased (see Figure 2) since 2009. Taking into account the fact that from 2008-2010 Latvia was hit by the financial crisis, the budget was not invested in education of employees. Therefore, 
from 2008 to 2009, the study visit has slowed down, which has been gradually increasing since 2009. Increasingly, there is a growing emphasis on educating and improving the skills of employees in order to have skilled and knowledgeable specialists working in the public administration.

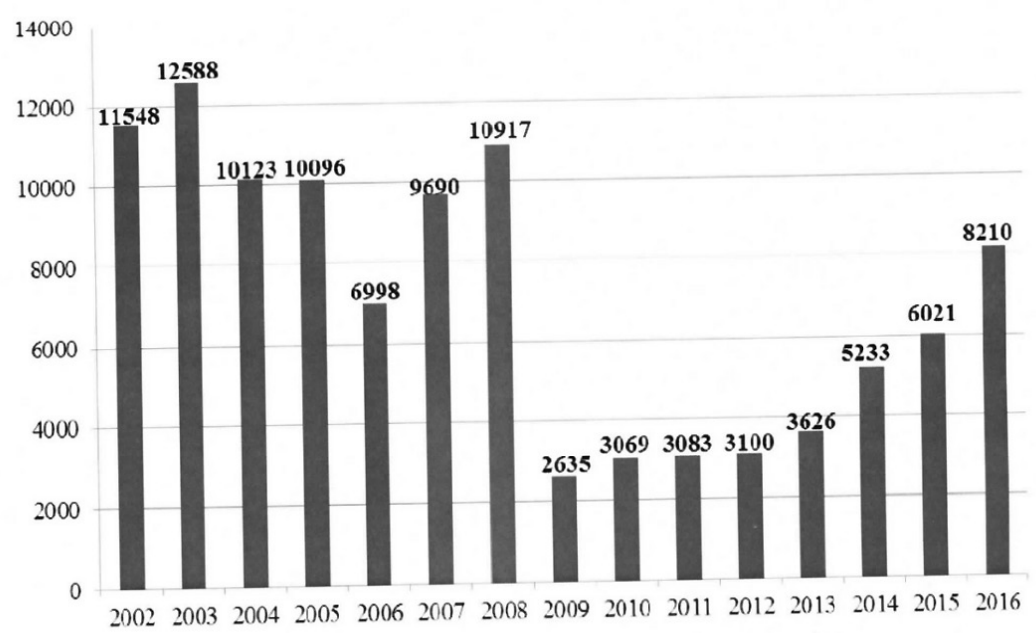

Source: Valsts Administrācijas skola, 2016

Fig. 2. Number of participants of basic studies at SPA

SPA offers public administration courses and seminars to all those employed by public administration through identification of training needs, after evaluating the performance on an individual basis. There is a comprehensive selection of courses and seminars - around 157 training courses according to expectations and requirements. In the training process, it is important that the employee obtain useful knowledge and are able to apply the same during the work process. It is important that people would be focused on self-development and willingness to improve, by achieving a better performance. Motivated and satisfied employees are more interested in self-development because they are motivated to work qualitatively with a desire to attain their targets. Whilst, unmotivated people are more passive, hence there is a chance that a few of them are indifferent towards the development of knowledge. Attendance of training institutions is more as a responsibility of each employee, particularly if compulsory training is not attended, which is organised within the framework of the institution. The manager should take an interest whether employees are attending both recommended and compulsory training, after which it is possible to determine whether an employee is interested in working and developing additional knowledge, skills and competencies according to their position. It is very important that the knowledge acquired in the learning process is applied practically and that the training received 
is of substantial content, interesting and up-to-date. The knowledge acquired in the process of evaluating the work and its usefulness can not be estimated only by the fact that the employee has received the certificate. A worker can obtain several certificates a year, but if the acquired knowledge and competences can not be applied in practice, then the results of the work will not improve. And it can be concluded that the performance of a job depends more on the employee's own responsibility and the desire to improve his skills and competences. But the manager must be motivated to learn from. As a result, performance measurement is a complex process based on subjective opinion and formal discovery. Therefore, those responsible for the human resources of the public administration must explain the purpose, purpose and purpose of the assessment system and the functions and possibilities of using the system. Managers and employees have to change the attitude to the evaluation process without perceiving evaluation as a formal process. Employees need to create an understanding of the functioning of the evaluation system in order for the employee to be able to use the system, why it is necessary to make an assessment and professional development results. As well, the manager should ensure a feedback by maintaining communication and building mutual trust. In principle, public administrations should keep track of the education they receive from their staff, so that high-level positions are taken up by educated and knowledgeable professionals. The purpose of using the performance measurement system is considered incomplete in order to be in line with the goal set for effective use of human resources in public administration, it is necessary to eliminate all identified factors and attitudes from the manager and employees.

\section{CONCLUSIONS, PROPOSALS, RECOMMENDATIONS}

Based on the analysis of the literature and the research carried out, the authors conclude:

1. The evaluation process allows for the assessment of staff achievements and errors occurred in the work process, determination whether the objective pursued has been achieved and what work is contributed in taking care of the professional growth and development of the institution's employees, improvement of mutual communication and contacts, adjusting remuneration changes, providing training for the employees, and by reducing staff turnover as far as possible.

2. In the evaluation process, it is important to assess performance, training needs, and growth opportunities of the subordinates during a certain time period, by involving specialists, if necessary.

3. The need for attending courses for the employees shall be determined after assessment, by evaluating what competences need to be improved. Therefore, negotiations have an important role to play in the evaluation process where it is possible to suggest what competencies need to be improved. Negotiations 
should be aimed at improving motivation and satisfaction, understanding, mutual collaboration, understanding of employees of the institutional goals, and their role in achieving it by improving the performance process.

The following proposals have been suggested in course of the work:

1. The managers and the HR management of the institutions should follow the training and attendance thereof the employees, setting out a compulsory attendance of training related to the official position, and to motivate the learning of new knowledge in order to improve the quality of work.

2. Each year, the HR management of the institution must verify statistically the attendance of training of the employees and in course of the evaluation process has to evaluate the benefits of training and the performance through evaluation of the benefits of training.

\section{REFERENCES}

Alvesson, M. (2004a). Knowledge Work and Knowledge - Intensive Firms. Oxford: Oxford university press, pp. 271.

Armstrong, M. (2004b). How to be an even better manager. A complete A-Z of proven techniques \& essential skills. Kogan Page, pp. 299.

Armstrong, M. (2007). Hanbook of Employee Reward Management and Practice. London; Philadelphia: Kogan Page, pp. 491.

Armstrong, M. (2009). Armstrong's Handbook, of Human Resource Management Practice (11th Edition). Kogan Page, London and Philadelphia, pp. 1063.

Kompetenču vārdnīca (2011). Retrieved from: https://www.mk.gov.lv/sites/default/ files/editor/kompetencu_vardnica.pdf_1.pdf.

Covey, S. R. (2013). The 7 habits of highly effective people: powerful lessons in personal change. 25th anniversary edition / with a foreword by Jim Collins. New York: Simon \& Schuster, pp. 391.

Dombrovska, L. R. (2009). Cilvēkresursu kapitāla vadība. Rìga: Zvaigzne ABC, p. 212.

Ešenvalde, I. (2008). Personāla vadības mūsdienu metodes. Rīga: Merkūrijs LAT, p. 349.

Jauna novērtēšanas sistēma valsts pārvaldē strādājošajiem, (2012). Retrieved from: https://lvportals.lv/skaidrojumi/250038-jauna-novertesanas-sistema-valstsparvalde-stradajosajiem-2012.

Latham, G. P., Wexley, K. N. (1977). Behavioral observation scales for performance appraisal purposes. Personnel Psychology, 30, 255-268.

Valsts Administrācijas skola, (2016, 2015). Retrieved from: http://www.vas.gov.lv/lv/ jaunumi?\&start $=1$.

Senge, P. M. (1997). The Fifth Discipline. Great Britain: century Business, pp. 424.

Spencer, L. M., Spencer, S. M. (1993). Competence at work: models for superior performance. Wiley, pp. 372.

Valsts pārvaldei jāmainās - mazāks darbinieku skaits efektivitāti vēl necels (2017). Retrieved from: https://lvportals.lv/viedokli/292216-valsts-parvaldei-jamainasmazaks-darbinieku-skaits-efektivitati-vel-necels-2017.

Raudeliūiene, J., Meidute-Kavaliauskiene, I. (2014). Analysis of factors motivating human resources in public sector. ScienceDirect, pp. 720. 


\section{THE AUTHORS}

Laura Keršule, Mg. sc. admin. Her research interests are regarding employee motivation, employee engagement, company reputation and social responsibility. Her scientific publications cover on company reputation influencing aspects, commitment in work-place, employee motivation, employee engagement and social responsibility. There have been presentations about research results in various international scientific conferences in Latvia, Italy, Russia, Lithuania and Estonia. The research results are published in internationally reviewed scientific issues available also in data bases Web of Science and EBSCO. The research results are used in management of the company and non-governmental Association of Personnel Management of Latvia.

Laimdota Komare has a Master of Science degree in International Economics and Business (2017), University of Groningen. She has obtained Bachelor of Social Sciences in International Economics (2015), University of Latvia. Her interests in the field of economics include economic growth, international trade and development.

Kristīna Bojāre has a Master's degree in Economics in the field of finance. Currently a PhD student at the University of Latvia (LU) and part time lecturer at the LU Faculty of Economics and Management, Department of Finance and Accounting. She also works in the field of banking supervision with main tasks relating to bank specific risk management, internal governance. Fields of interests are bank supervision, bank individual and systemic risk assessment, prudential regulation of banks considering their systemic importance.

Kristine Petrovska has a Master's degree in Economics in the field of banking and finance. Currently a final year PhD student at the University of Latvia. She works in the field of national political decision making with main tasks related to consultation and analysis. Fields of research include banking, in specific banking crisis, systemic risk, financial derivatives and behavioural economics.

Diāna Arāja graduated from the Latvian Medical Academy (Master's Degree in Pharmacy), the University of Latvia (Master's Degree in Economics and Management) and the University Pompeu Fabra (International Master's Degree in Health Economics and Pharmacoeconomics). She has more than 15 years' experience in public administration and academia, specialising in pharmaceutical policy and legislation. She is the author of more than 30 scientific publications. 
Her scientific research is dedicated to health economics and pharmacoeconomics, health systems research and health technology assessment.

Jānis Priede, Dr. oec., professor at the University of Latvia, Faculty of Business, Management and Economics. Combines academic knowledge with extensive international experience and views. Has been visiting professor at many foreign universities - Columbia University in New York (US), Fulda University of Applied Sciences (Germany), Iceland University (Iceland), Warsaw School of Economics (Poland), Aveiro Univerat (Portugal), and nearby neighbouring universities at Tartu University (Estonia) and Kaunas University of Technology (Lithuania), as well as others. In 2016, won the University of Latvia Student Council Award for Professor of the Year.

Julia Liodorova is a $\mathrm{PhD}$ student at University of Latvia, certified forensic accountant. Has extensive academic and practice experience in the field of accountancy and forensic. She is the author of several practice articles to the Latvian accountants in regional journals and several scientific publications in the field of her research. Scientific interests: forensic accounting examination, its development and recognition; financial misstatements determination and "white-collar" crimes detection using modern techniques. Working on the $\mathrm{PhD}$ thesis. Her research is focused on bankruptcy fraud detection using prediction models.

Valeriya Fursofa is a final year student in a Bachelor degree in Accounting at the University of Latvia, Faculty of Business, Management and Economics, Department of Finance and Accounting. She mastered her experience in accounting in various areas of business, from data entry to annual reports. This study was her first step in the scientific field, during which she became interested in the profession of forensic accountant. She plans to continue research in the field of the forensic accounting and begin to study audit of fraud in the financial statements.

Zanda Davida, Mg. iur., is a doctoral student at the University of Latvia, Faculty of Law and a lecturer at the Turiba University (Latvia), Department of Law. Her research is focused on consumer and competition law. She is the author of several scientific publications. She has taken part as speaker in the several international conferences and worked as an expert in the European Commission working groups on consumer rights.

Ineta Lakstigala has a Masters's degree in Management Sciences, Riga Teacher Training and Educational Management Academy. She is a $\mathrm{PhD}$ student in management science. Since 2012, she has work public administration. Her main interests: competencies of public administration employees, employee development, leadership and leadership skills, human resources, relationship at work. 
Signe Balina obtained Doctor degree in Economics in 2002. At present, she is a Professor at the University of Latvia, Faculty of Economics and Management. Since 2009, Signe Balina has been a President of the Latvian Information and Communications Technology Association (LIKTA). Since 2010, Signe Balina has been a Chairperson of the Board of "IT Competence Centre" that promotes a long-term cooperation between ICT enterprises and science institutions in the fields of natural language technologies and business process analysis technologies. 

Journal of Economics and Management Research. Volume 7, 2018

LU Akadēmiskais apgāds Aspazijas bulv. 5, Riga, LV-1050 www.lu.lv/apgads 